\title{
Metabolic effects of growth hormone
}

Citation for published version (APA):

Hoos, M. B. (2003). Metabolic effects of growth hormone. [Doctoral Thesis, Maastricht University]. Universiteit Maastricht. https://doi.org/10.26481/dis.20030703mh

Document status and date:

Published: 01/01/2003

DOI:

10.26481/dis.20030703mh

Document Version:

Publisher's PDF, also known as Version of record

\section{Please check the document version of this publication:}

- A submitted manuscript is the version of the article upon submission and before peer-review. There can be important differences between the submitted version and the official published version of record.

People interested in the research are advised to contact the author for the final version of the publication, or visit the DOI to the publisher's website.

- The final author version and the galley proof are versions of the publication after peer review.

- The final published version features the final layout of the paper including the volume, issue and page numbers.

Link to publication

\footnotetext{
General rights rights.

- You may freely distribute the URL identifying the publication in the public portal. please follow below link for the End User Agreement:

www.umlib.nl/taverne-license

Take down policy

If you believe that this document breaches copyright please contact us at:

repository@maastrichtuniversity.nl

providing details and we will investigate your claim.
}

Copyright and moral rights for the publications made accessible in the public portal are retained by the authors and/or other copyright owners and it is a condition of accessing publications that users recognise and abide by the legal requirements associated with these

- Users may download and print one copy of any publication from the public portal for the purpose of private study or research.

- You may not further distribute the material or use it for any profit-making activity or commercial gain

If the publication is distributed under the terms of Article $25 \mathrm{fa}$ of the Dutch Copyright Act, indicated by the "Taverne" license above, 


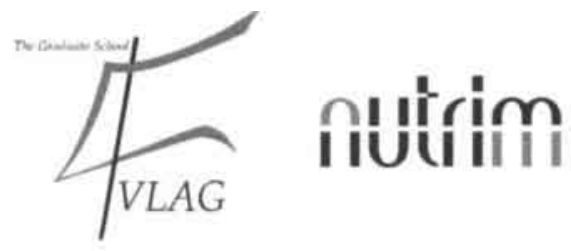

The study presented in this thesis is a research project of the department of pediatrics of the University hospital Maastricht and the University Maastricht and was performed at the Nutrition and Toxicology Research Institute Maastricht (NUTRIM) which participates in the Graduate School VLAG (Food technology, Agrobiotechnology, Nutrition and Health Sciences), accredited by the Royal Netherlands Academy of Arts and Sciences.

\section{Production}

Andi Drukwerkindustrie Geleen

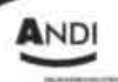

Cover

Fotografie: Hugo Thomassen

Model: Sem Cuypers

(c) Maria Benedikte Hoos, Maastricht 2003

ISBN 90-9017014-6 


\section{METABOLIC EFFECTS \\ OF GROWTH HORMONE}

\section{Proefschrift}

ter verkrijging van de graad van doctor aan de Universiteit Maastricht,

op gezag van de Rector Magnificus,

Prof. dr. A.C. Nieuwenhuijzen Kruseman

volgens het besluit van het College van Decanen

in het openbaar te verdedigen

op donderdag 3 juli 2003 om 16.00 uur

door

Maria Benedikte Hoos

Geboren te Moordrecht op 21 december 1973 


\section{Promotores}

Prof. dr. R.A.M.G. Donckerwoicke

Prof. dr. K.R. Westerterp

\section{Co-promotor}

Dr. W.J.M. Gerver

\section{Beoordelingscommissie}

Prof. dr. C.E. Blanco

Prof. dr. H.A. Delemarre-van de Waal (Vrije Universiteit Amsterdam)

Prof. dr. S.L.S. Drop (Erasmus Universiteit Rotterdam)

Prof. dr. H. Kuipers

Dr. N.C. Schaper

The studies described in this thesis were financially supported by Eli Lilly, the Netherlands. Financial support by the Dr. ir. van de Laar Stichting, Ferring B.V. and Nutricia Nederland B.V. for the publication of this thesis is gratefully acknowledged. 


\section{CONTENTS}

\section{CHAPTER 1}

Introduction

\section{CHAPTER 2}

Physical activity levels in children and adolescents

\section{CHAPTER 3}

Physical activity level measured by doubly labeled water and accelerometry in children

\section{CHAPTER 4}

Physical activity pattern of children assessed

by tri-axial accelerometry

\section{CHAPTER 5}

Physical activity in children receiving growth hormone therapy as measured by tri-axial accelerometry

\section{CHAPTER 6}

Endurance time and grip strength in children receiving growth hormone therapy

\section{CHAPTER 7}

Short-term effects of growth hormone on

body composition as a predictor of growth

\section{CHAPTER 8}

Discussion

Summary

Samenvatting

Dankwoord

Curriculum vitae 

CHAPTER 1

INTRODUCTION 
GROWTH AND GROWTH HORMONE 6

$\begin{array}{ll}\text { Normal growth } & 6\end{array}$

Regulation of growth hormone secretion $\quad 7$

Regulation of growth by the pituitary: the somatomedin hypothesis $\quad 8$

DIAGNOSING GROWTH HORMONE DEFICIENCY

Growth hormone secretion in the diagnosis of growth hormone deficiency

Evaluation of the arginine stimulation test at the department

of Pediatrics University Maastricht

Prediction of the effect of $\mathrm{GH}$ therapy on growth

\section{METABOLIC PREDICTORS FOR THE EFFECT}

OF GROWTH HORMONE ON GROWTH

Physical activity

Effects of growth hormone on energy expenditure

and physical activity related energy expenditure

Body composition

Effects of growth hormone on body composition and physical fitness 


\section{GENERAL INTRODUCTION}

Human growth follows a narrow, genetically defined path. Any deviation on its way to adolescence must be regarded as a consequence of any interference with the child's general health. It is therefore important to watch a child's growth pattern. Although there are many well-known circumstances with a negative effect on growth, the underlying pathophysiology remains largely unknown. Even more elusive are the mechanisms that result in catch-up growth after repair of the failure.

The main hormonal cause of growth retardation, insufficient growth hormone (GH) secretion, was treated for the first time in 1958 (1). Because the $\mathrm{GH}$ administered was extracted from human cadavers, its supply was limited and only patients with proven severe growth hormone deficiency (GHD) had access to this treatment. The diagnostic criteria used were severe retarded growth and serum peak $\mathrm{GH}$ concentrations after stimulation not exceeding $9 \mathrm{mU} / \mathrm{I}$. Problems arose in 1984, when a 20-year-old man, who had started GH treatment before the age of 3 years, died of Creutzfeldt-Jakob disease (2) 17 years later.

Creutzfeldt-Jakob disease is a degenerative neurological disease, which is transmissible by contact with abnormal prions that are located within the central nervous system of affected subjects. Because Creutzfeldt-Jakob disease is an unusual disease in a patient aged 20 , it did not take long before the link between contamination by the supplied pituitary $\mathrm{GH}$ and Creutzfeldt-Jakob disease was made. After the discovery of another two cases, treatments with human $\mathrm{GH}$ were stopped on April 19, 1985 (2).

Several months later, the already developed technique to produce growth hormone by means of recombinant DNA was approved by the Food and Drug Administration (FDA). Because the supply of $\mathrm{GH}$ was now (technically) unlimited, therapy was no longer restricted to severely growth hormone deficient children. Partially growth hormone deficient patients, who did not meet the earlier strict criteria, also became eligible for treatment and often showed a positive, though unpredictable, response to therapy. This unpredictability has led to extensive discussions. There is ongoing debate about the value of endocrine testing, in which $\mathrm{GH}$ concentrations are measured in serum, as a method to distinguish $\mathrm{GH}$ deficient children from those whose stunted growth is based on other factors. Nevertheless, these endocrine tests are still being applied, because other methods to predict the effect of therapy are almost not available.

The incentive to start the present study was to find out if short-term metabolic changes induced by growth hormone therapy would be able to predict the long-term effect of growth hormone on growth. The study was focused on two effects of GH on metabolism. First, it is a common experience among doctors and parents that growth hormone deficient children become livelier and more active after the introduction of $\mathrm{GH}$ therapy. Secondly, there is increasing evidence in the literature about the changes in body composition caused by $\mathrm{GH}$.

Both of these metabolic effects, which appear after a brief period of $\mathrm{GH}$ treatment, might be used as predictors for the long-term growth effect. 


\section{GROWTH AND GROWTH HORMONE}

\section{Normal growth}

Evaluating a child's growth requires reference data for children matched for age, race and sex. Several sets of reference data are available for the Dutch population (3-6).

A standard growth chart can be derived from a data set in two steps. First, the $50^{\text {th }}$ centile is constructed by drawing a smooth curve, usually by a least squares approximation, through the whole data set. Subsequently, the age specific standard distributions must be estimated by dividing the population into age groups and calculating the mean and standard deviation (SD) for each of them. A smoothed line connects the obtained SD values and represents the standard deviation for the whole population. This approach requires the population to be normally distributed. In the case of a skewed distribution, several methods can be applied, the most common of which is a transformation of the data set into a symmetric Gaussian distribution. Gerver and de Bruin applied a method in which the population is divided into a group above and a group below the $50^{\text {th }}$ centile (5). Assuming these groups to be normally distributed, they calculated the standard deviation for each group.

Instead of standard deviations, percentiles can be used. Percentiles simply rank the members of the population by height, thus reflecting the height distribution within the population. They are not hampered by a skewed distribution. $A$ height that equals $P_{10}$ (the $10^{\text {th }}$ percentile) implies that the child belongs to the $10 \%$ smallest children in that population. The calculation of percentiles can be used to obtain the values of $P_{25}, P_{50}$ and $P_{75}$ from moderate sample sizes. Estimation of the third and $97^{\text {th }}$ percentiles, however, requires extremely large sample sizes. Therefore, percentiles are often derived from the standard deviations, where +2 SDS equals the $97.7^{\text {th }}$ centile, and -2 SDS the $2.3^{\text {th }}$ centile. It must be realized that percentiles derived from SDS have lost their original meaning.

When evaluating a child's growth, three items have to be taken into consideration: height, height velocity and the target height. The child's height is evaluated relative to that of the reference population. The height measurement is plotted on the growth chart or expressed as standard deviation score (SDS):

$$
\operatorname{SDS}_{\mathrm{t}}=\left(\mathrm{x}_{\mathrm{t}}-\mu_{\mathrm{t}}\right) / \sigma_{\mathrm{t}}
$$

where $x_{t}$ denotes height score at age $t, \mu_{t}$ the population mean at age $e_{t}$ and $\sigma_{t}$ the SD of the reference population at age $t$. A SDS outside 2 SDS is considered to be beyond the normal range. Secondly, besides the actual height of a child, one needs to be informed about its growth. At least two measurements are necessary to calculate the height velocity. In children beyond the age of one year, an interval of at least three months is necessary for an accurate interpretation of their growth. A difference in height velocity of more than 0.25 SDS in one year is regarded as outside the normal range. 
The target height is an approximation of the child's expected height as an adult, in view of its genetic potential. The target height is calculated by taking the height of the father (reduced for girls by the male-female difference in the adult population) and that of the mother (increased for boys by the male-female difference in the adult population) divided by two, plus an increment correcting for the secular trend. The target height can also be calculated in terms of SDS as: height SDS of the father + height SDS of the mother, divided by two. When comparing the target height with the child's actual height, a difference of more than 1.3 SDS (or $8.5 \mathrm{~cm}$ ) for Dutch children is regarded as abnormal. In this case, the child's height does not correspond to its genetic potential (7). The growth chart shows whether a child's growth is within the normal range. If growth is found to be outside the normal range, diagnostics have to be applied.

\section{Regulation of growth hormone secretion}

The growth-promoting substance from the pituitary gland was first isolated in cows as bovine growth hormone in $1944(8,9)$, and afterwards in humans as human $\mathrm{GH}$, around $1956(10,11)$. Growth hormone is a single-chain polypeptide consisting of 191 amino acids and secreted by somatotrophic cells in the anterior pituitary. Some $70-75 \%$ of the growth hormone circulates in the blood as a $22 \mathrm{kDa}$ molecule, while the second largest fraction of the circulating $\mathrm{GH}$ pool consists of a $20 \mathrm{kDA}$ form (12). Several mechanisms cause the heterogeneity of $\mathrm{GH}$ in serum. Chromosome 17 includes two $\mathrm{GH}$ genes, termed hGH-N (for normal) and hGH-V (for variant). The two corresponding proteins are highly homologous and differ by 13 of the 191 amino acids. The hGH-N gene is expressed in the pituitary gland, the hGH-V gene primarily in the placenta $(13,14)$. Transcripts of the hGH$\mathrm{N}$ gene are spliced into two different mRNAs, creating the $20 \mathrm{kDa}$ and $22 \mathrm{kDa}$ forms (15).

Additional variation is caused at the post-translational level by modifications of monomeric forms, as well as oligomerization. The binding of $\mathrm{GH}$ to binding proteins (GHBP) in the circulation creates extra complexity. Finally, metabolic products such as proteolytic fragments of $\mathrm{GH}$ contribute to the variety of $\mathrm{GH}$ forms (16).

The secretion of $\mathrm{GH}$ by the anterior pituitary is pulsatile and controlled by two neurohormones, which are produced by the hypothalamus and continually influence the secretory rate of $\mathrm{GH}$. GH secretion is stimulated by the $\mathrm{GH}$ releasing hormone $(\mathrm{GHRH})(17$, 18). In contrast, somatostatin, also called $\mathrm{GH}$ inhibiting hormone $(\mathrm{GHIH})$, inhibits $\mathrm{GH}$ secretion (19). Pulses of $\mathrm{GH}$ secretion occur at times of maximum GHRH and minimum GHIH secretion $(20,21)$. Tonic GHIH secretion is important for maintaining low basal GH levels.

In addition to GHRH and $\mathrm{GHIH}, \mathrm{GH}$ release is also influenced by free fatty acids, leptin. neuropeptide- $Y$ and ghrelin $(22,23)$. Free fatty acids act directly on the pituitary to inhibit $\mathrm{GH}$ release. Because $\mathrm{GH}$ stimulates lipid mobilization, this is hypothesized to constitute a feedback loop $(24,25)$. Leptin stimulates $\mathrm{GH}$ release from the hypothalamus by regulating GHRH and GHIH activity (26-28). The effect of leptin may also involve neuropeptide-Y (NPY), since leptin suppresses NPY expression and infusion of NPY is known to suppress 
$\mathrm{GH}$ secretion $(29,30)$. Ghrelin appears to be a more potent inducer of $\mathrm{GH}$ release than GHRH and exhibits a synergistic effect with GHRH $(31,32)$. It is predominantly produced by the stomach (33-35) but has also been found in lower amounts in the intestine (33), pituitary (36), kidney (37), placenta (38) and hypothalamus (35), GH itself also acts on the hypothalamus to affect its own secretion.

Insulin-like growth factor-I (IGF-I or somatomedin), a mediator of the effects of GH on tissues, influences the secretion of $\mathrm{GH}$ by binding to specific receptors in the pituitary and suppressing $\mathrm{GH}$ gene transcription and $\mathrm{GH}$ secretion $(39,40)$. IGF-I circulates in the blood either as a free molecule ( $\mathrm{t}_{1 / 2}$ is about 15-20 minutes) or bound to specific high affinity binding proteins that prolong the half-life of the peptide $(41,42)$ by protecting it from proteolytic degradation. So far, six IGF-I binding proteins (IGFBPs) have been identified. The circulating IGFBPS act as carrier proteins and regulate the availability of IGF-I at its receptor in target tissues (43). Specific proteases are necessary to cleave IGF-I from its binding protein complex (41). The major circulating form of IGF-I is a high molecular weight complex consisting of IGF, IGFBP-3 and ALS (acid-labile subunit) (44). The release of IGF from this large complex leads to the formation of smaller complexes with other IGFBPs, which are believed to transport IGFs out of the circulation. Most target tissues express IGFBPs that regulate the local action of IGFs.

$\mathrm{GH}$ also circulates in plasma attached to a specific, low capacity binding protein (GHBP) $(45-47)$, which is homologous to the cleaved extracellular domain of the $\mathrm{GH}$ receptor (48, 49). $\mathrm{GH}$ binds with high affinity to its receptor, which is found in tissues throughout the body. The molecule exhibits two binding sites for the $\mathrm{GH}$ receptor, causing dimerization of the receptor. This step is required for biological activity of the hormone (50).

\section{Regulation of growth by the pituitary: the somatomedin hypothesis}

The somatomedin hypothesis explains the regulation of somatic growth by the pituitary. According to the original somatomedin hypothesis (1950s), GH was thought to stimulate IGF-I synthesis and release from the liver. IGF-I was believed to reach the main target organs such as cartilage and bones via the circulation and to act as an endocrine agent. Circulating IGF-I was also thought to have a feedback effect, because it was supposed to suppress the further release of $\mathrm{GH}$ from the pituitary (51).

This hypothesis was first challenged by the discovery of local IGF-I and IGF-II production in most, if not all tissues. This strongly suggested an autocrine/paracrine effect of IGF-I (5254). According to the alternative somatomedin hypothesis, both circulating and locally produced IGF-I are responsible for the effects of $\mathrm{GH}$. In addition, the possibility that $\mathrm{GH}$ may have IGF-I independent effects on tissues could not be excluded $(22,23)$.

In 1985, Green et al (55) proposed the 'dual effector theory' to explain the roles of $\mathrm{GH}$ and IGF-I in growth and differentiation. This theory suggests that $\mathrm{GH}$ stimulates the differentiation of adipocytes and that IGF-I stimulates further expansion (55). Isaksson extended the dual effector theory to the growth plate, by proposing that $\mathrm{GH}$ acts directly at the germinal zone to stimulate the differentiation of chondrocytes. Furthermore, $\mathrm{GH}$ 
enhances the local production of IGF-I, which in turn stimulates the expansion of chondrocytes in an autocrine/paracrine manner $(56,57)$.

Gene targeting technologies in rodents have provided further insight into the GH-IGF axis. IGF-I proved to have prenatal as well as postnatal significance, in contrast to IGF-II, which is only important during prenatal stages (58). Isaksson (59) et al. showed that inactivation of liver-produced IGF-I results in increased serum levels of insulin, leptin and cholesterol, a state of insulin resistance and eventually a decrease in fat mass. These findings show that endocrine IGF-1 is not required for post-natal growth, but is important for the regulation of carbohydrate and lipid metabolism $(59,60)$. In contrast, the autocrine/paracrine IGF-I production is sufficient for normal growth and development, although a direct effect of $\mathrm{GH}$ on non-hepatic tissues cannot be excluded (60).

\section{DIAGNOSING GROWTH HORMONE DEFICIENCY}

\section{Growth hormone secretion in the diagnosis of growth hormone deficiency}

The Dutch Growth Foundation (Nederlands Groeistichting, NGS) regulates the prescription of $\mathrm{GH}$ therapy in the Netherlands. Before approval to start GH therapy is given, the following criteria have to be met $(61,62)$ :

- exclusion of other causes of growth retardation than GH deficiency:

- height below -2.5 SDS;

- a decrease in height of more than 0.25 SDS over at least one year:

- retarded skeletal maturation (>1SD);

- decreased or below-normal IGF-I levels;

- maximum GH concentration in two endocrine provocation tests not exceeding $20 \mathrm{mU} / \mathrm{I}$.

Although several problems arise in the use of endocrine tests to estimate insufficient growth hormone secretion, the outcome of such tests is still the essential (if not the only) element in the decision to start GH therapy (63).

Pituitary secretion of $\mathrm{GH}$ from somatotrophic cells is pulsatile, with the most consistent peaks occurring during phases 3 and 4 of sleep (64). Between these pulses, GH concentration may drop to very low levels. This is the reason why random blood samples give very little information about a child's GH secretory status. The best indication of growth hormone secretion status is obtained from the pattern of $\mathrm{GH}$ release during 24 hour sampling, but this is hardly feasible.

Hence, a child's GH production is usually evaluated by means of provocation tests. However, there are several reasons why the value of endocrine tests for evaluating GH 
secretion is still a subject of debate $(63,65-69)$. First of all, any stimulation by drugs does not represent the normal secretory dynamics (70). Secondly, there are important differences in the way the various stimulating drugs influence $\mathrm{GH}$ concentration. Clonidine, for example, induces $\mathrm{GH}$ release via central $\alpha$-adrenergic effects, while arginine increases $\mathrm{GH}$ secretion by inhibition of $\mathrm{GHIH}$ release.

Thirdly, and even more importantly, there are differences in the measurements of $\mathrm{GH}$ concentrations in serum, which relate to the existence of several forms of $\mathrm{GH}$ in the blood. Different assays may recognize $\mathrm{GH}$ isoforms to varying degrees, making results of different assays and laboratories hard to compare (16).

Last but not least, other factors influencing $\mathrm{GH}$ secretion, like stress, age, puberty, obesity and emotional deprivation, may also affect the diagnosis (70).

There exists international agreement that peak $\mathrm{GH}$ concentrations, whether spontaneous or by provocation, exceed $20 \mathrm{mU} / \mathrm{l}$ in normally growing children. At the same time, the above arguments, as well as the knowledge that endocrine tests are used differently (63) by different centres and that different laboratories make use of different assays, mean that it is virtually impossible to define a general cut-off value to distinguish normal from abnormal $\mathrm{GH}$ production.

To settle at least one point of debate, a harmonization factor has been introduced in the Netherlands to rectify the differences in the measurement of $\mathrm{GH}$ concentrations in serum. In 2001 the Section Endocrinology (LWBA=landelijke werkgroep bindingsanalyse) of the Dutch Foundation for Quality Assessment in Clinical Laboratories (SKZL=Stichting Kwaliteitsbewaking Ziekenhuis Laboratoria) initiated the harmonization of the growth hormone assays in the Netherlands.

Each laboratory has received a harmonization sample with an attributed $\mathrm{GH}$ concentration. This sample has been proven to be commutable for all used assays in the Netherlands, which means that there is no interference between sample and method. The measured value is used to establish a harmonization factor in laboratories, which makes the measured concentration equal to the attributed concentration. Pediatricians are obliged to report only harmonized $\mathrm{GH}$ concentrations when submitting test results to the Dutch Growth Foundation. This makes measured $\mathrm{GH}$ concentrations comparable within all pediatric centers of the Netherlands. Since 2003, all laboratories in the Netherlands are obliged by the LWBA to use the harmonization factor.

\section{Evaluation of the arginine stimulation test at the department of Pediatrics University hospital Maastricht}

To enforce the basic assumption of the present thesis of endocrine tests being ineffective for the prediction of the effect of $\mathrm{GH}$ on growth, the use of the arginine test was evaluated in 26 children previously treated with $\mathrm{GH}$ at the department of Pediatrics, University Hospital Maastricht. Growth retardation was defined on the basis of one of the following anthropometric criteria: 
- height below -2.5 SDS;

- change in height SDS of more than -0.25 SDS in one year;

- height below -1.3 SDS of the target height (7).

If other reasons than those related to $\mathrm{GH}$ for growth retardation were present, children were excluded.

All children had undergone an arginine growth hormone stimulation test because of suspected growth retardation based on one of the above anthropometric criteria. Change in height SDS after one year of therapy was taken as effect parameter. A mean change of 0.7 SDS during the first year of therapy was considered to be a good reaction on $\mathrm{GH}$ therapy, being the mean value found in the international KIGS study (71).

The decision to start growth hormone therapy was not based on the result of the arginine test only. Some of the patients had entered therapy despite a growth hormone response exceeding $20 \mathrm{mU} / \mathrm{l}$, because they met selection criteria based on anthropometric data.

Figure 1a shows the change in height SDS over 1 year against the maximum GH concentration found during the arginine tests. Assuming two borderlines: a maximum GH concentration found during the arginine test of $20 \mathrm{mU} / \mathrm{l}$ on the $\mathrm{x}$-axis and a change in height SDS after one year of therapy of 0.7 SDS on the $y$-axis, four quadrants are visible in the chart. The arginine test would be a very good predictor for the effect of GH therapy if

\section{Figure 1a}

Maximum growth hormone concentration found during the arginine test by growth in the first year of therapy. The reference lines indicate a change in height of 0.7 SDS and a growth hormone concentration of $20 \mathrm{mU} / \mathrm{l}$.

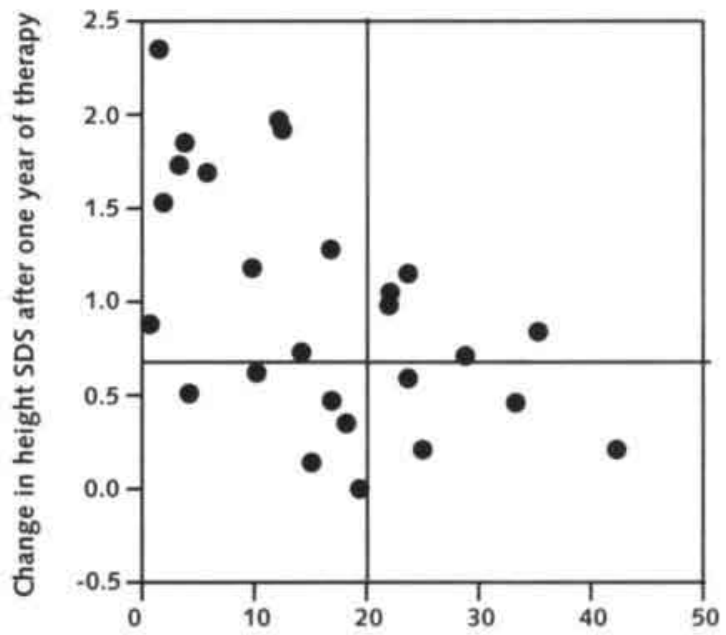

Maximum $\mathrm{GH}$ concentration arginine test ( $\mathrm{mU} / \mathrm{I})$ 
all children were positioned in the upper left quadrant (good growth response and low $\mathrm{GH}$ concentrations) or the lower right quadrant (poor growth response and high $\mathrm{GH}$ concentrations). However, only 15 out of 26 children $(57 \%)$ are situated in these two quadrants.

Figure $1 \mathrm{~b}$ shows the relation between the change in height SDS after one year of therapy and the height before therapy, on the $x$-axis a borderline of -2.5 SDS is indicated. For this parameter 18 out of 26 children $(69 \%)$ were situated in the upper left and lower right quadrant. According to this data, the arginine test is no better predictor for the growth effect of GH therapy than the height SDS before the start of therapy.

At present, many countries require two endocrine tests showing low $\mathrm{GH}$ levels before a patient becomes eligible for $\mathrm{GH}$ treatment. When comparing the maximum $\mathrm{GH}$ concentration found during an arginine test to those values obtained after provocation with clonidine in the same patients, it appeared that the diagnosis depends heavily on the test which has been performed. Figure $1 \mathrm{c}$ shows the maximum $\mathrm{GH}$ concentrations found during both tests. The indication of the $\mathrm{GH}$ concentration of $20 \mathrm{mU} / \mathrm{l}$ divides the figure into four compartments. If both tests agreed, all children should have been situated in the lower left or upper right quadrant. However, only $45 \%$ of the patients were located in these quadrants. Also this example confirms the problems related to the use of endocrine tests as described above and the need for another approach.

\section{Figure 1b}

Height at start of therapy plotted against growth in the first year of therapy. The reference lines indicate a change in height of 0.7 SDS and a height of -2.5 SDS.

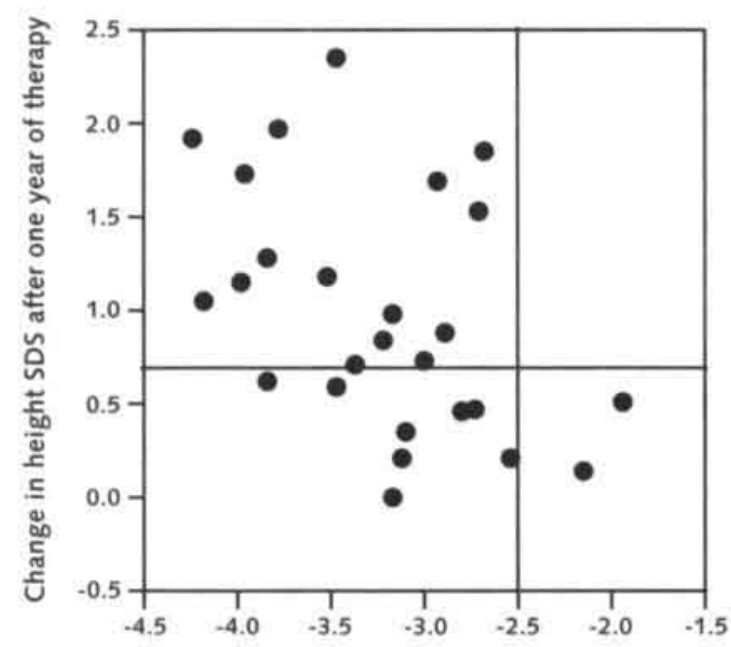

Height SDS before therapy 


\section{Figure 1c}

Maximum GH concentration of the clonidine test related to the maximum concentration of the arginine test.

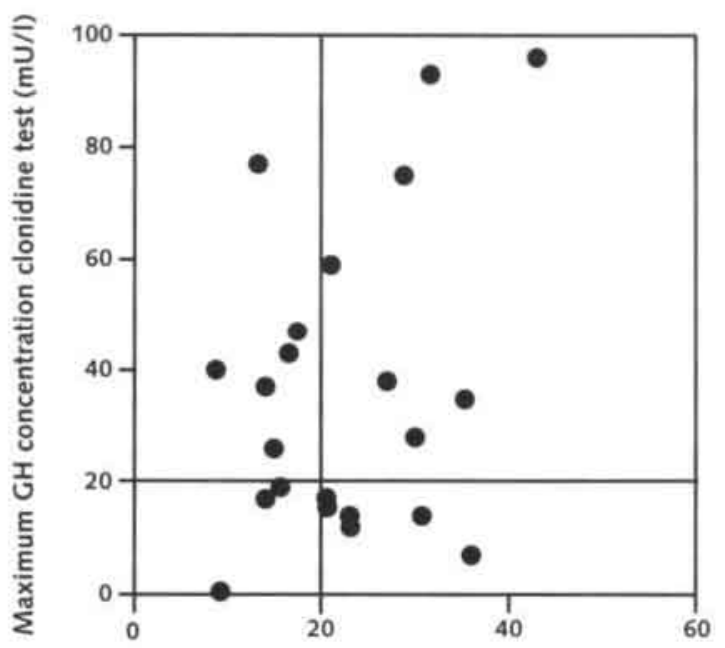

Maximum GH concentration arginine test ( $\mathrm{mU} / \mathrm{I})$

\section{Prediction of the effect of GH therapy on growth}

While in severe GHD, GH therapy may be expected to be effective in terms of growth response, the outcome of the therapy in partial GHD is hard to predict. Growth prediction models combine a selection of diagnostic variables to predict the longitudinal growth response of a child to $\mathrm{GH}$ therapy. Models can be based on pre-treatment variables, early effect variables, or both. The efficacy of a prediction model depends on its sensitivity and specificity. If the most important aim is to detect patients who will not respond to treatment, the model needs to have a high specificity, since specificity indicates the proportion of patients who are predicted to be non-responding and do indeed not respond. In contrast, a test with a high sensitivity correctly detects a high proportion of responders.

Most models presented in literature are based on baseline variables (71-78), although models based on effect parameters have also been described $(73,79-83)$. The number of parameters included ranges from $1(80)$ to $6(71)$. Such parameters include age (bone age or chronological age), anthropometric parameters (height SDS before treatment, target height SDS), outcome of endocrine tests and bone markers (alkaline phosphatase). Effect parameter models often include the height velocity or the change in height during the first 3 months of therapy. The correlation coefficient of the models with the height velocity ranges from 0.20 to 0.61 . An exception is the recently described "Cologne model" (79). This model is based on pretreatment bone age retardation as a fraction of chronological 
age, pretreatment serum levels of IGF-I, urinary levels of deoxypyridinoline (a bone resorption marker) after 1 month of treatment and height velocity after 3 months of treatment. The regression equation of this model explains $89 \%$ of the first-year growth variation.

\section{METABOLIC PREDICTORS FOR THE EFFECT OF GROWTH HORMONE ON GROWTH}

\section{Physical activity}

Physical activity and physical fitness are important for health. Inactivity increases the risk of diseases, like coronary artery disease (84) hypertension (85) and diabetes mellitus (86). Physical inactivity in childhood has been found to continue into adulthood (87), so the promotion of regular physical activity in children could serve as a preventive health strategy. Bringing about changes in habitual lifestyles, however, requires an understanding of the current levels and patterns of physical activity. Physical activity is an important determinant of the total daily energy expenditure (TDEE), which can be divided into four components:

- basal metabolic rate (BMR);

- diet induced thermogenesis (DIT):

- energy cost for growth;

- activity related energy expenditure (AEE).

BMR is the energy needed to maintain all vital body functions. This component can be divided into sleeping metabolic rate (SMR) and the energy costs of waking up (arousal). The second component of total daily energy expenditure is diet-induced thermogenesis, the energy expenditure associated with the digestion of food. This constitutes about $10 \%$ of energy intake and thus contributes $10 \%$ to TDEE when intake matches energy expenditure (88).

The energy needed to build up new tissues and the energy stored in the tissues are the energy costs for growth. The final component, AEE, is the most variable component, ranging from 25 to $35 \%$ of TDEE (88).

The 'gold standard' to measure TDEE is the doubly labeled water method, a method which makes use of the stable isotopes ${ }^{2} \mathrm{H}$ and ${ }^{18} \mathrm{O}$. After oral ingestion, both isotopes dilute in the body fluids. The hydrogen isotope is eliminated from the body as water, while the oxygen isotope is eliminated as both water and carbon dioxide. The difference between the two elimination rates is therefore a measure of carbon dioxide production (figure $1 \mathrm{~d}$ ). Energy expenditure is calculated from measured $\mathrm{CO}_{2}$ production with Weir's equation:

$$
\mathrm{EE}(\mathrm{kcal})=3.941 \cdot \mathrm{VO}_{2}(\mathrm{l})+1.106 \cdot \mathrm{VCO}_{2}(\mathrm{l})(89)
$$




\section{Figure 1d}

Principle underlying the doubly labeled water method. ${ }^{2} \mathrm{H}$ and ${ }^{18} \mathrm{O}$ are administered to enhance natural enrichments of the isotopes above background levels. The difference between disappearance rates of ${ }^{2} \mathrm{H}$ and ${ }^{18} \mathrm{O}$ approximates the carbon dioxide output, which is then used to calculate energy expenditure (Adapted from Heijman and Roberts (106)).

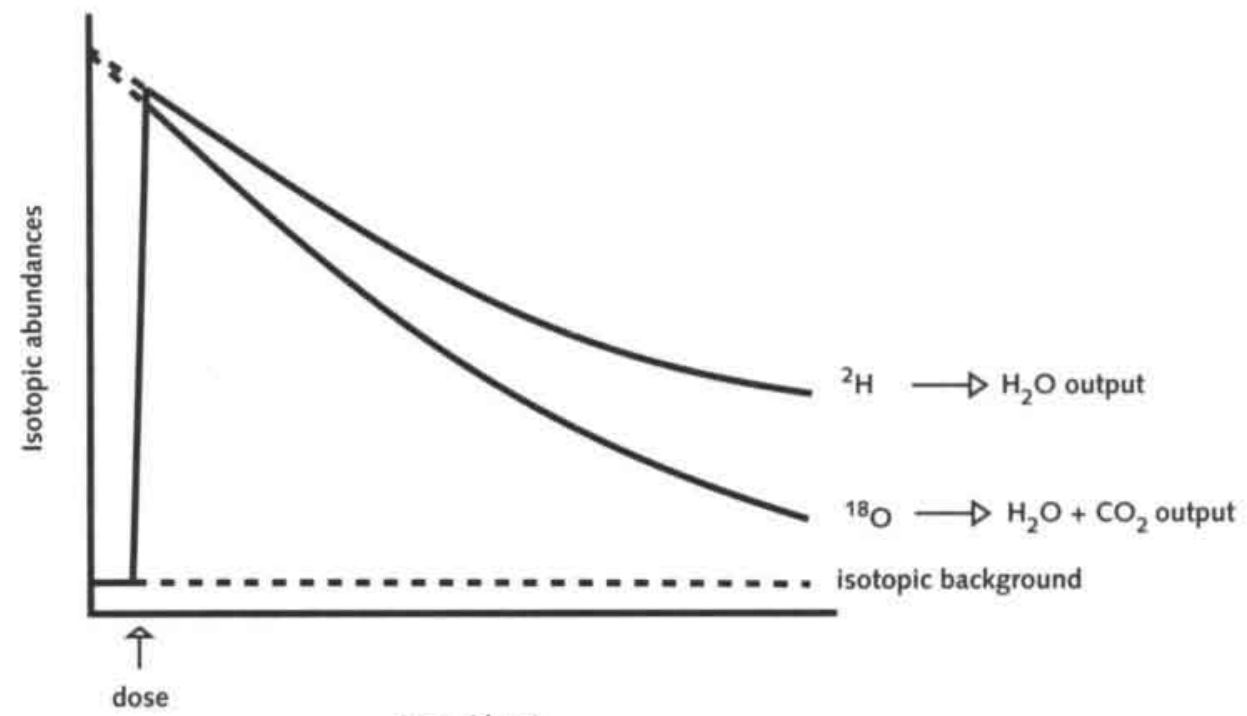

Time (days)

Where oxygen consumption is based on an estimated or measured value of the respiratory quotient $\left(\mathrm{RQ}=\mathrm{VCO}_{2} / \mathrm{VO}_{2}\right)$.

BMR can be measured using an open-circuit, ventilated hood system. It is measured in the morning after an overnight fast, to avoid DIT being included in the measurement. The subjects are asked to lie in supine position for 30 minutes. Oxygen consumption and carbon dioxide production are calculated using the flow through the hood and the oxygen and carbon dioxide concentrations in the incoming and outgoing air. BMR is then calculated using Weir's equation (89), Once TDEE and BMR are known, activity related energy expenditure and physical activity level (PAL) can be calculated.

PAL is a measure introduced by the FAO/WHO/UNU expert committee on energy requirements (90). This committee has expressed energy needs as multiples of the BMR, which is called PAL (91). PAL can be calculated as TDEE/BMR, AEE $=\left(0.9^{*}\right.$ TDEE $)-B M R$, assuming a DIT of $10 \%$.

Using the doubly labeled water method, physical activity can be measured over a period of one to two weeks under free-living conditions, without influencing the natural activity behavior. However, since doubly labeled water is expensive and scarce, this method is not suitable for population-based studies. Neither can it be used to measure physical activity patterns. 
Other methods to measure physical activity related energy expenditure are self-report instruments, personal observation, heart rate monitoring and accelerometers. Personal observation is suitable for small sample sizes when information on a specific type of activity and its duration is required. However, this method is time consuming and expensive, and interferes with children's spontaneous activity patterns (92).

Self-report instruments have proved to correlate only moderately with objective activity measures (93), because children are not able to provide accurate information about their activity patterns. Although heart rate (HR) monitors give more objective information about physical activity, it has been proven in adults $(94-96)$ as well as in children $(97,98)$ that HR monitoring overestimates 24 -hour energy expenditure by about $10 \%$, because factors like emotional stress and posture can contribute to an increase in HR during inactive periods.

A more promising method for the measurement of physical activity related energy expenditure is the use of motion sensors and more specifically, accelerometers. These devices measure the occurrence and intensity of movements. There exist one-axial accelerometers like Caltrac and CSA (Computer Science and Application's activity monitor) and tri-axial accelerometers like Tritrac and Tracmor. Compared to the DLW method, the Caltrac was not found to be accurate by Johnson et al. (99). Ekelund et al. (100) found a good correlation between the CSA accelerometer and DLW data. Unlike Ekelund et al., Johnson converted accelerometer output to kcal/day on the basis of an equation including age, height, weight and gender. Leenders et al. (101) observed significant underestimation of physical activity by the CSA and Tritrac in women. In their study, the output of both meters was converted to energy expenditure parameters using subject characteristics.

The Tracmor has been developed at the department of Human Biology at the University of Maastricht. It has proved to be an objective and reliable tool for assessing activity levels in free-living subjects (102). In contrast to other accelerometers, Tracmor was miniaturized to a small and light device (11 $\mathrm{cm}^{3}$ and $30 \mathrm{~g}$. Tracmor2), which is important for the subject's comfort (103).

The importance of measuring physical activity patterns has become clear when the Tracmor2 was used to assess physical activity patterns in adults (104). It showed that the fraction of time spent on activities of moderate and low intensity is a significant predictor of PAL, indicating that spending less time on low intensity activities positively influences physical activity levels, whereas high intensity activities do not have much influence on the physical activity level. This suggests that an increase in physical activity levels does not necessarily imply high-intensity sports $(104,105)$.

\section{Effects of growth hormone on energy expenditure and physical activity related energy expenditure}

Treating GHD adults with GH has been found to cause an increase in BMR (107-109). Measuring the change in the BMR/fat free mass ratio (FFM) is not the best method to investigate whether this increase can be entirely attributed to an increase in FFM. Ravussin and Bogardus (110) warned against the use of this method, because the $y$-intercept is 
significantly greater than zero in a regression of BMR against FFM. Expressing data as the $B M R / F F M$ ratio will therefore always result in a higher BMR/FFM in those subjects with a lower FFM. As GHD adults generally have a lower FFM than healthy controls, BMR/FFM will be higher even though their BMR may lie within the normal regression line.

After adjusting for FFM as suggested by Ravussin and Bogardus, Snel et al. (109) found a significant increase in BMR. This suggests that other factors besides the change in FFM also influence the increase in BMR. The higher FFM adjusted BMR may be due to changes in fuel metabolism. According to Snel, an increase in gluconeogenesis may be responsible for the higher BMR. Juul and Salomon $(111,112)$ attributed most of the increase in metabolic rate to the fat oxidation resulting from the lipolytic effect of growth hormone.

Also after the introduction of GH therapy in GHD children, changes in energy expenditure occur $(21,113)$. Gregory for example, showed a significant increase in BMR (by $12 \%$ ) after 6 weeks of growth hormone treatment (113). The termination of GH treatment when the final height is reached can also affect energy expenditure (114). Cowan demonstrated that BMR was reduced within two weeks after growth hormone treatment was stopped, and remained suppressed for up to one year later in individuals previously identified as having childhood onset GHD (115).

Little is known about the effect of growth hormone therapy on activity related energy expenditure. Although parents have reported their children to be livelier and more active after the start of therapy, Gregory could not confirm this using the DLW method. Because growth hormone treatment causes an increase in fat free mass, an effect on physical activity related energy expenditure might be expected. In the study by Gregory, however, the increase in TDEE was a reflection of the increase in BMR, suggesting that growth hormone treatment has no evident effect on activity related energy expenditure.

\section{Body composition}

Although weight is commonly used to estimate nutritional status, weight as an isolated measurement provides little information. Since body weight is the sum of five principal compartments: water, fat, protein, minerals and glycogen, changes in body weight may be the result of changes in any of these compartments. Because the various body compartments are difficult to measure separately, Siri divided the body into two compartments: fat mass (FM) and fat free mass (FFM) (116). Most studies of body composition are based on this two-compartment model.

Knowledge of the fat content of the body has physiological and medical importance. The amount of fat may influence morbidity and mortality, it may alter the effectiveness of drugs and anesthetics and it may affect the ability to withstand exposure to cold and starvation (117). Besides fat mass, water content also reflects the nutritional status of the body. Moore suggested that most illnesses result in increased hydration of the body. He postulated that in disease, as pathologic water accumulation develops, the hydration of the fat free mass may rise from $73 \%$ to $84 \%(118,119)$, indicating that the measurement of body fat and body water provides useful information (117). 
The current density standard is based on three studies in which human male cadavers were analyzed to get more information about the density of fat and fat free mass. (120-122). This analysis was used to define the current density standard of $0.9007 \mathrm{~g} / \mathrm{ml}$ for fat and $1.10 \mathrm{~g} / \mathrm{ml}$ for fat free mass at average body temperature $\left(36^{\circ} \mathrm{C}\right)(116,123)$. However, it has long been known that young tissues differ from old ones in chemical composition (122, $124,125)$. The young body has a higher proportion of water and a lower proportion of minerals; young bones contain less calcium, young muscle less potassium. In addition, the ratio of extracellular water (ECW) to intracellular water (ICW) declines during growth (126). Therefore, the current density standards for fat mass and fat free mass are not applicable to children.

\section{Effects of growth hormone on body composition and physical fitness}

The lipolytic effect of $\mathrm{GH}$ was demonstrated in the 1930s, when studies showed that the injection of rats with extracts from the anterior pituitary gland reduced body fat. Subsequent studies using purified $\mathrm{GH}$ preparations demonstrated that this effect was caused by $\mathrm{GH}$ (127). The most important pathway for accumulating triglycerides in human adipose tissue is the lipoprotein lipase (LPL) pathway. LPL hydrolyzes triglycerides that are transported as VLDL-triglycerides and chylomicrones. Several hormones, like insulin and corticosteroids, regulate the activity of LPL (128). Ottosson et al. showed that GH inhibits lipoprotein lipase activity in human adipose tissue (129). In addition to the effect on fat mass, nitrogen retention increases within days of starting $\mathrm{GH}$ treatment. Increased nitrogen retention reflects increased protein synthesis and fat free mass (115).

Because $\mathrm{GH}$ has effects on the body's fat mass and fat free mass, abnormalities in body composition are to be expected in GHD patients. A few studies have presented data of body mass index (BMI) in children with retarded growth. Leger (130) found a BMI of -0.2 $\mathrm{kg} / \mathrm{m}^{2}$ at the start of therapy for GHD children. Children with intrauterine growth retardation were found to have a BMI of $-1.3 \mathrm{~kg} / \mathrm{m}^{2}$. Baars et al. (131) found a BMI-SDS of 0.09 before $\mathrm{GH}$ treatment, which was comparable to that in normal children. During therapy, BMI initially decreased, to reach a nadir of -0.28 SDS at 6 months. Thereafter, BMI progressively increased to -0.09 SDS after 24 months.

The effects of $\mathrm{GH}$ on fat mass and fat free mass have been investigated in adult patients (18, $111)$ as well as in children $(21,113,132-136)$. The initiation of therapy causes a decrease in fat mass and an increase in fat free mass in $\mathrm{GH}$ deficient patients. By contrast, children who terminate their $\mathrm{GH}$ treatment because they have reached their final height have been found to show an increase in fat mass and a decrease in fat free mass $(114,115,137)$.

The treatment of adult patients with $\mathrm{GH}$ initially results in oedema. However, with the recognition that adults with GHD require significantly smaller doses of $\mathrm{GH}$ than children, the frequency and severity of the problems have been greatly reduced (138). Vaisman et al. found no effect on extracellular water (ECW) in children who were treated with $\mathrm{GH}$ (135). Parra (136) showed ECW for age to be lower in GHD children before the start of therapy, although ECW for height was normal. 
The effect of $\mathrm{GH}$ on body composition has been found to be transient, $(113,130,132,133$, $135,139)$. Vaisman (21) observed that fat as a percentage of body weight decreased within 2 months and was unchanged at 4 and 6 months of treatment. Hindmarsh, who examined triceps and subscapular skinfolds, reported a significant decrease after 6 months and a return to baseline at 12 months (140).

Besides the changes in fat mass and fat free mass in GHD patients, changes in fat distribution have been described. The distribution of body fat in GHD adults is characteristically altered; there is an increase in the abdominal and visceral depots, resulting in an increase in the waist-to-hip ratio compared with controls $(141,142)$. Studies $(18,143)$ have shown that the reduction in fat mass during GH therapy is region-specific, with the greatest reduction occurring centrally and smaller changes occurring in the limbs. These findings confirm the observations by Salomon et al. (111), who showed that GH reduces the waist-to-hip ratio. Thus, $\mathrm{GH}$ promotes a redistribution of adipose tissue from abdominal to peripheral depots. Matsuoka postulated that these regional differences might suggest that $\mathrm{GH}$ has site-selective lipolytic activity. The redistribution of body fat may be due to the effect of interactions with other hormones, whose activity may be different at different sites (144).

Apart from effects on body composition, effects on cardiac function have also become clear in GHD adults. (145-147). They were found to have impaired cardiac function $(148,149)$, which improves after the introduction of $\mathrm{GH}$ therapy $(148,150-153)$. In addition to improved cardiac function, increased exercise tolerance (154-158) and muscle strength have been reported, which might improve physical fitness and the ability to perform everyday tasks. (155, 159-161).

\section{OUTLINE OF THE THESIS}

It is beyond doubt that it is difficult to diagnose GHD. The present study was designed because current methods have proved to be inadequate in predicting the effect of therapy. The aim of the study was to evaluate whether changes in physical activity or body composition shortly after the start of therapy could predict the effect of $\mathrm{GH}$ therapy on long-term growth.

Before deviant physical activity patterns could be identified in children who benefit from GH therapy, more knowledge was needed about physical activity in healthy, normally growing children. Therefore, Chapter 2 shows the results of a literature study, analysing existing studies that had measured total daily energy expenditure with doubly labeled water, in order to evaluate the effect of age on activity. Chapter 3 describes a validation study with the Tracmor 2 accelerometer for the measurement of physical activity in children. This instrument was used in the study reported on in Chapter 4 to evaluate the activity pattern of children compared to that of young adults and the elderly.

Because GH affects energy expenditure and body composition, it was expected that children secreting less $\mathrm{GH}$ would be less physical active and show poorer physical fitness. 
The studies reported on in Chapters 5 and 6 compared the effect of $\mathrm{GH}$ therapy on activity patterns and physical fitness in children receiving $\mathrm{GH}$ therapy with those of healthy controls.

It is known that it is difficult to select children who will benefit from GH therapy. Because previous research has found a relation between the change in height resulting from $\mathrm{GH}$ therapy and changes in body composition $(114,139)$, chapter 7 proposes a new method based on metabolic changes caused by $\mathrm{GH}$ therapy, to select children that will respond to the therapy. This chapter describes the use of changes in body composition after the introduction of $\mathrm{GH}$ therapy as a predictor of the long-term growth effect. Body composition was measured before and after only 6 weeks of $\mathrm{GH}$ therapy, because it is important that the decision to continue or stop therapy can be made soon after its start. 


\section{REFERENCES}

1. Raben MS. Treatment of pituitary dwarf with human growth hormone. I Clin Endo \& Metab 1958;18:901-903.

2. Hintz RL. A Prismatic Case, The prismatic case of Creutzfeldt-Jakob disease associated with pituitary growth hormone treatment. I Clin Endocrinol Metab 1995;80:2298-2301.

3. Van't Hof MA, Haschke F, Darvay S. Euro-Growth references on increments in length, weight, and head and arm circumferences during the first 3 years of life. Euro-Growth Study Group. $J$ Pediatr Gastroenterol Nutr 2000;31 Suppl 1:539-47.

4. Gerver WJ, De Bruin R, Kuromaru R, Kohno H, Ueyama N. Hassan HM, Honda S, Hara T. Relationship between height, sitting height and subischial leg length in Dutch children: presentation of normal values. Acta Paediatr 1995;84:532-535.

5. Gerver WJM, de Bruin R. Paediatric Morphometrics, A reference manual. (second extended edition) ed. Maastricht: Universitaire pers Maastricht, 2001.

6. Fredriks AM, van Buuren S, Burgmeijer RJ, Meulmeester JF, Beuker RJ, Brugman E, Roede MJ, Verloove-Vanhorick SP, Wit JM. Continuing positive secular growth change in The Netherlands 1955-1997. Pediatr Res 2000;47:316-323.

7. De Muinck Keizer-Schrama SMPF, Boukes FS, Oostdijk W, Rikken B. Diagnostiek kleine lichaamslengte bij kinderen [Diagnosis of short stature in children]. Alphen aan de Rijn: van Zuiden Commmunications B.V., 1998.

8. $\mathrm{Li} \mathrm{CH}$, Evans HM, Suimpson ME. Isolation and properties of the anterior hypophysial growth hormone. I Biol Chem 1945;159:353-356.

9. Li CH, Evans HM. The isolation of pituitary growth hormone. Science 1944:99:183-184.

10. Li CH, Papkoff H. Preparations and properties of growth hormone from human and monkey pituitary glands, Science 1956;124:1293-1294.

11. Raben MS. Preparation of growth hormone from pituitaries of man and monkey pituitary glands. Science 1957;125:883-884.

12. Rosenfeld RG, Albertsson-Wikland K, Cassorla F, Frasier SD, Hasegawa Y, Hintz RL, Lafranchi S, Lippe B, Loriaux L, Melmed S, Preece MA, Ranke MB, Reiter EO, Rogol AD, Underwood LE, Werther GA. Diagnostic controversy: the diagnosis of childhood growth hormone deficiency revisited. I Clin Endocrinol Metab 1995;80:1532-1540.

13. Frankenne F, Rentier-Delrue F, Scippo ML, Martial J. Hennen G. Expression of the growth hormone variant gene in human placenta. J Clin Endocrinol Metab 1987:64:635-637.

14. Liebhaber SA, Urbanek M, Ray J, Tuan RS, Cooke NE. Characterization and histologic localization of human growth hormone-variant gene expression in the placenta. J Clin Invest 1989:83:1985-1991.

15. Baumann G. Growth hormone heterogeneity: genes, isohormones, variants, and binding proteins. Endocr Rev 1991;12:424-449.

16. Baumann G. Growth hormone heterogeneity in human pituitary and plasma. Horm Res 1999:51 Suppl 1:2-6. 
17. Harant I, Beauville M, Crampes F, Riviere D, Tauber MT, Tauber JP, Garrigues M. Response of fat cells to growth hormone $(\mathrm{GH})$ : effect of long term treatment with recombinant human $\mathrm{GH}$ in GH-deficient adults. J Clin Endocrinol Metab 1994:78:1392-1395.

18. Lonn L, Johansson G, Sjostrom L, Kvist H, Oden A, Bengtsson BA. Body composition and tissue distributions in growth hormone deficient adults before and after growth hormone treatment. Obes Res 1996:4:45-54.

19. Goodman HM, Schwartz Y, Tai LR, Gorin E. Actions of growth hormone on adipose tissue: possible involvement of autocrine or paracrine factors. Acta Paediatr Scand Suppl 1990;367:132-136.

20. Snyder DK, Clemmons DR, Underwood LE. Treatment of obese, diet-restricted subjects with growth hormone for 11 weeks: effects on anabolism, lipolysis, and body composition. I Clin Endocrinol Metab 1988;67:54-61.

21. Vaisman N, Zadik Z, Akivias A, Voet H, Katz I, Yair S, Ashkenazi A. Changes in body composition, resting energy expenditure, and thermic effect of food in short children on growth hormone therapy. Metabolism 1994;43:1543-1548.

22. Butler AA, Le Roith D. Control of growth by the somatropic axis: growth hormone and the insulinlike growth factors have related and independent roles. Annu Rev Physiol 2001;63:141-164.

23. Le Roith D, Bondy C, Yakar S, Liu JL, Butler A. The somatomedin hypothesis: 2001. Endocr Rev 2001:22:53-74.

24. Muggeo $M$, Tiengo A, Fedele $D$, Crepaldi $G$. The influence of plasma triglycerides on human growth hormone response to arginine and insulin: a study in hyperlipemics and normal subjects. Horm Metab Res 1975;7:367-374.

25. Imaki T, Shibasaki T, Shizume K, Masuda A, Hotta M, Kiyosawa Y, Jibiki K, Demura H, Tsushima $T$, Ling $\mathrm{N}$. The effect of free fatty acids on growth hormone $(\mathrm{GH})$-releasing hormone-mediated $\mathrm{GH}$ secretion in man. I Clin Endocrinol Metab 1985;60:290-293.

26. Carro E, Senaris R, Considine RV, Casanueva FF, Dieguez C. Regulation of in vivo growth hormone secretion by leptin. Endocrinology 1997:138:2203-2206.

27. Tannenbaum GS, Gurd W, Lapointe M. Leptin is a potent stimulator of spontaneous pulsatile growth hormone $(\mathrm{GH})$ secretion and the $\mathrm{GH}$ response to $\mathrm{GH}$-releasing hormone. Endocrinology 1998:139:3871-3875.

28. Vuagnat BA, Pierroz DD, Lalaoui M, Englaro P, Pralong FP, Blum WF, Aubert ML. Evidence for a leptin-neuropeptide $Y$ axis for the regulation of growth hormone secretion in the rat. Neuroendocrinology 1998;67:291-300.

29. Chan YY, Steiner RA, Clifton DK. Regulation of hypothalamic neuropeptide-Y neurons by growth hormone in the rat. Endocrinology 1996:137:1319-1325.

30. Kamegai J, Minami S, Sugihara H. Hasegawa O. Higuchi $\mathrm{H}$. Wakabayashi I. Growth hormone receptor gene is expressed in neuropeptide $\mathrm{Y}$ neurons in hypothalamic arcuate nucleus of rats. Endocrinology 1996;137:2109-2112.

31. Pombo M, Pombo CM, Garcia A, Caminos E, Gualillo O, Alvarez CV, Casanueva FF, Dieguez C. Hormonal control of growth hormone secretion. Horm Res 2001;55 Suppl 1:11-16. 
32. Horvath TL, Diano S, Sotonyi P, Heiman M. Tschop M. Minireview: ghrelin and the regulation of energy balance,a hypothalamic perspective. Endocrinology 2001;142:4163-4169.

33. Date Y, Kojima M, Hosoda H, Sawaguchi A, Mondal MS, Suganuma T, Matsukura S, Kangawa K, Nakazato M. Ghrelin, a novel growth hormone-releasing acylated peptide, is synthesized in a distinct endocrine cell type in the gastrointestinal tracts of rats and humans. Endocrinology 2000;141:4255-4261.

34. Dornonville de la Cour C, Bjorkqvist M, Sandvik AK, Bakke I, Zhao CM, Chen D, Hakanson R. A-like cells in the rat stomach contain ghrelin and do not operate under gastrin control. Regul Pept 2001;99:141-150.

35. Kojima M, Hosoda H, Date Y, Nakazato M, Matsuo H, Kangawa K. Ghrelin is a growthhormone-releasing acylated peptide from stomach. Nature 1999;402:656-660.

36. Korbonits $M$, Kojima $M$, Kangawa $K$, Grossman $A B$. Presence of ghrelin in normal and adenomatous human pituitary. Endocrine 2001;14:101-104.

37. Mori K, Yoshimoto A, Takaya K, Hosoda K, Ariyasu H, Yahata K, Mukoyama M, Sugawara A, Hosoda H, Kojima M, Kangawa K, Nakao K. Kidney produces a novel acylated peptide, ghrelin. FEBS Lett 2000;486:213-216.

38. Gualillo O, Caminos J, Blanco M, Garcia-Caballero T, Kojima M, Kangawa K, Dieguez C, Casanueva F. Ghrelin, a novel placental-derived hormone. Endocrinology 2001;142:788-794.

39. Rosenfeld RG, Ceda G, Cutler CW, Dollar LA, Hoffman AR. Insulin and insulin-like growth factor (somatomedin) receptors on cloned rat pituitary tumor cells. Endocrinology 1985;117:20082016.

40. Yamashita S, Weiss $M$, Melmed S. Insulin-like growth factor I regulates growth hormone secretion and messenger ribonucleic acid levels in human pituitary tumor cells. I Clin Endocrinol Metab 1986;63:730-735.

41. Khan AS, Sane DC, Wannenburg T, Sonntag WE. Growth hormone, insulin-like growth factor-1 and the aging cardiovascular system. Cardiovasc Res 2002;54:25-35.

42. Jones Jl, Clemmons DR. Insulin-like growth factors and their binding proteins: biological actions. Endocr Rev 1995;16:3-34.

43. Binoux M, Hossenlopp P, Hardouin S, Seurin D, Lassarre C, Gourmelen M. Somatomedin (insulinlike growth factors)-binding proteins. Molecular forms and regulation. Horm Res 1986:24:141151.

44. Baxter RC, Martin JL, Beniac VA. High molecular weight insulin-like growth factor binding protein complex. Purification and properties of the acid-labile subunit from human serum. J Biol Chem 1989;264:11843-11848.

45. Baumann G, Shaw MA, Amburn K. Regulation of plasma growth hormone-binding proteins in health and disease. Metabolism 1989;38:683-689.

46. Baumann G, Stolar MW, Amburn K, Barsano CP, DeVries BC. A specific growth hormone-binding protein in human plasma: initial characterization. J Clin Endocrinol Metab 1986;62:134-141.

47. Herington AC, Ymer S, Stevenson J. Identification and characterization of specific binding proteins for growth hormone in normal human sera. J Clin Invest 1986;77:1817-1823. 
48. Rosenfeld RG. Circulating growth hormone binding proteins. Horm Res 1994;42:129-132.

49. Trivedi B, Daughaday WH. Release of growth hormone binding protein from IM-9 lymphocytes by endopeptidase is dependent on sulfhydryl group inactivation. Endocrinology 1988;123:2201-2206.

50. Fuh G, Cunningham BC, Fukunaga R, Nagata S, Goeddel DV, Wells JA. Rational design of potent antagonists to the human growth hormone receptor. Science 1992:256:1677-1680.

51. Berelowitz M, Szabo M, Frohman LA, Firestone S, Chu L, Hintz RL. Somatomedin-C mediates growth hormone negative feedback by effects on both the hypothalamus and the pituitary. Science 1981;212:1279-1281.

52. D'Ercole AJ, Applewhite GT. Underwood LE. Evidence that somatomedin is synthesized by multiple tissues in the fetus. Dev Biol 1980;75:315-328.

53. Kajimoto $Y$, Rotwein $P$. Structure and expression of a chicken insulin-like growth factor $I$ precursor. Mol Endocrinol 1989:3:1907-1913.

54. Roberts CT, Jr., Lasky SR, Lowe WL, Jr., Seaman WT, LeRoith D. Molecular cloning of rat insulinlike growth factor I complementary deoxyribonucleic acids: differential messenger ribonucleic acid processing and regulation by growth hormone in extrahepatic tissues. Mol Endocrinol 1987:1:243-248.

55. Green H, Morikawa M, Nixon T. A dual effector theory of growth-hormone action. Differentiation 1985:29:195-198.

56. Isaksson OG, Lindahl A, Nilsson A, Isgaard J. Mechanism of the stimulatory effect of growth hormone on longitudinal bone growth. Endocr Rev 1987:8:426-438.

57. Ohlsson C, Bengtsson BA, Isaksson OG, Andreassen TT, Slootweg MC. Growth hormone and bone. Endocr Rev 1998:19:55-79.

58. Butler AA, Yakar S, LeRoith D. Insulin-like growth factor-1: compartmentalization within the somatotropic axis? News Physiol Sci 2002;17:82-85.

59. Isaksson OG, Jansson JO, Sjogren K, Ohlsson C. Metabolic functions of liver-derived (endocrine) insulin-like growth factor I. Horm Res 2001;55 Suppl 2:18-21.

60. Yakar S, Liu JL, Le Roith D. The growth hormone/insulin-like growth factor-1 system: implications for organ growth and development. Pediatr Nephrol 2000;14:544-549.

61. Health council of the Netherlands, committee of growth hormone. Use of growth hormone. The Hague: Council of the Netherlands, 1995.

62. Saggese G, Ranke MB, Saenger P, Rosenfeld RG, Tanaka T, Chaussain UL, Savage MO. Diagnosis and Treatment of Growth Hormone Deficiency in Children and Adolescents: Towards a Consensus. Horm Res 1998:50:320-340.

63. Carel J-C, Coste J, Gendrel C, Chaussain JL. Pharmacological testing for the diagnosis of growth hormone deficiency, Growth Horm IGF Res 1998;8:1-8.

64. Takahashi Y, Kipnis DM, Daughaday WH. Growth hormone secretion during sleep. J Clin Invest 1968;47:2079-2090. 
65. Carel J-C, Tresca J-P, Letrait M, Chaussain JL, Lebouc Y, Job J-C, Coste J. Growth hormone testing for the diagnosis of growth hormone deficiency in childhood: a population register-based study. J Clin Endocrinol Metab 1997;82:2117-2121.

66. Cacciari E, Tassoni P, Parisi G, Pirazzoli P, Zucchini S, Mandini M, Cicognani A, Balsamo A. Pitfalls in diagnosing impaired growth hormone $(\mathrm{GH})$ secretion: retesting after replacement therapy of 63 patients defined as GH deficient. J Clin Endocrinol Metab 1992;74:1284-1289.

67. Ropelato MG, Martinez A, Heinrich JJ, Bergada C. Reproducibility and comparison of growth hormone secretion tests. J Pediatr Endocrinol Metab 1996;9:41-50.

68. Ghigo E, Bellone J, Aimaretti G, Bellone S, Loche S, Cappa M, Bartolotta E, Dammacco F. Camanni F. Reliability of provocative tests to assess growth hormone secretory status. Study in 472 normally growing children. J Clin Endocrinol \& Metab 1996;81:3323-3327.

69. Van den Broeck J, Hering P, Van de Lely A, Hokken-Koelega A. Interpretative difficulties with growth hormone provocative retesting in childhood-onset growth hormone deficiency. Horm Res 1999;51:1-9.

70. Rosenfeld RG. Is growth hormone deficiency a viable diagnosis? I Clin Endocrinol Metab 1997;82:349-351.

71. Ranke MB, Guilbaud $O$, Lindberg A, Cole T. Prediction of the growth response in children with various growth disorders treated with growth hormone: analyses of data from the Kabi Pharmacia International Growth Study. International Board of the Kabi Pharmacia International Growth Study. Acta Paediatr Suppl 1993;82 Suppl 391:82-88.

72. Blethen SL, Compton P, Lippe B, Rosenfeld RG, August GP, Johanson A. Factors predicting the response to growth hormone $(\mathrm{GH})$ therapy in prepubertal children with $\mathrm{GH}$ deficiency. J Clin Endocrinol Metab 1993;76:574-579.

73. Ranke MB, Lindberg A, Chatelain P. Wilton P, Cutfield W, Albertsson-Wikland K, Price DA. Derivation and validation of a mathematical model for predicting the response to exogeneous recombinant human growth hormone $(\mathrm{GH})$ in prepubertals children with idiopathic $\mathrm{GH}$ deficiency. J Clin Endocrinol Metab 1999;84:1174-1183.

74. Kristrom B, Karlberg J, Albertsson-Wikland K. Prediction of the growth response of short prepubertal children treated with growth hormone. Swedish Paediatric Study Group for GH treatment. Acta Paediatr 1995;84:51-57.

75. Ranke $M B$, Lindberg $A$, Chatelain $P$, Wilton $P$, Cutfield $W$, Albertsson-Wikland K, Price DA. Predicting the response to recombinant human growth hormone in Turner syndrome: KICS models. KIGS International Board. Kabi International Growth Study. Acta Paediatr Suppl 1999;88:122-125.

76. Ranke $M B$, Lindberg $A$, Guilbaud $O$. Prediction of growth in response to treatment with growth hormone, In: Ranke MB, Gunnarsson R, eds. Progress in Growth hormone therapy- 5 years of KIGS. Mannheim: J\&J Verlag, 1994:98-111.

77. Van den Broeck J. Massa GG, Attanasio A. Matranga A, Chaussain JL, Price DA, Aarskog D, Wit JM. Final height after long-term growth hormone treatment in Turner syndrome. European Study Group. I Pediatr 1995:127:729-735. 
78. Haffner D, Wuhl E, Schaefer F, Nissel R, Tonshoff B, Mehis O. Factors predictive of the short- and long-term efficacy of growth hormone treatment in prepubertal children with chronic renal failure. The German Study Group for Growth Hormone Treatment in Chronic Renal Failure. J Am Soc Nephrol 1998;9:1899-1907.

79. Schonau E, Westermann F, Rauch F, Stabrey A, Wassmer G, Keller E, Bramswig J, Blum WF, A new and accurate prediction model for growth response to growth hormone treatment in children with growth hormone deficiency. Eur J Endocrinol 2001:144:13-20.

80. Mortensen HB, Main K, Michaelsen KF, Kastrup KW, Jorgensen JT, Skakkebaek NE. Predicting and monitoring of growth in children with short stature during the first year of growth hormone treatment. Acta Paediatr Scand 1991:80:1150-1157.

81. Spagnoli A, Branca F, Spadoni GL, Cianfarani S, Pasquino AM, Argiro G, Vitale S, Robins SP, Boscherini B. Urinary pyridinium collagen cross-links predict growth performance in children with idiopathic short stature and with growth hormone $(\mathrm{GH})$ deficiency treated with $\mathrm{GH}$. Skeletal metabolism during GH treatment. J Clin Endocrinol Metab 1996;81:3589-3593.

82. Tapanainen P, Risteli L, Knip M, Kaar ML, Risteli J. Serum aminoterminal propeptide of type III procollagen: a potential predictor of the response to growth hormone therapy. I Clin Endocrinol Metab 1988;67:1244-1249.

83. Carey DE, Goldberg B, Ratzan SK, Rubin KR, Rowe DW. Radioimmunoassay for type I procollagen in growth hormone-deficient children before and during treatment with growth hormone. Pediatr Res 1985;19:8-11.

84. Powell KE, Thompson PD, Caspersen CJ, Kendrick JS. Physical activity and the incidence of coronary heart disease. Annu Rev Public Health 1987;8:253-287.

85. Paffenbarger RS, Wing AL, Hyde RT, Jung DL. Physical activity and incidence of hypertension in college allumni. Am J Epidemiol 1983;117:245-257.

86. Frisch R, Wyshak G, Albright T, Albright N, Schiff I. Lower prevalence of diabetes in female former college athletes compared with nonathletes. Diabetes 1986;35:1101-1105.

87. Janz KF, Dawson JD, Mahoney LT. Tracking physical fitness and physical activity from childhood to adolescence: the Muscatine study. Med Sci Sports Exerc 2000;32:1250-1257.

88. Westerterp-Plantenga MS, Fredrix EWHM, Steffens AB. Food intake and energy expenditure. Heerlen: CRC Press, 1994.

89. Weir JB. New methods for calculating metabolic rate with special reference to protein metabolism. J Physiol 1949:109:1-9.

90. World Health Organization. Energy and protein requirements, report of a joint FAO/WHO/UNU expert consultation. Geneva: WHO, 1985.

91. James WPT, Ferro-Luzzi A, Wateriow JC, Definition of chronic energy deficieny in adults, Report of a working party of the international dietary energy consultancy group. Eur I Clin Nutr $1988 ; 42: 969-981$.

92. Molnar D, Livingstone B. Physical activity in relation to overweight and obesity in children and adolescents. Eur I Pediatr 2000:159 Suppl 1:\$45-55.

93. Sallis JF. Self-report measures of children's physical activity. I Sch Health 1991;61:215-219. 
94. Dauncy MJ, James WPT. Assessment of the heart rate method for determining energy expenditure in man, using a whole-body calorimeter. Br J Nutr 1979:42:1-13.

95. Washburn RA, Montoye HJ. Validity of heart rate as a measure of mean daily energy expenditure. Exerc Physiol 1986;2:161-172.

96. Livingstone MB, Coward WA, Prentice AM, Davies PS, Strain JJ, McKenna PG, Mahoney CA, White JA, Stewart CM, Kerr MJ. Daily energy expenditure in free-living children: comparison of heart-rate monitoring with the doubly labeled water $\left({ }^{2} \mathrm{H}_{2}{ }^{18} \mathrm{O}\right)$ method. Am I Clin Nutr 1992; 56:343-352.

97. Van den Berg-Emons RJG, Saris WHM, Westerterp KR, Van Baak MA. Heart rate monitoring to assess energy expenditure in children with reduced physical activity. Med Sci Sports Exerc 1996;28:496-501.

98. Livingstone $\mathrm{B}$, Robson $\mathrm{P}$, Totton $\mathrm{M}$. Energy expenditure by heart rate in children: an evaluation of calibration techniques. Med Sci Sports Exerc 2000;32:1513-1519.

99. Johnson RK, Russ J, Goran MI. Physical activity related energy expenditure in children by doubly labeled water as compared with the Caltrac accelerometer. Int ; Obes 1998;22:1046-1052.

100. Ekelund U, Sjostrom M, Yngve A, Poortvliet E, Nilsson A, Froberg K, Wedderkopp N, Westerterp K. Physical activity assessed by activity monitor and doubly labeled water in children. Med Sci Sports Exerc 2001;33:275-281.

101. Leenders NY, Sherman WM, Nagaraja HN, Kien CL. Evaluation of methods to assess physical activity in free-living conditions. Med Sci Sports Exerc 2001;33:1233-1240.

102. Bouten CV, Verboeket-van de Venne WP, Westerterp KR, Verduin M, Janssen JD. Daily physical activity assessment: comparison between movement registration and doubly labeled water. I Appl Physiol 1996;81:1019-1026.

103. Westerterp KR. Physical activity assessment with accelerometers. Int J Obes 1999;23 Suppl 3:\$45-49.

104. Westerterp K. Pattern and intensity of physical activity. Nature 2001;410:539.

105. Meijer EP, Goris AHC, Wouters L, Westerterp KR. Physical activity as a determinant of the physical activity level in the elderly. Int J Obes 2001;25:935-939.

106. Heijman MB, Roberts SB. Determination of total energy expenditure in infants using doubly labelled water $\left({ }^{2} \mathrm{H}_{2}{ }^{18} \mathrm{O}\right)$. Andover, Hampshire: Intercept, 1990.

107. Chong PK, Jung RT, Scrimgeour CM, Rennie MJ, Paterson CR. Energy expenditure and body composition in growth hormone deficient adults on exogenous growth hormone. Clin Endocrinol (Oxf) 1994;40:103-110.

108. Stenlof K, Sjostrom L, Lonn L, Bosaeus I, Kvist H, Tolli J, Lindstedt G, Bengtsson BA. Effects of recombinant human growth hormone on basal metabolic rate in adults with pituitary deficiency. Metabolism 1995;44:67-74.

109. Snel YE, Doerga ME, Brummer R, Zelissen PM, Zonderland ML, Koppeschaar HP. Resting metabolic rate, body composition and related hormonal parameters in growth hormone-deficient adults before and after growth hormone replacement therapy. Eur I Endocrinol 1995;133:445450. 
110. Ravussin E, Bogardus C, Chong PK, Jung RT, Scrimgeour CM, Rennie MJ, Paterson CR. Relationship of genetics, age, and physical fitness to daily energy expenditure and fuel utilization. Am J Clin Nutr 1989;49:968-975.

111. Salomon F, Cuneo RC, Hesp R, Sonksen PH. The effects of treatment with recombinant human growth hormone on body composition and metabolism in adults with growth hormone deficiency. N Engl J Med 1989;321:1797-1803.

112. Juul A, Hjortskov N, Jepsen LT, Nielsen B. Halkjaer-Kristensen J, Vahl N, Jorgensen JO, Christiansen JS, Skakkebaek NE. Growth hormone deficiency and hyperthermia during exercise: a controlled study of sixteen GH-deficient patients. I Clin Endocrinol Metab 1995;80:33353340 .

113. Gregory JW, Greene SA, Jung RT, Scrimgeour CM, Rennie MJ. Changes in body composition and energy expenditure after six weeks' growth hormone treatment. Arch Dis Child 1991;66:598-602.

114. Gerver WJ, De Bruin R, Delemarre v d Waal HA, Aldewereld B, Theunissen P, Westerterp KR. Effects of discontinuation of growth hormone treatment on body composition and metabolism. Horm Res 2000:53:215-220.

115. Cowan FJ, Evans WD, Gregory JW. Metabolic effects of discontinuing growth hormone treatment. Arch Dis Child 1999;80:517-523.

116. Siri WE. The Gross Composition of the Body. Adv Biol Med Physiol 1956;4:239-280.

117. Durnin JV, Womersley J, Bradbury MG, Brocklebank JT, Smye SW, Davies PS, Chong PK, Jung RT, Scrimgeour CM, Rennie MJ. Paterson CR. Body fat assessed from total body density and its. estimation from skinfold thickness; measurements on 481 men and women aged from 16 to 72 years. Br J Nutr 1974:32:77-97.

118. Moore FD, Boyden CM. Body cell mass and limits of hydration of the fat free body: Their regulation to estimated skeletal weight. Ann N Y Acad Sci 1963:110:62-71.

119. Moore FD, Oleson KH, MCMurray JD, Parker HV, Ball MR, Boyden CM. The body cell mass and its supporting environment. Philadelphia: W.B. Saunders, 1963.

120. Mitchell HH, Hamilton TS, Steggerda FR, Bean HW. The chemical composition of the adult human body and its bearing on the biochemistry of growth. J Biol Chem 1945:158:685-691.

121. Widdowson EM, McCance RA, Spray CM. The chemical composition of the human body. Clinical Science 1951:10:113-125.

122. Forbes RM, Cooper DM, Mitchell HH. The composition of the adult human body as determined by chemical analysis. I Biol Chem 1953;203:359-366.

123. Brozek J, Grande F, Anderson T, Keys A. Densitometric analysis of body composition: revisions of some quantitative assumptions. Ann N Y Acad Sci 1963:110:113-140.

124. Boileau RA, Lohman TG, Slaughter MH, Ball TE, Going SB, Hendrix MK. Hydration of the fatfree body in children during maturation. Hum Biol 1984;56:651-666.

125. Weststrate JA, Deurenberg P, van Tinteren $\mathrm{H}$. Indices of body fat distribution and adiposity in Dutch children from birth to 18 years of age. Int J Obes 1989:13:465-477. 
126. Friis-Hansen B. Body water compartments in children: changes during growth and related changes in body composition. Pediatrics 1961;28:169-181.

127. Eden S, Bengtsson BA, Oscarsson J. Effects of growth hormone on body composition and metabolism. Acta Pediatr Scand Suppl 1990;367:14-19.

128. Richelsen B. Action of growth hormone in adipose tissue. Horm Res 1997;48 Suppl 5:105-110.

129. Ottosson M, Vikman-Adolfsson K, Enerback S, Elander A, Bjorntorp P, Eden S. Growth hormone inhibits lipoprotein lipase activity in human adipose tissue. I Clin Endocrinol Metab 1995:80:936-941.

130. Leger J, Carel C, Legrand I, Paulsen A, Hassan M, Czernichow P. Magnetic resonance imaging evaluation of adipose tissue and muscle tissue mass in children with growth hormone (GH) deficiency, Turner's syndrome, and intrauterine growth retardation during the first year of treatment with GH. I Clin Endocrinol Metab 1994;78:904-909.

131. Baars J, Van den Broeck J, le Cessie S, Massa G, Wit JM. Body mass index in growth hormone deficient children before and during growth hormone treatment. Horm Res 1998;49:39-45.

132. Hassan HM, Kohno H, Kuromaru R, Honda S, Ueda K. Body composition, atherogenic risk factors and apolipoproteins following growth hormone treatment. Acta Paediatr 1996;85:899-901.

133. Boot AM, Engels MA, Boerma GJ, Krenning EP, De Muinck Keizer-Schrama SM. Changes in bone mineral density, body composition, and lipid metabolism during growth hormone (GH) treatment in children with GH deficiency. I Clin Endocrinol Metab 1997:82:2423-2428.

134. Kuromaru R, Kohno H, Ueyama N, Hassan HM, Honda S, Hara T. Long-term effect of growth hormone (GH) treatment on body composition in children with GH deficiency. Endocr J 1999:46 Suppl:S35-38.

135. Vaisman N, Zadik Z, Shamai Y, Franklin L, Dukhan R. Changes in body composition of patients with subnormal spontaneous secretion of growth hormone, during the first year of treatment with growth hormone. Metabolism 1992;41:483-486.

136. Parra A, Argote RM, Garcia G, Cervantes C, Alatorre S, Perez-Pasten E. Body composition in hypopituitary dwarfs before and during human growth hormone therapy. Metabolism $1979 ; 28: 851-857$

137. Stouthart PJ, de Ridder CM, Rekers-Mombarg LT, van der Waal HA. Changes in body composition during 12 months after discontinuation of growth hormone therapy in young adults with growth hormone deficiency from childhood. I Pediatr Endocrinol Metab 1999;12 Suppl 1:335-338.

138. Moller J, Nielsen S, Hansen TK, Kuromaru R, Kohno H, Ueyama N, Hassan HM. Honda S. Hara T. Growth hormone and fluid retention. Horm Res 1999:51 Suppl 3:116-120.

139. Gregory JW, Greene SA, Jung RT, Scrimgeour CM, Rennie M. Metabolic effects of growth hormone treatment: an early predictor of growth response? Arch Dis Child 1993:68:205-209.

140. Hindmarsh PC, Pringle PJ, Di Silvio L, Brook CG. Effects of 3 years of growth hormone therapy in short normal children. Acta Paediatr Scand Suppl 1990;366:6-12. 
141. Larsson B, Svardsudd K, Welin L, Wilhelmsen L, Bjorntorp P, Tibblin G. Abdominal adipose tissue distribution, obesity, and risk of cardiovascular disease and death: 13 year follow up of participants in the study of men born in 1913. Br Med J (Clin Res Ed) 1984;288:1401-1404.

142. Lapidus L, Bengtsson C, Larsson B, Pennert K, Rybo E, Sjostrom L. Distribution of adipose tissue and risk of cardiovascular disease and death: a 12 year follow up of participants in the population study of women in Gothenburg, Sweden. Br Med I (Clin Res Ed) 1984:289:1257-1261.

143. Bengtsson BA, Eden S, Lonn L, Kvist H, Stokland A, Lindstedt G, Bosaeus I, Tolli J, Sjostrom L, Isaksson $\mathrm{OG}$. Treatment of adults with growth hormone $(\mathrm{GH})$ deficiency with recombinant human GH. I Clin Endocrinol Metab 1993;76:309-317.

144. Matsuoka H, Fors H, Bosaeus I, Rosberg S, Albertsson-Wikland K, Bjarnason R. Changes in body composition and leptin levels during growth hormone $(\mathrm{GH})$ treatment in short children with various GH secretory capacities. Eur J Endocrinol 1999;140:35-42.

145. Bates AS, Van't Hoff W, Jones PJ, Clayton RN. The effect of hypopituitarism on life expectancy. J Clin Endocrinol Metab 1996;81:1169-1172.

146. Bulow B, Hagmar L, Mikoczy Z, Nordstrom CH, Erfurth EM. Increased cerebrovascular mortality in patients with hypopituitarism. Clin Endocrinol (Oxf) 1997;46:75-81.

147. Rosen T, Bengtsson BA. Premature mortality due to cardiovascular disease in hypopituitarism. Lancet 1990;336:285-288.

148. Amato G, Carella C, Fazio S, La Montagna G, Cittadini A, Sabatini D, Marciano-Mone C, Sacca L. Bellastella A. Body composition, bone metabolism, and heart structure and function in growth hormone $(\mathrm{GH})$-deficient adults before and after $\mathrm{GH}$ replacement therapy at low doses. $\mathrm{C}$ Clin Endocrinol Metab 1993:77:1671-1676.

149. Longobardi S, Cuocolo A, Merola B, Di Rella F, Colao A, Nicolai E, Cardei S, Salvatore M, Lombardi $G$. Left ventricular function in young adults with childhood and adulthood onset growth hormone deficiency. Clin Endocrinol (Oxf) 1998:48:137-143.

150. Colao A, di Somma C, Cuocolo A, Spinelli L, Tedesco N. Pivonello R, Bonaduce D, Salvatore M, Lombardi G. Improved cardiovascular risk factors and cardiac performance after 12 months of growth hormone $(\mathrm{GH})$ replacement in young adult patients with $\mathrm{GH}$ deficiency. I Clin Endocrinol Metab 2001;86:1874-1881.

151. Colao A, Cuocolo A, Di Somma C, Cerbone G, Della Morte AM, Nicolai E, Lucci R, Salvatore M, Lombardi $\mathrm{G}$. Impaired cardiac performance in elderly patients with growth hormone deficiency. I Clin Endocrinol Metab 1999;84:3950-3955.

152. Thuesen L, Jorgensen JO, Muller JR, Kristensen BO, Skakkebaek NE, Vahl N, Christiansen JS. Short and long-term cardiovascular effects of growth hormone therapy in growth hormone deficient adults. Clin Endocrinol (Oxf) 1994;41:615-620.

153. Valcavi R, Gaddi O, Zini M, lavicoli M, Mellino U, Portioli I. Cardiac performance and mass in adults with hypopituitarism: effects of one year of growth hormone treatment. I Clin Endocrinol Metab 1995;80:659-666.

154. Cittadini A, Cuocolo A, Merola B, Fazio S, Sabatini D, Nicolai E, Colao A, Longobardi S, Lombardi $\mathrm{G}$, Sacca L. Impaired cardiac performance in $\mathrm{GH}$-deficient adults and its improvement after $\mathrm{GH}$ replacement. Am J Physiol 1994:267:E219-225. 
155. Jorgensen JO, Thuesen L, Muller J, Ovesen P, Skakkebaek NE, Christiansen JS. Three years of growth hormone treatment in growth hormone-deficient adults: near normalization of body composition and physical performance. Eur J Endocrinol 1994;130:224-228.

156. Jorgensen JO, Vahl N, Hansen TB, Thuesen L, Hagen C, Christiansen JS. Growth hormone versus placebo treatment for one year in growth hormone deficient adults: increase in exercise capacity and normalization of body composition. Clin Endocrinol (Oxf) 1996;45:681-688.

157. Nass R, Huber RM, Klauss V, Muller OA, Schopohl J, Strasburger CJ. Effect of growth hormone ( $\mathrm{hGH}$ ) replacement therapy on physical work capacity and cardiac and pulmonary function in patients with hGH deficiency acquired in adulthood. I Clin Endocrinol Metab 1995;80:552-557.

158. Whitehead HM, Boreham C, Mcllrath EM, Sheridan B, Kennedy L, Atkinson AB, Hadden DR. Growth hormone treatment of adults with growth hormone deficiency: results of a 13-month placebo controlled cross-over study. Clin Endocrinol (Oxf) 1992;36:45-52.

159. Cuneo RC, Salomon F, Wiles CM, Hesp R, Sonksen PH. Growth hormone treatment in growth hormone-deficient adults. I. Effects on muscle mass and strength. I Appl Physiol 1991;70:688694.

160. Jorgensen JO, Pedersen SA, Thuesen L, Jorgensen J, Moller J, Muller J, Skakkebaek NE, Christiansen JS. Long-term growth hormone treatment in growth hormone deficient adults. Acta Endocrinol (Copenh) 1991:125:449-453.

161. Rutherford OM, Beshyah SA, Schott J, Watkins Y, Johnston DG. Contractile properties of the quadriceps muscle in growth hormone-deficient hypopituitary adults. Clin Sci (Lond) 1995:88:67-71. 
Chapter 2

PHYSICAL ACTIVITY LEVELS IN CHILDREN AND ADOLESCENTS

Marije B. Hoos ${ }^{1}$, Willem-Jan M. Gerver ${ }^{1}$, Arnold D. Kester ${ }^{2}$ and Klaas R. Westerterp ${ }^{3}$

From the department of Pediatrics ${ }^{1}$, department of Methodology and Statistics ${ }^{2}$ Department of Human Biology ${ }^{3}$ University Maastricht, the Netherlands

International Journal of Obesity 2003;27:605-609. 


\section{ABSTRACT}

\section{Background}

Reference data for physical activity level (PAL) and activity related energy expenditure (AEE) are needed for a better understanding of the effect of activity on childhood health. growth and development

\section{Objective}

Data from 17 studies measuring total daily energy expenditure (TDEE) with doubly labeled water, were combined to construct a reference line for PAL and AEE as a function of age.

\section{Design}

A total of 17 studies from the literature were analyzed; 17 on girls and 16 on boys. Children were aged 3-16 years and of Caucasian origin. Weighted least squares regression was used to obtain reference lines for PAL and AEE as a function of age and gender. The relative numbers of children per study were used as a weighting factor. Basal metabolic rate (BMR) or non-fasted resting metabolic rate and sex were included in the analysis.

\section{Results}

Although there was no difference in PAL between boys and girls, a significant difference in AEE was found between the two sexes.

PAL

$$
0.025 \cdot \text { age }+1.40
$$

$\operatorname{AEE}(M J / d)$

$$
\text { boys: } 0.30 \cdot \text { age }+0.025 \text {; }
$$$$
\text { girls: } 0.21 \cdot \text { age }+0.33
$$

If $B M R$ is measured under non-fasted conditions, the obtained value has to be reduced by 0.21 for PAL and $0.75 \mathrm{MJ} / \mathrm{d}$ for AEE. No relation was found between AEE/ $\mathrm{kg}$ and age.

\section{Conclusions}

PAL and AEE were found to increase with age, showing the importance of age-dependent recommendations. Recommendations for AEE need to be differentiated for sex. To compare PAL and AEE between studies, the measurement conditions of BMR have to be taken into account. The increase in PAL and AEE values can be attributed to an increase in weight, because there was no relation between $A E E / \mathrm{kg}$ and age. 


\section{INTRODUCTION}

Industrialized countries are seeing an increase in the prevalence of childhood obesity, which is strongly associated with obesity in adulthood $(1,2)$. This increase in obesity is probably caused by recent changes in life-style. Not only have there been quantitative and qualitative dietary changes, but children now spend a large part of their free leisure time watching television or playing computer games (3). While in adults the health benefits of physical activity have been well established (4), it is more difficult to determine the beneficial effect of activity on health in children, since it takes many years before any effect can be observed.

As physical activity determines a large proportion of a person's energy requirements, new recommendations for dietary intake and physical activity might be necessary to prevent obesity. A better understanding of the effect of physical activity on childhood obesity could be obtained from information on the average activity level of the current childhood population.

The amount of physical activity can be expressed as the physical activity level (PAL) or as the activity-related energy expenditure (AEE). The basis for PAL was formulated in 1985 by the FAO/WHO/UNU expert committee on energy requirements (5). This committee expressed the energy needs as multiples of the BMR (basal metabolic rate). The index TDEE (total daily energy expenditure) over BMR (TDEE/BMR) was referred to as the PAL (6). TDEE and BMR can subsequently be used to calculate the activity-related energy expenditure: $A E E=(0.9 *$ TDEE $)-B M R$, assuming a diet induced thermogenesis (DIT) of $10 \%$.

In 1995, energy requirements were reconsidered by the International Dietary Exchange Consultancy group (IDECG) (7). Instead of using energy intake data of healthy thriving children, which used to be the basic assumption in the previous reference data, this group used energy expenditure data based on the doubly labeled water (DLW) method, heart rate monitoring and activity diaries. The panel also recommended energy requirements based on PAL.

Normal levels for PAL are the subject of ongoing debate in adults and also in children. The recommendations, which use PAL values to calculate total daily energy expenditure show little differentiation for ages, which makes it impossible to calculate the expected PAL or AEE value at a certain age.

The DLW method is currently regarded as the gold standard for measuring energy expenditure (8), as it is reasonably easy to use and a valuable method, based on stable isotopes. Since, the isotopes are expensive, most studies have included small numbers of subjects. The present paper analyzes combined data from 17 studies from literature with the aim of constructing a reference line for PAL and AEE as a function of age. Separate lines were constructed for boys and girls to investigate the effect of sex. 


\section{METHODS}

All studies from the literature that included TDEE measurement by DLW among children aged 3-16 were potentially eligible for inclusion in the present review. The studies were found by a computerized search for relevant articles on MEDLINE (Pubmed) using the following terms: double labeled water, DLW and TDEE with the limit: all children: 0-18 years. In addition the references of the found articles were screened.

The ethnicity of the subjects was predominantly Caucasian. Only in two studies $(9,10)$, containing 82 and $78 \%$ of Caucasian children, the distinction between ethnic groups could not be made.

All studies distinguished between data for boys and girls. Intervention studies were excluded, or only their basal values were used. Studies on obese and undernourished children were excluded. Table $2 \mathrm{a}$ and $2 \mathrm{~b}$ describe the mean percentage (and range) of fat mass or the body mass index (BMI) (if no data on fat mass were available) of the study populations. Studies with subject groups outside these ranges were not evaluated.

Studies indicating that resting metabolic rate was measured after the consumption of breakfast were marked as non-fasted (NF) in table $2 \mathrm{a}$ (for boys) and table $2 \mathrm{~b}$ (for girls). Other studies, including studies with predicted metabolic rate, were marked as fasted (F). The regularly applied protocol, where the thermic effect of food was included, was the consumption of a usual breakfast at home before the children came to the laboratory $(9,11)$.

Two studies $(12,13)$ calculated BMR values, using Schofield's formula (14), while the other studies measured BMR values using a ventilated hood system. The measuring period of the DLW method was within the optimal range of 7-14 days (15). PAL was calculated as TDEE/BMR, while AEE was calculated as (0.9 - TDEE)-BMR, assuming a DIT of $10 \%$.

\section{STATISTICS}

To compensate for the differences in the number of children per study, a weighted least squares linear regression was performed between age and PAL, age and AEE, and between age and $A E E / \mathrm{kg}$ for both sexes, using the relative number of children per study as the weighting factor. To test the difference between boys and girls, an interaction term (age*sex) was included in the analysis. Since some studies measured non fasted metabolic rate instead of $B M R$, a parameter named feeding $(B M R=0$, non fasted metabolic rate $=1)$ was included in the analysis.

\section{RESULTS}

The energy expenditure parameters used in each study are listed in table $2 \mathrm{a}$ for boys and in table $2 \mathrm{~b}$ for girls. In all, 16 studies were included for boys and 17 for girls. 
Table 2a Energy expenditure parameters per study for boys.

\begin{tabular}{|c|c|c|c|c|c|c|c|c|}
\hline Author & $\mathrm{n}$ & $\begin{array}{l}\text { Age } \\
\text { (years) }\end{array}$ & $\begin{array}{l}\text { BMR } \\
(M / d)\end{array}$ & $\begin{array}{l}\text { TDEE } \\
(\mathrm{MJ} / \mathrm{d})\end{array}$ & $\begin{array}{l}\text { AEE } \\
(\mathrm{MJ} / \mathrm{d})\end{array}$ & PAL & $\begin{array}{l}\text { BMR } \\
F / N F\end{array}$ & $\begin{array}{l}\% \text { fat mass } \\
\text { ( } \pm \text { sd) }\end{array}$ \\
\hline Atkin et $\mathrm{al}^{(12)}$ & 39 & 3.1 & 3.45 & 5.12 & 1.15 & 1.48 & $\mathrm{~F}$ & $23(6)$ \\
\hline Bandini et $\mathrm{al}^{(34)}$ & 13 & 14.4 & 7.26 & 13.00 & 4.44 & 1.79 & $\mathrm{~F}$ & $16(5)$ \\
\hline Bandini et al(35) & 2 & 16.2 & 7.42 & 12.84 & 4.14 & 1.73 & $\mathrm{~F}$ & $17(3)$ \\
\hline \multirow[t]{3}{*}{ Black et $\left.\mathrm{al}\right|^{(36)}$} & 29 & 4.7 & 3.80 & 6.10 & 1.69 & 1.61 & $\mathrm{~F}$ & $16(2)^{a}$ \\
\hline & 32 & 9.8 & 3.12 & 9.80 & 3.12 & 1.72 & $F$ & $20(4)^{a}$ \\
\hline & 31 & 14.5 & 8.10 & 14.10 & 4.59 & 1.74 & $\mathrm{~F}$ & $25(9)^{a}$ \\
\hline Bratteby et al(37) & 25 & 15.0 & 7.31 & 13.82 & 5.13 & 1.89 & $\mathrm{~F}$ & $16(6)$ \\
\hline Ekelund et al ${ }^{(13)}$ & 15 & 9.1 & 5.21 & 8.87 & 2.78 & 1.70 & $\mathrm{~F}$ & $20(6)$ \\
\hline Fontvieille et $\mathrm{al}^{(3)}$ & 15 & 5.4 & 4.34 & 5.92 & 0.98 & 1.36 & $\mathrm{~F}$ & $22(4)$ \\
\hline \multirow[t]{3}{*}{ Goran et $\mathrm{al}^{(38)}$} & 5 & 4.0 & 4.48 & 5.64 & 0.59 & 1.26 & NF & $17(5)$ \\
\hline & 8 & 5.0 & 4.78 & 6.26 & 0.85 & 1.31 & NF & $19(4)$ \\
\hline & 3 & 6.0 & 5.06 & 6.02 & 0.35 & 1.19 & NF & $20(2)$ \\
\hline Goran $^{(11)}$ & 25 & 5.3 & 4.57 & 5.78 & 0.63 & 1.27 & NF & $19(4)$ \\
\hline \multirow[t]{3}{*}{ Goran et $\mathrm{al}^{(39)}$} & 11 & 5.3 & 4.91 & 6.59 & 1.02 & 1.34 & NF & $13(4)$ \\
\hline & 11 & 6.4 & 5.29 & 7.54 & 1.50 & 1.42 & NF & $16(5)$ \\
\hline & 11 & 9.3 & 5.91 & 8.67 & 1.89 & 1.47 & NF & $22(7)$ \\
\hline Hoffman et $\mathrm{al}^{(40)}$ & 14 & 10.2 & 5.21 & 9.03 & 2.92 & 1.73 & $F$ & $17(6)$ \\
\hline Johnson et $\mathrm{al}^{(41)}$ & 17 & 8.2 & 5.54 & 8.04 & 1.70 & 1.45 & NF & $25(7)$ \\
\hline \multirow[t]{4}{*}{ Livingstone et $\mathrm{al}^{(42)}$} & 6 & 7.5 & 4.72 & 7.98 & 2.46 & 1.69 & $\mathrm{~F}$ & $18(4)$ \\
\hline & 5 & 9.3 & 4.75 & 9.77 & 4.04 & 2.05 & $\mathrm{~F}$ & $19(4)$ \\
\hline & 5 & 12.3 & 6.30 & 10.69 & 3.32 & 1.70 & $\mathrm{~F}$ & $24(5)$ \\
\hline & 3 & 15.4 & 6.70 & 11.00 & 3.18 & 1.64 & $\mathrm{~F}$ & $14(5)$ \\
\hline Luke et $\mathrm{al}^{(43)}$ & 5 & 8.4 & 5.40 & 8.83 & 2.55 & 1.64 & $F$ & $25(12)$ \\
\hline Nguyen et $\mathrm{al}^{(9)}$ & 36 & 5.2 & 4.50 & 6.40 & 1.26 & 1.42 & NF & $14^{b}$ \\
\hline Sun et $\mathrm{al}^{(44)}$ & 21 & 8.3 & 5.20 & 7.12 & 1.21 & 1.37 & $\mathrm{~F}$ & $24^{b}$ \\
\hline
\end{tabular}

$B M R$, basal metabolic rate; TDEE, total daily energy expenditure; AEE, activity related energy expenditure; $P A L$, physical activity level. $F=B M R, N F=$ Non fasting metabolic rate. ${ }^{a} \mathrm{BMI}$ are given because no data on fat mass were available. bNo standard deviation (sd) was available because $\%$ fat mass was calculated from weight and fat mass. 
The weighted least squares linear regression yielded the following regression equation for PAL:

$$
\begin{aligned}
& \mathrm{PAL}=0.025^{\circ} \text { age }+1.40 \\
& (r=0.85, p<0.001, \text { standard error }=0.10)
\end{aligned}
$$

If the non-fasted metabolic rate is measured, the obtained value should be reduced by 0.21 , because feeding was a significant $(p<0.0001)$ variable in the regression model. The inclusion of age and age ${ }^{*}$ sex in the analysis was not significant ( $F$ change $=1.62, p=0.21$ ).

For AEE, there was a significant difference between boys and girls ( $F$ change 12.5, $\mathrm{p}<$ $0.0001)$. Therefore equations are given for boys and girls separately:

$$
\text { Boys: } \mathrm{AEE}=0.30^{*} \text { age }+0.025 ; \quad \text { Girls: } \mathrm{AEE}=0.21 \cdot \text { age }+0.33
$$$$
(r=0.94, p<0.001 \text {, standard error }=0.44)
$$

Also in this model feeding was a significant contributor. So if the non-fasted metabolic rate is measured, AEE has to be reduced with $0.75(\mathrm{MJ} / \mathrm{d})$. AEE/ $\mathrm{kg}$ was not significantly related to age for boys nor for girls.

\section{DISCUSSION}

For all kinds of research questions, energy expenditure of children is measured. Several studies use the DLW method, which is regarded as the 'gold standard'. The results of these studies are used in the present paper to estimate the relation between physical activity and age represented by the construction of a reference line.

Reference data for PAL and AEE are needed for a better understanding of the activity level of children, which is especially relevant in childhood obesity. Several studies have demonstrated a negative relation between body fat and physical activity (16-19) or activity time (20). Some studies showed a sex difference in the relation of physical activity and body fat (21-23). All these studies show the importance of physical activity in the treatment of obesity, which can be evaluated if normal values of a healthy population are available.

Although children may appear to be more active than adults, the present review actually found low values in young children increasing to adult values with age. This might be explained from the observation made by Noland et al. (24) who showed that the energy cost of playing is less than that of a slow walk. Besides, children's activities are not only low in intensity but also not sustained over extended periods of time (25). Although children need more energy per kilogram body weight to perform a particular activity than adults (26), their lower body weight leads to a smaller overall energy expenditure compared to older subjects.

In addition to the effect of body weight, there is a pronounced difference between children and adults in the time they are active. Adults showed to have a mean sleeping time of 8 hours $(27,28)$. In a recent study we found a mean sleeping time of 11 hours in children 
Table 2b Energy expenditure parameters per study for girls.

\begin{tabular}{|c|c|c|c|c|c|c|c|c|}
\hline Author & $n$ & $\begin{array}{l}\text { Age } \\
\text { (years) }\end{array}$ & $\begin{array}{l}\text { BMR } \\
(M J / d)\end{array}$ & $\begin{array}{l}\text { TDEE } \\
(\mathrm{MJ} / \mathrm{d})\end{array}$ & $\begin{array}{l}\text { AEE } \\
(M J / d)\end{array}$ & PAL & $\begin{array}{l}\text { BMR } \\
\text { F/NF }\end{array}$ & $\begin{array}{l}\% \text { fat mass } \\
( \pm s d)\end{array}$ \\
\hline Atkin et $\mathrm{al}^{(12)}$ & 38 & 3.1 & 3.19 & 4.85 & 1.17 & 1.52 & $\mathrm{~F}$ & $25(6)$ \\
\hline Bandini et al ${ }^{(34)}$ & 10 & 14.1 & 5.98 & 10.12 & 3.13 & 1.69 & $\mathrm{~F}$ & $25(7)$ \\
\hline Bandini et $\mathrm{al}^{(35)}$ & 2 & 14.4 & 6.51 & 12.28 & 4.55 & 1.89 & $\mathrm{~F}$ & $33(2)$ \\
\hline \multirow[t]{3}{*}{ Black et $\mathrm{al}^{(36)}$} & 21 & 4.9 & 3.60 & 5.50 & 1.35 & 1.53 & $\mathrm{~F}$ & $15(1)^{a}$ \\
\hline & 24 & 9.2 & 4.80 & 8.00 & 2.40 & 1.67 & $\mathrm{~F}$ & $18(2)^{a}$ \\
\hline & 26 & 14.8 & 6.70 & 11.40 & 3.56 & 1.70 & $\mathrm{~F}$ & $27(9)^{a}$ \\
\hline Bratteby et $\mathrm{al}^{(37)}$ & 25 & 15.0 & 5.97 & 10.70 & 3.66 & 1.79 & $\mathrm{~F}$ & $28(6)$ \\
\hline Craig et al (10) & 49 & 10.1 & 5.35 & 8.37 & 2.18 & 1.56 & $\mathrm{~F}$ & $21(6)$ \\
\hline Ekelund et $\mathrm{al}^{(13)}$ & 11 & 9.1 & 5.14 & 8.25 & 2.29 & 1.61 & $\mathrm{~F}$ & $27(6)$ \\
\hline Fontvieille et $\mathrm{al}\left({ }^{(3)}\right.$ & 13 & 5.5 & 4.01 & 5.63 & 1.06 & 1.41 & $\mathrm{~F}$ & $23(5)$ \\
\hline \multirow[t]{3}{*}{ Goran et $\mathrm{al}\left(\mathrm{f}^{(38)}\right.$} & 4 & 4.0 & 4.14 & 4.39 & -0.19 & 1.06 & NF & $19(4)$ \\
\hline & 4 & 5.0 & 4.63 & 5.69 & 0.49 & 1.23 & NF & $26(4)$ \\
\hline & 6 & 6.0 & 4.75 & 6.05 & 0.69 & 1.27 & NF & $26(7)$ \\
\hline Goran $^{(11)}$ & 26 & 5.1 & 4.24 & 5.24 & 0.48 & 1.24 & NF & $26(7)$ \\
\hline \multirow[t]{3}{*}{ Goran et al(39) } & 11 & 5.5 & 4.57 & 5.71 & 0.57 & 1.25 & NF & $19(5)$ \\
\hline & 11 & 6.6 & 4.79 & 7.59 & 2.05 & 1.59 & NF & $20(6)$ \\
\hline & 11 & 9.5 & 5.44 & 6.72 & 0.61 & 1.24 & NF & $27(6)$ \\
\hline Hoffman et $\mathrm{al}^{(40)}$ & 15 & 10.0 & 4.66 & 8.08 & 2.61 & 1.73 & $\mathrm{~F}$ & $24(6)$ \\
\hline Johnson et $\mathrm{al}^{(41)}$ & 14 & 8.5 & 5.19 & 6.50 & 0.65 & 1.25 & NF & $26(7)$ \\
\hline \multirow[t]{4}{*}{ Livingstone et $\mathrm{al}^{(42)}$} & 5 & 7.4 & 4.36 & 7.14 & 2.07 & 1.64 & $\mathrm{~F}$ & $21(2)$ \\
\hline & 4 & 9.2 & 4.43 & 8.14 & 2.89 & 1.84 & $F$ & $27(3)$ \\
\hline & 5 & 12.4 & 5.85 & 9.89 & 3.05 & 1.69 & $\mathrm{~F}$ & $28(3)$ \\
\hline & 3 & 15.6 & 5.14 & 9.57 & 3.48 & 1.86 & $\mathrm{~F}$ & $27(9)$ \\
\hline Luke et al ${ }^{(43)}$ & 4 & 6.8 & 4.47 & 6.74 & 1.59 & 1.51 & $\mathrm{~F}$ & $35(9)$ \\
\hline Nguyen et al(9) & 35 & 5.5 & 4.30 & 5.90 & 1.01 & 1.37 & NF & $18^{b}$ \\
\hline Sun et $\mathrm{al}^{(44)}$ & 18 & 8.4 & 5.35 & 8.14 & 1.97 & 1.52 & $F$ & $39^{b}$ \\
\hline
\end{tabular}

$B M R$, basal metabolic rate; TDEE, total daily energy expenditure; AEE, activity related energy expenditure; $P A L$, physical activity level. $F=B M R, N F=$ Non fasting metabolic rate. ${ }^{a} \mathrm{BMI}$ are given because no data on fat mass were available. ${ }^{b}$ No standard deviation (sd) was available because \% fat mass was calculated from weight and fat mass. 
with a mean age of 8.6 years (personal observation). As children grow older, they sleep less and spend more time on physical activities, resulting in higher PAL and AEE values.

The present review found no difference in PAL values between boys and girls, but did show a difference between the sexes in AEE. Boys had higher AEE values than girls, which might be explained by the difference in body composition between the two. Body composition does not influence PAL, because this parameter adjusts energy expenditure for BMR, which depends heavily on body composition.

PAL and AEE describe the amount of energy spent on activity. However energy costs of physical activity do not need to be identical to body movement (29). Schoeller and Jefford (30) suggested normalizing the energy expenditure of physical activity by division by body weight. No relation was found between $\mathrm{AEE} / \mathrm{kg}$ and age, which means that the increase in $\mathrm{PAL}$ and $\mathrm{AEE}$ can be contributed to the increase in weight.

Longitudinal studies describing the participation into different activity levels (31-33), measured by interviews and questionnaires, reported a decline in physical activity with age especially after the age of 12-15 years. The time spent on activities decreases, but because there is an increase in weight the total amount of energy spent on physical activity might increase.

PAL was defined by the WHO in 1985 as TDEE/BMR. However sometimes non fasted metabolic rate, which includes the thermic effect of food, was measured. In the present analysis we corrected for this and showed that for the comparison of PAL and AEE data, one has to take the measurement conditions of BMR in mind.

Because of the high cost of the DLW method, the studies tended to include relatively small numbers of children. Our analysis would have yielded more precise results if ages and energy expenditure data had been available for individual subjects. The ratio of the means may differ from the mean of the individual ratios. As it was, we had to use aggregated data, which could have attenuated the relation. Moreover, we cannot exclude the possibility that another factor, related to age and influencing TDEE, could be (at least partly) responsible for the observed relations.

In conclusion, PAL and AEE values increased with age. The increase can be attributed to an increase in body weight. 


\section{REFERENCES}

1. Mossberg HO. Forty year follow-up of overweight children. Lancet 1989;2:491-494.

2. Gortmaker SL, Dietz WH, Sobol AM, Wehler CA. Increasing paediatric obesity in the United States. Am J Dis Child 1987:141:491-494.

3. Fontvieille AM, Herper IT, Spraul M, Ravussin E. Daily energy expenditure by five-year-old children, measured by doubly labeled water. I Pediatr 1993:123:200-207.

4. U.S. department of health and human services. Physical activity and health: a report of the surgeon general. Atlanta, GA: U.S.: Department of health and human services, centers for disease control and prevention, national center for chronic disease prevention and health promotion, 1996.

5. World Health Organization. Energy and protein requirements, report of a joint FAO/WHO/UNU expert consultation. Geneva: WHO, 1985.

6. James WPT, Ferro-Luzzi A, Waterlow JC. Definition of chronic energy deficieny in adults. Report of a working party of the international dietary energy consultancy group. Eur I Clin Nutr 1988;42:969-981.

7. Torun B, Davies PSW, Livingstone MBE, Paolissis M, Spurr GB. Energy requirements and dietary recommendations for children and adolescents 1 to 18 years old. Eur I Clin Nutr 1996:50:S3781.

8. Westerterp KR, Bouten CVC. Physical activity assessment: Comparison between movement registration and doubly labeled water method, Z Ernahrungswiss 1997;36:263-267.

9. Nguyen VT, Larson DE, Johnson RK, Goran MI. Fat intake and obesity in children of lean and obese parents. Am J Clin Nutr 1996;63:507-513.

10. Craig SB, Bandini LG, Lichtenstein AH, Schaefer EJ, Dietz WH. The impact of physical activity on lipids, lipoproteins, and blood pressure in preadolescent girls. Pediatrics 1996;98:389-395.

11. Goran MI, Kaskoun M, Johnson R, Martinez C, Kelly B, Hood V. Energy expenditure and body fat distribution in Mohawk children. Pediatrics 1995;95:89-95.

12. Atkin L-M, Davies PSW. Diet composition and body composition in preschool children. Am I Clin Nutr 2000;72:15-21.

13. Ekelund U, Sjostrom M, Yngve A, Poortvliet E, Nilsson A, Froberg K, Wedderkopp N, Westerterp K. Physical activity assessed by activity monitor and doubly labeled water in children. Med Sci Sports Exerc 2001;33:275-281.

14. Schofield WN. Predicting basal metabolic rate, new standards and review of previous work. Hum Nutr Clin Nutr 1985;39:5-41.

15. Westerterp KR, Wouters L, Van Marken-Lichtenbelt W. The Maastricht protocol for the measurement of body composition and energy expenditure with labeled water. Obes Res 1995:3:49-57.

16. Bar-Or O. Physical activity and physical training in childhood obesity. I Sports Med Phys Fit 1993;33:323-329. 
17. Obarzanek E, Schreiber GB, Crawford PB, Goldman SR, Barrier PM, Frederick MM, Lakatos E. Energy intake and physical activity in relation to indexes of body fat: the National Heart, Lung and Blood Institute Growth and Health Study. Am J Clin Nutr 1994;60:15-22.

18. Wilkinson PW, Parkin JM, Pearison G, Strong $H$, Sykes P. Energy intake and physical activity in obese children. Brit Med J 1977:6063:756.

19. Dietz WH, Gortmaker SL. Do we fatten our children at the television set? Obesity and television viewing in children and adolescents. Pediatrics 1985;75:807-812.

20. Goran MI, Hunter $\mathrm{G}$, Johnson R. Physical actvity related energy expenditure and fat mass in young children. Intern I Obes 1997;21:171-178.

21. Ball EJ, O'Connor J, Abbott R, Steinbeck KS, Davies PSW, Wishart C, Gaskinand KJ, Baur LA. Total energy expenditure, body fatness, and physical activity in children aged 6-9 years. Am J Clin Nutr 2001:74:524-528.

22. Ku LC, Shapiro LR, Crawford PB, Huenemann RL. Body composition and physical activity in 8year-old children. Am J Clin Nutr 1981;34:2770-2775.

23. Schoeller DA. Measurement of energy expenditure in free-living humans by using doubly labeled water. I Nutr 1988;118:1278-1289.

24. Noland M, Danner F, Dewalt K, McFadden M, Kotchen JM. The measurement of physical activity in young children. Res Q Exerc Sport 1990:61:146-153.

25. Bailey RC, Olson J, Pepper SL, Porszasz J, Barstow TJ, Cooper DM. The level and tempo of children's physical activities: an observational study. Med Sci Sports Exerc 1995;27:1033-1041.

26. Waters RLL, B.R. Perry, J. Byrd, R. Energy-Speed relationship of walking: standard tables. Orthop Res Soc 1988:6:215-222.

27. Bouten CV, Verboeket-van de Venne WP, Westerterp KR, Verduin M, Janssen JD. Daily physical activity assessment: comparison between movement registration and doubly labeled water. J Appl Physiol 1996:81:1019-1026.

28. Meijer EP, Goris AHC, Wouters L, Westerterp KR. Physical activity as a determinant of the physical activity level in the elderly. Int $;$ Obes 2001;25:935-939.

29. Ekelund U. Aman J, Yngve A, Renman C, Westerterp K, Sjostrom M. Physical activity but not energy expenditure is reduced in obese adolescents: a case-control study. Am J Clin Nutr 2002:76:935-941.

30. Schoeller DA, Jefford G. Determinants of the energy costs of light activities: inferences for interpreting doubly labeled water data. Int I Obes Relat Metab Disord 2002;26:97-101.

31. Caspersen CI, Pereira MA, Curran KM. Changes in physical activity patterns in the United States, by sex and cross-sectional age. Med Sci Sports Exerc 2000;32:1601-1609.

32. van Mechelen W, Twisk JW, Post GB, Snel J, Kemper HC. Physical activity of young people: the Amsterdam Longitudinal Growth and Health Study. Med Sci Sports Exerc 2000:32:1610-1616.

33. Telama $R$, Yang $X$. Decline of physical activity from youth to young adulthood in Finland. Med Sci Sports Exerc 2000;32:1617-1622. 
34. Bandini LG, Schoeller DA, Dietz WH. Energy expenditure in obese and nonobese adolescents. Paediatr Res 1990;27:198-203.

35. Bandini LG, Schoeller DA, Edwards J, Young VR, Oh SH, Dietz WH. Energy expenditue during carbohydrate overfeeding in obese and nonobese adolescents. Am J Physiol 1989;256:E357. 367.

36. Black AE, Coward WA, Cole TJ, Prentice AM. Human energy expenditure in affluent societies: an analysis of 574 doubly-labelled water measurements. Eur J Clin Nutr 1996;50:72-92.

37. Bratteby L-E, Sandhagen B, Fan H, Enghardt H, Samuelson C. Total energy expenditure and physical activity as assessed by the doubly labeled water method in Swedish adolescents in whom energy intake was underestimated by 7-d diet records. Am J Clin Nutr 1998;67:905-911.

38. Goran MI, Carpenter WH, Poehlman ET. Total energy expenditure in 4- to 6-yr-old children. Am J Physiol 1993;264:E706-711.

39. Goran MI, Gower BA, Nagy TR, Johnson RK. Developmental changes in energy expenditure and physical activity in children: evidence for a decline in physical activity in girls before puberty. Pediatrics 1998;101:887-891.

40. Hoffman DJ, Sawaya AL, Coward WA, Wright A, Martins PA, Nascimento C, Tucker KL, Roberts SB. Energy expenditure of stunted and nonstunted boys and girls living in the shantytowns of Sao Paulo, Brazil. Am J Clin Nutr 2000;72:1025-1031.

41. Johnson RK, Russ J, Goran MI. Physical activity related energy expenditure in children by doubly labeled water as compared with the Caltrac accelerometer. Int $j$ Obes 1998;22:1046-1052.

42. Livingstone MB, Coward WA, Prentice AM, Davies PS, Strain JJ, McKenna PG, Mahoney CA, White JA, Stewart CM, Kerr MJ. Daily energy expenditure in free-living children: comparison of heart-rate monitoring with the doubly labeled water $\left({ }^{2} \mathrm{H}_{2}{ }^{18} \mathrm{O}\right)$ method. Am I Clin Nutr 1992;56:343-352.

43. Luke A, Roizen NJ, Sutton M, Schoeller DA. Energy expenditure in children with Down syndrome: correcting metabolic rate for movement, J Pediatr 1994;125:829-838.

44. Sun MI, Gower BA, Nagy TR, Trowbridge CA, Dezenberg C, Goran MI. Total, resting and activity-related energy expenditures are similar in Caucasian and African-American children. Am J Physiol 1998;274:E232-E237. 
$$
44
$$ 
Chapter 3

\section{PHYSICAL ACTIVITY LEVEL MEASURED BY DOUBLY LABELED WATER AND ACCELEROMETRY IN CHILDREN}

Marije B. Hoos ${ }^{1}$, Guy Plasqui ${ }^{2}$, Willem-Jan M. Gerver ${ }^{1}$ and Klaas R. Westerterp ${ }^{2}$

From the department of Pediatrics ${ }^{1}$, Department of Human Biology ${ }^{2}$ University of Maastricht, the Netherlands

European Journal of Applied Physiology (in press). 


\section{ABSTRACT}

The present study investigated the use of a tri-axial accelerometer, Tracmor2, for the measurement of physical activity in children. Eleven children (age $6.9( \pm 2.2)$ years, body weight $19.5( \pm 5.3) \mathrm{kg}$ and height $112.3( \pm 14.4) \mathrm{cm}$ ) were studied. Total daily energy expenditure (TDEE) was measured by the doubly labeled water method over a two weeks period. In addition, basal metabolic rate (BMR) was determined by the ventilated hood system. Physical activity level (PAL) was defined as TDEE/BMR. Tracmor 2 was worn during the identical two weeks period throughout waking hours after which average counts/day were calculated. The average counts/day showed to be highly correlated to PAL values measured by doubly labeled water: $\mathrm{PAL}=1.15610^{-5} *$ counts $/$ day $+0.978(r=0.79, p$ $<0.01$ ). In conclusion, Tracmor 2 is a valid instrument to measure physical activity in children under free-living conditions. 


\section{INTRODUCTION}

Physical activity and physical fitness are important for health and development. Inactivity increases the risk of diseases associated with our modern lifestyle. Because physical inactivity in childhood has been found to continue into adulthood, the promotion of regular physical activity in children could serve as a preventive health strategy. Bringing about changes in habitual lifestyles requires an understanding of the current levels and patterns of physical activity.

The doubly labeled water (DLW) method is regarded as the 'gold standard' for the measurement of physical activity. It estimates physical activity under free-living conditions over a period of 1-2 weeks. However, labeled water is expensive, not easily available and cannot be used for the measurement of physical activity patterns. Accelerometers, validated against DLW, are a good alternative for the measurement of physical activity patterns.

Accelerometers register the occurrence and intensity of body movement. Two classes of accelerometers are described in literature: uni-axial and tri-axial accelerometers. Johnson et al. (1) validated the Caltrac device, which measures accelerations in one direction. Compared to the DLW method the Caltrac was not found to be accurate. Ekelund et al. (2) used a CSA activity monitor, which is also a uni-axial accelerometer, and found a good correlation between the accelerometer and DLW data. In contrast, Leenders et al. showed an underestimation of physical activity expressed as kcal/day measured by the CSA (3) and the Tritrac, a tri-axial accelerometer. Another tri-axial accelerometer, the Tracmor did prove to be a reliable tool for assessing physical activity in adults (4).

The present study validates the Tracmor2 in children. The Tracmor2 is, in contrast to the Tracmor used by Bouten et al. a much smaller and lighter device, which minimizes subject's discomfort. 


\section{SUBJECTS AND METHODS}

\section{Subjects and study design}

Eleven children in the age range of 3-12 years were selected. The children were healthy and free from any medical condition that could restrict their physical activity. The children visited the hospital early in the morning for basal metabolic rate (BMR) measurements. From that moment, the Tracmor 2 was worn for a period of two weeks. The evening preceding the BMR measurement the children received a dose of ${ }^{2} \mathrm{H}_{2}{ }^{18} \mathrm{O}$. During the two-weeks period, urine samples were collected and stored at $-20{ }^{\circ} \mathrm{C}$ until ${ }^{2} \mathrm{H}$ and ${ }^{18} \mathrm{O}$ enrichments were measured. Parents and children were informed about the study before informed consent was obtained. The study was approved by the Ethical Committee of the University Hospital Maastricht.

\section{Doubly labeled water and ventilated hood}

Estimating physical activity by DLW requires information about total daily energy expenditure (TDEE) and BMR. Total daily energy expenditure was measured by the doubly labeled water method according to the Maastricht protocol (5). A weighed dose of water with a measured enrichment of about 5 atom $\%{ }^{2} \mathrm{H}$ and 10 atom $\%{ }^{18} \mathrm{O}$ was ingested in the evening preceding the BMR measurement. This dose results in an initial excess body water enrichment of $150 \mathrm{ppm}$ for ${ }^{2} \mathrm{H}$ and $300 \mathrm{ppm}$ for ${ }^{18} \mathrm{O}$. A baseline urine sample was collected before dosing. Additional urine samples were collected in the mornings and evenings of days 1,8 and 15. Samples were analyzed on an isotope-ratio mass spectrometer (Optima; VG Isogas, Middlewich Cheshire, England).

The hydrogen isotope is eliminated from the body as water, while the oxygen isotope is eliminated as both water and carbon dioxide. The difference between the two elimination rates is therefore a measure of carbon dioxide production. Total daily energy expenditure was calculated, using Weir's equations (6), from carbon dioxide production assuming a respiratory quotient (RQ) of 0.85 .

BMR was measured using an open-circuit, ventilated hood system in the morning after an overnight fast. The subjects were asked to lie in supine position for 30 minutes. Gas analyses were made with a paramagnetic oxygen analyzer (Servomex type 500A, Crowborough Sussex, UK) and with an infrared carbon dioxide analyzer (Servomex type $500 \mathrm{~A}$ ), similar to the system described by Schoffelen et al. (7). Oxygen consumption and carbon dioxide production were calculated using the flow through the hood and the oxygen and carbon dioxide concentrations in the incoming and outgoing air. Weir's equations were used to calculate BMR (6). Knowing TDEE and BMR, physical activity level (PAL) can be calculated as: TDEE/BMR. 


\section{Accelerometer}

The Tracmor2 (Tracmor2, Philips Research, Eindhoven, The Netherlands), a tri-axial accelerometer, was worn for 2 weeks. The Tracmor 2 is a small $(7 \times 2.8 \times 0.8 \mathrm{~cm})$ and light (30 g) device, which is worn attached to an elastic belt at the back of the waist. The triaxial accelerometer calculates the sum of the rectified and integrated acceleration curves from the anteroposterior, mediolateral and vertical directions of the trunk. The integration period was set at $1 \mathrm{~min}$ and the final output is expressed as counts per minute (c.p.m.) (4).

The Tracmor2 was worn during waking hours, except while showering and during swimming. The parents of the children recorded the moments when the children woke up, put the Tracmor 2 on and off and went to bed. If the time during which they wore the device and the time spent sleeping did not add up to at least 22 hours, the day was excluded from the analysis (mean number of recorded days 11). Average daily counts were calculated.

\section{STATISTICS}

A linear regression analysis was performed for the PAL (TDEE/BMR) measured with the DLW method and the Tracmor2 (average counts/day) output.

\section{RESULTS}

Subject characteristics are given in table 3 a. The mean age of the children was $6.9( \pm 2.2)$ years, body weight was $19.5( \pm 5.3) \mathrm{kg}$ and height was $112.3( \pm 14.4) \mathrm{cm}$. Linear regression analysis resulted in the following equation for the calculation of PAL values (figure $3 \mathrm{a}$ ):

$$
\mathrm{PAL}=1.15610^{-5} * \text { Tracmor2 average counts/day. }+0.978(r=0.79, p<0.01)
$$

\section{DISCUSSION}

As our awareness of the effect of inactivity on health and development increases, so does the interest in methods to measure physical activity. Because physical inactivity in children continues into adulthood, prevention of inactivity is especially in this age group of great importance. When measuring physical activity, one has to be sure that the measurement does not interfere with the child's daily activities. Accelerometers are therefore a good alternative for the DLW method, which is considered to be the 'gold standard'.

The present study showed the Tracmor2 to be a valuable instrument for the evaluation of physical activity in children. Bouten et al. (4) compared activity counts from the Tracmor with energy expenditure in adult subjects. A correlation coefficient of $0.58(p<0.001)$ was found. The correlation improved to a value comparable to those of the present study $(0.73)$ 
Table 3a Subject characteristics.

\begin{tabular}{llllllll}
\hline $\begin{array}{l}\text { Subject } \\
\text { No. }\end{array}$ & $\begin{array}{l}\text { Age } \\
\text { (years })\end{array}$ & $\begin{array}{l}\text { Sex } \\
(\mathrm{M} / \mathrm{F})\end{array}$ & $\begin{array}{l}\text { Height } \\
(\mathrm{cm})\end{array}$ & $\begin{array}{l}\text { Weight } \\
(\mathrm{kg})\end{array}$ & $\begin{array}{l}\text { kCounts/ } \\
\text { day }\end{array}$ & $\begin{array}{l}\text { TDEE } \\
(\mathrm{M})\end{array}$ & $\begin{array}{l}\text { BMR } \\
(\mathrm{MJ})\end{array}$ \\
\hline 1 & 5.9 & $\mathrm{~F}$ & 100.3 & 18.0 & 30.7 & 5.06 & 3.69 \\
2 & 6.8 & $\mathrm{~F}$ & 103.8 & 15.0 & 34.3 & 5.45 & 4.40 \\
3 & 5.8 & $\mathrm{~F}$ & 95.9 & 12.3 & 39.9 & 5.07 & 3.49 \\
4 & 11.1 & M & 130.9 & 25.2 & 60.8 & 8.29 & 4.54 \\
5 & 6.6 & $\mathrm{~F}$ & 103.7 & 14.8 & 34.1 & 4.64 & 3.43 \\
6 & 3.4 & $\mathrm{~F}$ & 97.4 & 15.4 & 39.2 & 5.26 & 3.56 \\
7 & 8.3 & $\mathrm{~F}$ & 129.3 & 27.5 & 31.0 & 6.57 & 4.58 \\
8 & 5.9 & $\mathrm{~F}$ & 115.0 & 19.7 & 53.8 & 5.60 & 4.03 \\
9 & 4.9 & M & 101.7 & 16.7 & 48.3 & 6.25 & 4.00 \\
10 & 9.8 & M & 128.8 & 23.5 & 53.4 & 7.27 & 4.47 \\
11 & 7.1 & F & 128.6 & 26.4 & 58.7 & 7.57 & 4.64 \\
\hline
\end{tabular}

TDEE: Total daily energy expenditure; BMR: basal metabolic rate; M: male; F: female.

when counts were corrected for counts that were the results of vibrations produced by transportation. Because these vibrations are in Tracmor 2 removed by a low-pass filter, this correction is not necessary when using Tracmor2.

Two other studies in children describe the validation of an accelerometer. Johnson et al. did not find a relation between Caltrac and DLW data. Ekelund et al. found a correlation of 0.54 (2) between average activity counts and physical activity measured by DLW using the CSA. Another study in women by Leenders et al. did not find a relation between CSA and DLW data (3). Like Johnson et al., that study converted accelerometer output to $\mathrm{kcal} /$ day on the basis of an equation including age, height, weight and gender.

Besides the CSA the study showed the Tritrac, a tri-axial accelerometer, to underestimate physical activity. Also Tritrac output was converted to kcal/day with use of equations based on weight, height, sex and age. This means that the measurement of physical activity depends in addition to accelerometer output on subject characteristics.

The lower correlation found by Ekelund et al. compared to the present study can probably be contributed to the fact that Ekelund used the CSA accelerometer, which is a uni-axial accelerometer. This device only registers movements in the vertical plane in contrast to the Tracmor, which measures movements in three directions. 


\section{Figure 3a}

Physical activity levels (PAL= Total daily energy expenditure/basal metabolic rate) measured by the doubly labeled water technique plotted against the average daily Tracmor counts. The solid line represents the regression line: $P A L=1.15610^{-5}$. counts/day $+0.978(r=0.79, p<0.01)$.

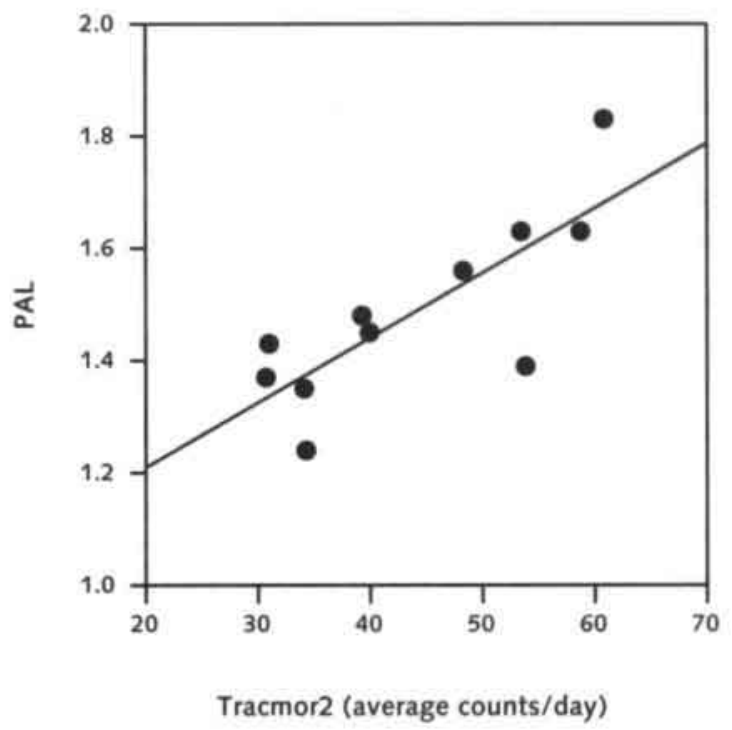

The position of attachment to the body can also influence accelerometer output. Ideally, several accelerometers are used, attached to different sites to the body, however this is very unpleasant for the subject. Therefore the Tracmor, CSA and Tritrac are attached to the waist, which is close to the center of gravity. The Caltrac was not attached to the waist, but to the hip.

When measuring physical activity it is important not to disturb the regular pattern of physical activity. Therefore it is important to minimize subject's discomfort. The Tracmor2 is worn around the waist attached to an elastic belt. Because the Tracmor2 is a small device it can be covered invisible with clothing. In addition, the Tracmor 2 is a light device compared to other accelerometers.

We conclude that because the Tracmor 2 can be used under free-living conditions, does not interfere with the child's habitual activity pattern and showed to be highly correlated to the DLW method, it may be considered as the most appropriate device for the assessment of physical activity in children. 


\section{REFERENCES}

1. Johnson RK, Russ J, Goran MI. Physical activity related energy expenditure in children by doubly labeled water as compared with the Caltrac accelerometer. Int i Obes 1998;22:1046-1052.

2. Ekelund E, Sjostrom M, Yngve A, Poortvliet E, Nilsson A, Froberg K, Wedderkopp N, Westerterp K. Physical activity assessed by activity monitor and doubly labeled water in children. Med Sci Sports Exerc 2000;33:275-281.

3. Leenders NY, Sherman WM, Nagaraja HN, Kien CL. Evaluation of methods to assess physical activity in free-living conditions. Med Sci Sports Exerc 2001;33:1233-1240.

4. Bouten CV, Verboeket-van de Venne WP, Westerterp KR, Verduin M, Janssen JD. Daily physical activity assessment: comparison between movement registration and doubly labeled water. J Appl Physiol 1996;81:1019-1026.

5. Westerterp KR, Wouters L, Van Marken-Lichtenbelt W. The Maastricht protocol for the measurement of body composition and energy expenditure with labeled water. Obes Res 1995:3:49-57.

6. Weir JB. New methods for calculating metabolic rate with special reference to protein metabolism. J Physiol 1949:109:1-9.

7. Schoffelen PFM, Westerterp KR, Saris WHM, Ten Hoor F. A dual-respiration chamber system with automated calibration. J Appl Physiol 1997;83:2064-2072. 
Chapter 4

\section{PHYSICAL ACTIVITY PATTERN OF CHILDREN ASSESSED BY TRI-AXIAL ACCELEROMETRY}

Marije B. Hoos ${ }^{1}$, Harm Kuipers ${ }^{2}$, Willem-Jan M. Gerver ${ }^{1}$ and Klaas R. Westerterp ${ }^{3}$

From the department of Pediatrics ${ }^{1}$, department of Movement Sciences ${ }^{2}$ and department of Human Biology ${ }^{3}$ University Maastricht, the Netherlands

Submitted for publication 


\section{ABSTRACT}

\section{Objectives}

Accelerometry was used to assess the relationship between physical activity level (PAL) and time spent on activities of various intensities in children.

\section{Methods}

Twenty children aged $8.6 \pm 3.3$ years wore a tri-axial accelerometer (Tracmor2) for two weeks. PAL was calculated with Tracmor2 output data. The fraction of time spent on activities with a given level of intensity (low, moderate, high) was calculated. The fractions of time spent on activities of different intensities were compared with previously obtained data for young adults and elderly persons.

\section{Results}

PAL showed an inverse relation with the percentage of time spent on low-intensity activities $(r=0.76 ; p<0.0001)$ and a positive relation with the percentage of time spent on highintensity activities $(r=0.93 ; p<0.0001)$. The fraction of time spent on low-intensity activities was smaller in children than in young adults $(p<0.05)$ and elderly persons $(p<0.0001)$, while the fraction spent on high-intensity activities $(p<0.0001)$ was larger.

\section{Conclusions}

Our observations suggest that to obtain a higher PAL in children, children should be given the opportunities to perform high-intensity activities. In addition, children should be educated about the importance of regular physical activity to prevent inactivity in adulthood. 


\section{INTRODUCTION}

Physical inactivity becomes more and more a characteristic of our modern way of life. At the same time, obesity becomes an increasing problem among adults and even among children (1). Because it still remains unclear how much of the increase in obesity is attributable to an inactive lifestyle, there is a growing interest in the measurement of physical activity.

In the Netherlands, ten percent of the children between ages 5 and 11 are obese (2) and obesity in childhood is predictable for obesity at adult age (3-5). Therefore the prevention of physical inactivity should begin in early life. However bringing about changes in the habitual lifestyle of children requires an understanding of their current levels and patterns of activity.

Physical activity can be assessed in different ways. With use of the doubly labeled water (DLW) method, physical activity can be measured over a 1-2 weeks period, without interfering with the subject's natural activity behavior (6). The technique is easy applicable and implies for the subject only the collection of some urine samples. The DLW method is regarded as the 'gold standard' for the validation of other instruments measuring physical activity. However a practical limitation of large-scale application of the DLW technique is the high costs. In addition, the DLW method can only be used to measure the average physical activity level. Accelerometers on the other hand are able to measure physical activity intensity and physical activity patterns, i.e. the time spent on activities of low (sitting), moderate (walking) and high-intensity (running) activities. The CSA (Computer Science and Applications Inc. monitor) and Tracmor have been validated against DLW and proven to be reliable tools for the assessment of physical activity $(7,8)$. The CSA is a uniaxial accelerometer. Uni-axial accelerometers measure the occurrence and intensity of movements in the horizontal plane (8). The Tracmor, a tri-axial accelerometer, registers movements in three dimensions (7).

The Tracmor has been used to measure physical activity patterns in adults $(7,9)$. These studies showed that spending more time on moderate-intensity activities and thereby reducing the time spent on low-intensity activities, is more effective in increasing overall activity levels than spending more time on high intensity activities. This is most likely explained by the fact that high-intensity activities are usually performed for a short period of time.

In children less is known about physical activity patterns. Although it is generally assumed that children are more active than adults, no studies exist comparing physical activity patterns of children to those of adults. The present study was aimed at the measurement of levels and patterns of physical activity in healthy children, using an accelerometer. 


\section{Figure $4 \mathrm{a}$}

Physical activity levels (PAL=Total daily energy expenditure/basal metabolic rate) as function of the fraction of daytime hours spent on low (circles), moderate (triangles) and high-intensity (closed circles) activities.

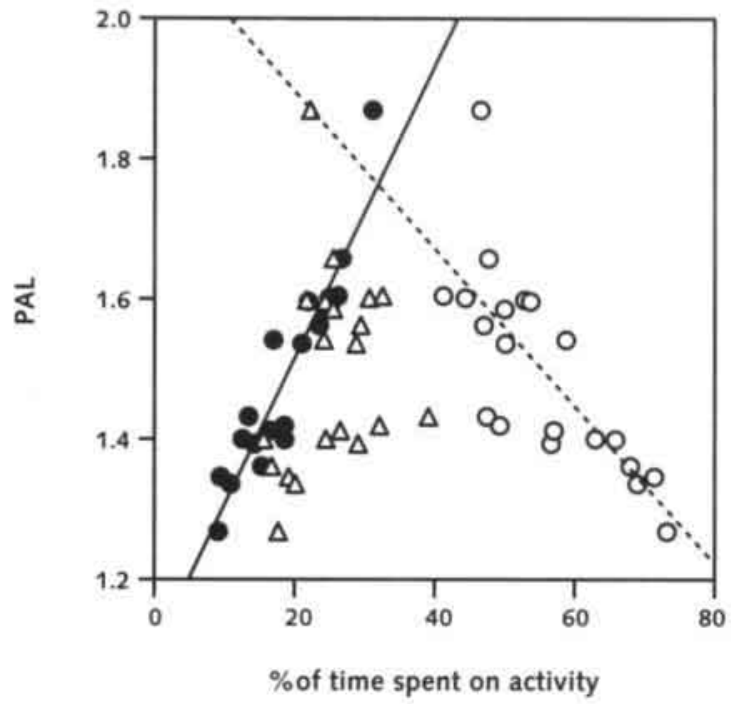

\section{RESULTS}

The fraction of time spent on low and high intensity activities was significantly correlated to $\operatorname{PAL}(r=0.76 ; p<0.0001$ and $r=0.93 ; p<0.0001$, respectively), whereas the fraction of time spent on moderate intensity activities was not significantly correlated to PAL (figure $4 \mathrm{a}$ ).

Children spend $56 \%$ of their time on low-intensity activities, $25 \%$ on moderate intensity activities and $19 \%$ on high intensity activities. This activity pattern was compared to previously published activity patterns of adults (7) and the elderly (10). The fraction of time spent on low intensity activities was significantly lower in children than in adults $(p<0.05)$ and elderly persons $(p<0.0001)$, while the fraction of time spent on high intensity activities was significantly higher in children than in adults and elderly persons $(p<0.0001)$ (table $4 a$ ). The fraction of time spent on moderate intensity activities was significantly higher in the children than in the elderly $(p<0.0001)$, though it did not differ significantly from that in adults (figure $4 \mathrm{~b}$ ).

\section{DISCUSSION}

Because of the negative effects that physical inactivity may have on health, the interest in methods to measure physical activity levels increases. Although an increasing number of health promotion programs aim to change activity patterns, few data are available about 


\section{Figure $4 \mathrm{a}$}

Physical activity levels (PAL=Total daily energy expenditure/basal metabolic rate) as function of the fraction of daytime hours spent on low (circles), moderate (triangles) and high-intensity (closed circles) activities.

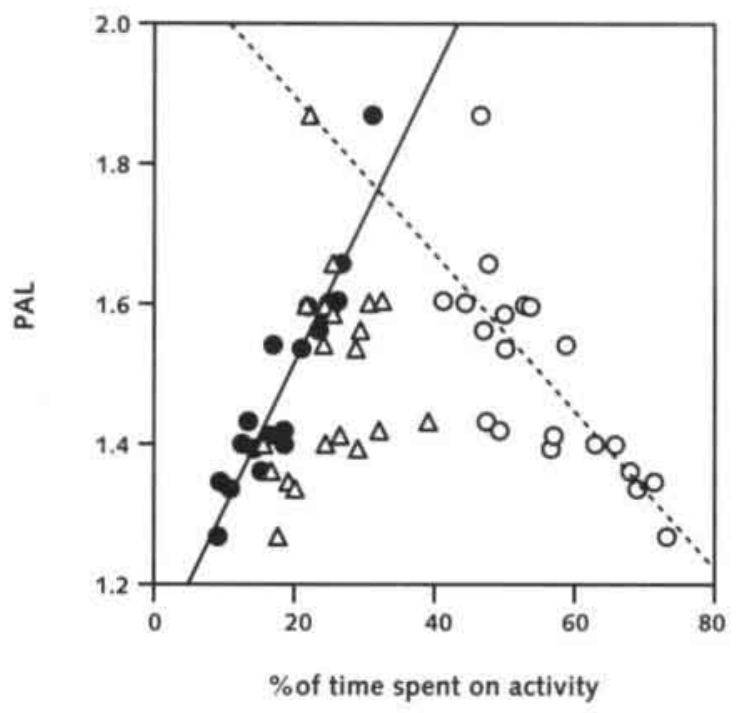

\section{RESULTS}

The fraction of time spent on low and high intensity activities was significantly correlated to PAL ( $r=0.76 ; p<0.0001$ and $r=0.93 ; p<0.0001$, respectively), whereas the fraction of time spent on moderate intensity activities was not significantly correlated to PAL (figure 4a).

Children spend $56 \%$ of their time on low-intensity activities, $25 \%$ on moderate intensity activities and $19 \%$ on high intensity activities. This activity pattern was compared to previously published activity patterns of adults (7) and the elderly (10). The fraction of time spent on low intensity activities was significantly lower in children than in adults $(p<0.05)$ and elderly persons $(p<0.0001)$, while the fraction of time spent on high intensity activities was significantly higher in children than in adults and elderly persons $(p<0.0001)$ (table $4 a)$. The fraction of time spent on moderate intensity activities was significantly higher in the children than in the elderly $(p<0.0001)$, though it did not differ significantly from that in adults (figure $4 \mathrm{~b}$ ).

\section{DISCUSSION}

Because of the negative effects that physical inactivity may have on health, the interest in methods to measure physical activity levels increases. Although an increasing number of health promotion programs aim to change activity patterns, few data are available about 
Table 4a Daily amount of sleep and activity time, physical activity level (PAL) and percentage of time spent on activities of low, moderate, and high intensity. Data for young adults and elderly persons obtained from previous studies $(7,10)$.

\begin{tabular}{lllllll}
\hline Variable (unit) & \multicolumn{2}{c}{ children } & \multicolumn{2}{c}{ adults } & \multicolumn{3}{c}{$\begin{array}{l}\text { elderly } \\
\text { mean }\end{array}$} & range & mean & range & & range \\
\hline Sleeping time (h/d) & 11.2 & $9.4-12.2$ & 8.3 & $6.7-10.5$ & 8.5 & $6.4-11.5$ \\
Activity time (h/d) & 12.3 & $11.1-14.7$ & 13.7 & $10.9-16.1$ & 14.4 & $11.7-17.2$ \\
PAL & 1.5 & $1.3-1.9$ & 1.77 & $1.5-2.0$ & 1.65 & $1.4-2.0$ \\
Low activity (\%) & 56 & $41-73$ & 65 & $52-82$ & 82 & $66-95$ \\
Moderate activity (\%) & 25 & $16-39$ & 25 & $11-36$ & 15 & $3-22$ \\
High activity (\%) & 19 & $9-31$ & 9 & $3-15$ & 4 & $1-12$ \\
\hline
\end{tabular}

the physical activity pattern and of the factors that affect the physical activity level, especially in children. The present study was aimed to assess the physical activity pattern in children using the Tracmor 2 accelerometer. Tracmor 2 has been proven to be a reliable method to measure physical activity patterns (7). Compared to other accelerometers, Tracmor2 is a small $(7 \times 2.8 \times 0.8 \mathrm{~cm})$ and light $(30 \mathrm{~g})$ device, which optimizes subject comfort (11).

In the present study among children it was found that the fraction of time spent on moderate intensity activities did not contribute significantly to PAL, unlike the fraction spent on low and high intensity activities. In contrast to the findings in adults, where the amount of overall physical activity can be increased by expanding the amount of time spent on activities of moderate intensity and reducing low-intensity activities (9), children should be stimulated to perform more high intensity activities because those activities belong to their habitual activity pattern.

Comparing physical patterns of children to those of adults and the elderly shows that the children spend more of their active time on high intensity activities. Young adults spend an average of $9 \%$ of their active time on high intensity activities, while the corresponding percentage among the elderly was found to be $4 \%$. In contrast, the present study found that children spend an average of $19 \%$ of their total active time on high intensity activities.

The difference in time spent on high intensity activities between children and adults reflects the different activity patterns among children, which are characterized by short, intermittent bouts of vigorous physical activity $(3,12-14)$. Probably because of their lower body weight it is easier for children to perform high intensity activities.

Even though children spend more time on high intensity activities, the PAL values we found among children were lower than those reported for young adults and the elderly. In addition to the fact that because of their lower body weight, high-intensity activities costs them less energy, this can probably be explained by the difference in the amount of sleep. 
The children slept an average of 11.2 hours a day, while adults have been found to sleep for an average of 8.3 hours, implying a longer total activity time for adults.

It would be of interest to measure the physical activity pattern of obese children using the Tracmor 2 and to compare those with the activity pattern of healthy children. Because we found PAL to be influenced by changes in low and high intensity activities in children, a decreased amount of time spent on high intensity activities is expected in obese children. If this would appear to be true, health programs should be aimed at educating parents of obese children to stimulate their children to perform more high intensity activities (playing outside) instead of low intensity activities (playing computer games).

Because we found a discrepancy between the activity patterns of children and young adults, health strategies should be aimed at preventing children's activity patterns from changing into those of the adult population (involving less high-intensity activity) by educating them about the importance of regular physical activities like walking or cycling.

In conclusion, our observations suggest that to obtain a higher PAL in children, children should be given the opportunities to perform high-intensity activities. In addition, children should be educated about the importance of regular physical activity to prevent inactivity in adulthood.

\section{Figure $4 b$}

Boxplots of the percentage of time spent on activities with low, moderate, and high intensity among children, young adults and elderly persons. Data for young adults and elderly persons were obtained from previous studies $(7,10)$.

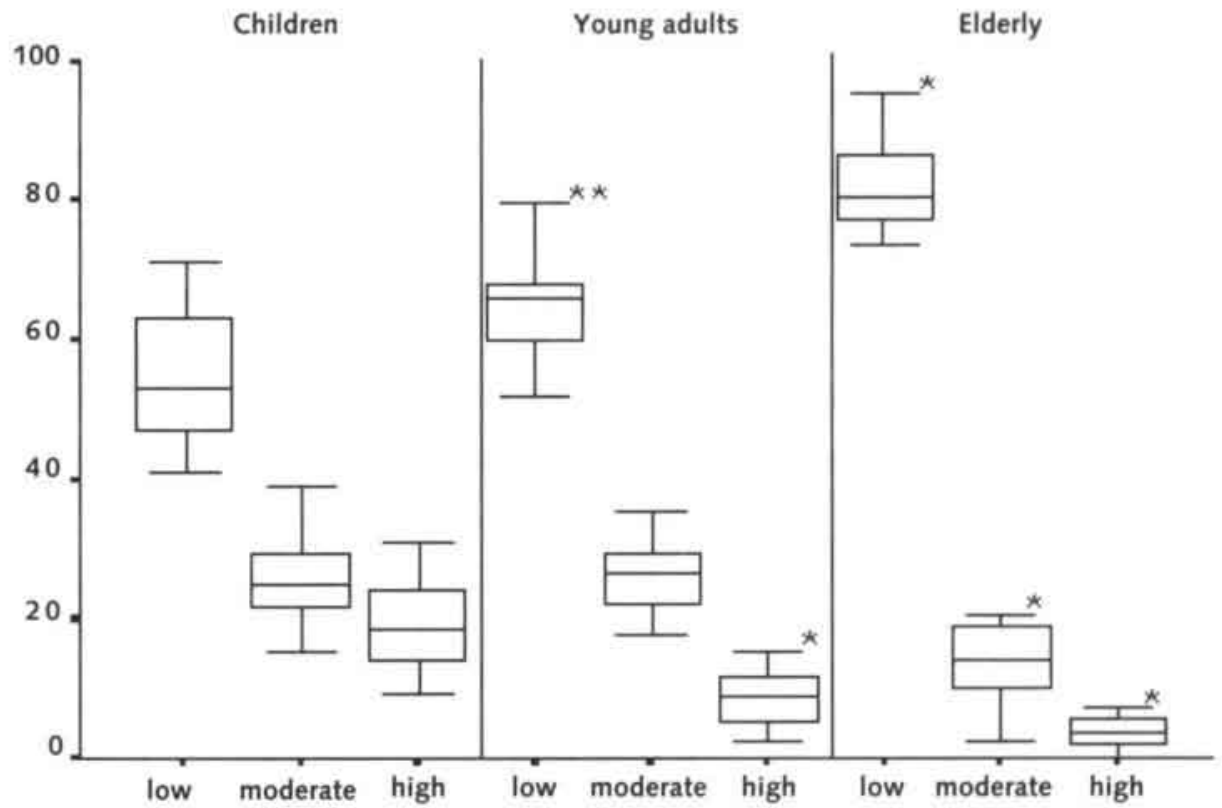

- significant difference between adults or elderly persons and children $p<0.0001$

* significant difference between children and adults $p<0.05$. 


\section{REFERENCES}

1. James PT, Leach R, Kalamara E, Shayeghi M. The worldwide obesity epidemic. Obes Res 2001:9 Suppl 4:S228-233.

2. Gezondheid en gedrag. Zoermeer, the Netherlands: Raad voor de Volksgezondheid en Zorg, 2002:1-152.

3. Molnar D, Livingstone B. Physical activity in relation to overweight and obesity in children and adolescents. Eur I Pediatr 2000;159 Suppl 1:\$45-55.

4. Janz KF. Dawson JD, Mahoney LT. Tracking physical fitness and physical activity from childhood to adolescence: the Muscatine study. Med Sci Sports Exerc. 2000;32:1250-1257.

5. Steinberger J, Moran A, Hong CP, Jacobs DR, Jr., Sinaiko AR. Adiposity in childhood predicts obesity and insulin resistance in young adulthood. I Pediatr 2001;138:469-473.

6. Westerterp KR, Wouters L, Van Marken-Lichtenbelt W. The Maastricht protocol for the measurement of body composition and energy expenditure with labeled water. Obes Res 1995;3:49-57.

7. Bouten CV, Verboeket-van de Venne WP, Westerterp KR, Verduin M, Janssen JD. Daily physical activity assessment: comparison between movement registration and doubly labeled water. $J$ Appl Physiol 1996;81:1019-1026.

8. Ekelund U, Sjostrom M, Yngve A, Poortvliet E, Nilsson A, Froberg K, Wedderkopp N, Westerterp K. Physical activity assessed by activity monitor and doubly labeled water in children. Med Sci Sports Exerc 2001;33:275-281.

9. Westerterp K. Pattern and intensity of physical activity. Nature 2001:410:539.

10. Meijer EP, Goris AHC, Wouters L. Westerterp KR. Physical activity as a determinant of the physical activity level in the elderly. Int J Obes 2001:25:935-939.

11. Westerterp KR. Physical activity assessment with accelerometers. Int J Obes 1999;23 Suppl 3:545-49.

12. Rowland TW. The biological basis of physical activity. Med Sci Sports Exerc 1998;30:392-399.

13. Bailey RC, Olson J, Pepper SL, Porszasz J, Barstow TJ, Cooper DM. The level and tempo of children's physical activities: an observational study. Med Sci Sports Exerc 1995;27:1033-1041.

14. Council for physical education for children. Physical activity for children: a statement of guidelines. Reston: VA: NASPE Publications, 1998. 
Chapter 5

\section{PHYSICAL ACTIVITY IN CHILDREN RECEIVING} GROWTH HORMONE THERAPY AS

MEASURED BY TRI-AXIAL ACCELEROMETRY

Marije B. Hoos ${ }^{1}$, Klaas R. Westerterp ${ }^{2}$, Harm Kuipers ${ }^{3}$ Lambert W.T. Schuwirth ${ }^{4}$ and WillemJan M. Gerver ${ }^{1}$

From the department of Pediatrics ${ }^{1}$, department of Human Biology ${ }^{2}$ department of Movement Sciences ${ }^{3}$ and department of Educational Development and Research ${ }^{4}$. University Maastricht, the Netherlands

Submitted for publication 


\section{ABSTRACT}

\section{Purpose}

Parents of children treated with growth hormone $(\mathrm{GH})$ frequently report to the pediatrician that their children have become more physically active. In the present study activity patterns of $\mathrm{GH}$-treated children were measured and compared to those of healthy controls.

\section{Methods}

Subjects were 25 children at the start of $\mathrm{GH}$ treatment (age $8.4 \pm 2.6$ years) and 19 age and gender matched controls (age $8.8 \pm 3.2$ ). Physical activity was assessed with a tri-axial accelerometer for movement registration over two separate 2 -week intervals, one before the start of $\mathrm{GH}$ treatment and one two weeks after the start of treatment. GH-treated subjects were categorized as poor responders (change in height over 1 year $<0.7$ SDS, $n=15$ ) or good responders (change in height over 1 year $>0.7$ SDS, $n=10$ ),

\section{Results}

Before therapy, good responders showed a significantly lower physical activity compared to healthy controls, spending significantly less time on high-intensity activities. This difference was disappeared two weeks after the start of therapy. Physical activity in poor responders was not significantly different from controls before and after two weeks of GH therapy.

\section{Conclusion}

Children who respond well to GH therapy (change in height $>0.7$ SDS) showed increased physical activity after two weeks of therapy as assessed with a tri-axial accelerometer. 


\section{INTRODUCTION}

Since the FDA approved the use of recombinant growth hormone $(\mathrm{rGH})$ in 1985, the number of prescriptions of growth hormone has risen dramatically (1). It was no longer only severely growth hormone deficient (GHD) patients who were treated, but also children suffering from partial GHD. The eligibility of patients for $\mathrm{GH}$ treatment is decided on the basis of anthropometric parameters and endocrine testing.

In pediatric patients growth hormone therapy is used to correct height deficit. However, it is also remarkable that parents frequently report to physicians that their child has become livelier after the start of treatment. This may be based on metabolic effects of $\mathrm{GH}$ as have been described in the literature. Gregory et al. for example found a significant increase in basal metabolic rate (BMR) (2) and total daily energy expenditure (TDEE) in children receiving $\mathrm{GH}$ therapy.

An increase in TDEE can be attributed to growth as well as to increased physical activity. Possible changes in this component of TDEE can be measured by accelerometry. Accelerometers measure the occurrence and intensity of body movements. The method is easy applicable and does not interfere with the child's daily activities. Two kinds of accelerometers are distinguished: one-axial and tri-axial accelerometers. One-axial accelerometers measure accelerations in one direction in contrast to tri-axial accelerometers, which measures accelerations of the body in three dimensions.

Since data about physical activity patterns in children receiving $\mathrm{GH}$ therapy are lacking, the present study investigated the short-term effect of $\mathrm{GH}$ on spontaneous physical activity. For this purpose, the Tracmor, a tri-axial accelerometer, which has been proven to be a reliable tool for the assessment of physical activity $(3,4)$ has been used. The patients were divided into two groups (good responders and poor responders) according to their response to $\mathrm{GH}$ therapy, to see whether the short-term changes in activity patterns were comparable between the two groups. In addition to the intensity of physical activity, Tracmor data have been used to calculate the fraction of time spent on a given activity at low, moderate or high levels of intensity $(3,4)$. 


\section{METHODS}

\section{Subjects}

Eligibility for therapy was based solely on one or more anthropometric criteria as visible in GH deficient patients: height SDS at start of treatment $<-2.5$ SDS, deviation from target height $>1.3$ SDS and growth in the year before treatment $>-0.25$ SDS. Additional, endocrine testing was performed (arginine, clonidine and sleep test) to measure maximum $\mathrm{GH}$ concentrations.

To minimize the influence of environmental factors, healthy controls were selected from friends or relatives of the patients living in the same neighborhood. They were measured simultaneously with the patients, but did not receive $\mathrm{GH}$ therapy. Parents and children were informed about the study and written informed consent was obtained. The study was approved by the Ethical Committee of the University hospital Maastricht.

Twenty-five children started GH therapy of whom, 19 had a height below -2.5 SDS, 21 deviated more than 1.3 SDS from their target height and 9 children showed a deviating growth. All patients were prepubertal by physical examination. Two control patients were aiready pubertal

\section{Study design}

The Tracmor was worn twice (M1 and $M 2$ ) during a two weeks period, before the start of therapy in the patients and during weeks three and four of this therapy. The children received $0.7 \mathrm{mg} \mathrm{hGH} / \mathrm{m}^{2} /$ day (Humatrope $($ ). Two girls with Turner syndrome received 1.3 $\mathrm{mg} \mathrm{hGH} / \mathrm{m}^{2} /$ day (Humatrope $\left({ }^{\circledR}\right)$, in accordance with Dutch treatment criteria. After one year, growth was evaluated and expressed as z-scores (SDS) (5). The difference in SDS $\left(S_{\text {tiyear }}-\right.$ SDS $\left._{\text {to }}\right)$ was used to divide the patient group into good and poor responders. A change in SDS > 0.7 was considered to be a good response, based on the mean response to $\mathrm{GH}$ therapy found in the study by Ranke et al. (6).

\section{Physical activity}

The physical activity was assessed with the help of a tri-axial accelerometer for movement registration (Tracmor, Philips Research, Eindhoven, The Netherlands). The Tracmor is a small device $(7 \times 2.8 \times 0.8 \mathrm{~cm})$, which is worn on a belt at the back of the waist. The tri-axial accelerometer calculates the sum of the rectified and integrated acceleration curves from the anteroposterior, mediolateral and vertical directions of the trunk. The integration period was set at $1 \mathrm{~min}$ and the final output is expressed as counts per minute (c.p.m.) (3).

The Tracmor was worn during waking hours, except while showering and during swimming. The parents of the children recorded in a log the times when the children woke up. when they put the Tracmor on and off and when they went to bed. If the sum of the 
time during which the device was worn and the duration of sleep was less than 22 hours, the day was excluded from the analysis (mean number of recorded days was 11).

Activities were defined at three intensity levels, as described before $(3,4)$, Low-intensity, associated with an accelerometer output $\leq 200$ c.p.m, represents lying, sitting and standing. Moderate-intensity, associated with an accelerometer output ranging from 200 to 500 c.p.m, includes walking at a velocity of $1.5-2.0 \mathrm{~km} / \mathrm{h}$. High-intensity activities are associated with an accelerometer output $\geq 500$ c.p.m. The fraction of time spent at a given intensity level was calculated as the time spent at this intensity level divided by total activity time.

\section{STATISTICS}

Tracmor data were expressed as counts/min, mean Tracmor counts per day were divided by the time during which the device was worn, to correct for possible differences in activity time. For each group of children, a paired t-test was used to see if there was a significant difference in the Tracmor data before and after two weeks of therapy. The treated groups were compared with each other and with the control group using an independent t-test.

\section{RESULTS}

The mean growth response after one year for the entire growth hormone treatment group $(n=25)$ was +0.59 SDS $( \pm 0.45)$, while the change in SDS in the control group was +0.02 $( \pm 0.21)$. On the basis of the response to $\mathrm{GH}$ therapy, three groups could be distinguished:

- control group $(n=19)$

(mean age $8.8 \pm 3.2$ years, weight $28.1 \pm 11.0 \mathrm{~kg}$, height $1.3 \pm 0.2 \mathrm{~m}$ );

- patient group with a response to GH therapy $<0.7$ SDS/year $(n=15)$ (mean age $9.7 \pm 2.4$ years, weight $23.6 \pm 5.9 \mathrm{~kg}$, height $1.2 \pm 0.1 \mathrm{~m}$ );

- patient group with a response to GH therapy $>0.7$ SDS/year $(n=10)$ (mean age $6.5 \pm 1.7$ years, weight $17.1 \pm 7.4 \mathrm{~kg}$, height $1.1 \pm 0.09 \mathrm{~m}$ ).

Although the mean age of the two patient groups did not differ significantly from that of the controls, the children with a poor response to $\mathrm{GH}$ therapy were significantly older than the good responders $(9.7 \pm 2.4$ versus $6.5 \pm 1.7$ years; $p<0.01)$. The number of recorded days did not significantly differ between the two measurement periods.

As can be seen in table $5 \mathrm{a}$, the number of Tracmor counts/min before the start of the GH therapy was significantly lower in the good responders than in the controls $(p<0.05)$. After two weeks of therapy, this difference had disappeared, because of a significant increase in the number of counts/minute among the good responders $(p<0.05)$ (table $5 a)$.

The proportion of time the three groups spent on low, moderate and high intensity activity is listed in table $5 \mathrm{a}$. This shows that before therapy, good $\mathrm{GH}$ therapy responders spent less 
Table 5a Tracmor data output of three subject groups: controls, poor GH responders (change in height $<0.7$ SDS) and good GH responders (change in height $>0.7$ SDS).

\begin{tabular}{|c|c|c|c|c|c|c|c|}
\hline & \multicolumn{2}{|c|}{ Controls } & \multicolumn{2}{|c|}{ Poor responders } & \multicolumn{3}{|c|}{ Good responders } \\
\hline & M1 & $M 2$ & M1 & $M 2$ & M1 & & $M 2$ \\
\hline Tracmor & $61^{A}$ & 57 & $67^{A}$ & 64 & $48^{8}$ & * & 55 \\
\hline (Counts/min) & (17) & (17) & (16) & (15) & (11) & & (12) \\
\hline Low activity & 56 & 56 & 56 & 58 & 62 & & 58 \\
\hline$(\%)$ & (10) & (12) & (11) & (11) & (8) & & (11) \\
\hline Moderate activity & 25 & 25 & 23 & 23 & 25 & & 26 \\
\hline$(\%)$ & (6) & (6) & (5) & (5) & (6) & & (6) \\
\hline High activity & $19^{A}$ & 19 & $21^{A}$ & 19 & $13^{8}$ & • & 17 \\
\hline$(\%)$ & (7) & (8) & (7) & (7) & (5) & & (7) \\
\hline
\end{tabular}

$M 1=$ first measurement period, before start of GH treatment in the patients.

M2 = second measurement period, two weeks after the start of GH treatment in the patients

Values are means (sd). Tracmor data were expressed as counts/min, mean Tracmor counts per day were divided by the time during which the device was worn, to correct for possible differences in activity time.

A paired t-test was used to see if there was a significant difference in the Tracmor data before and after two weeks of therapy (stars $\left({ }^{*} p<0.05\right.$.) denote within groups differences compared to baseline values).

An independent $t$-test was used to test the difference between the three different patient groups (uppercase letters represent between groups differences, means with different letter superscripts are significantly different $p<0.05$ ).

time on high-intensity activities than controls and poor responders $(p<0.05, p<0.01$ respectively). After two weeks of $\mathrm{GH}$ therapy, there was no longer a significant difference between the three groups. Good GH therapy responders showed a significant increase in high-intensity activities ( $p<0.05$ ). Tracmor data of poor $\mathrm{GH}$ responders did not significantly differ from controls before as well as after start of therapy. Excluding the Turner patients did not influence the outcome of the results.

A comparison of the two patient groups in terms of the maximum growth hormone values found during the endocrine tests revealed no significant difference between the good and poor responders as regards the maximum $\mathrm{GH}$ concentrations found during the sleep, arginine or clonidine tests. 


\section{DISCUSSION}

Growth hormone is known to have an anabolic effect, which is associated with increased energy expenditure (7). Although it is a general experience of pediatricians that children become more active after the introduction of GH therapy, Gregory et al. were unable to demonstrate an increase in activity. The measured increase in TDEE in their study reflected the increase in BMR (2).

In the present study, the children were divided into two groups according to their response to growth hormone therapy. Before the start of $\mathrm{GH}$ therapy, good $\mathrm{GH}$ therapy responders showed a lower number of Tracmor counts per minute and spent less time on high-intensity activities. The observed difference had disappeared after two weeks of GH therapy. This means that children with a good response on $\mathrm{GH}$ therapy were less physical active than healthy controls until GH was supplemented. The lower amount of activity before start of treatment might be partly explained by an impaired erythropoiesis, as was demonstrated in GHD adults (8). Erythropoiesis increases during $\mathrm{GH}$ therapy, which may lead to an increase in oxygen capacity and thereby contribute to an improved exercise performance capacity ( 8 , 9). In addition an increase in plasma volume and total blood volume, as was measured in $\mathrm{GH}$ deficient adults on $\mathrm{GH}$ therapy $(8,10)$, might contribute to an increase in $\mathrm{VO}_{2 \max }(11)$.

However, as the present study showed, the amount of spontaneous physical activity differed between good and poor responders. In contrast to the good responders, poor responders were comparable to controls before start of $\mathrm{GH}$ treatment. $\mathrm{GH}$ therapy did not influence their activity patterns. Probably, in these children their retarded growth was not based on growth hormone deficiency. The present results show that additional exogenous $\mathrm{GH}$ therapy does not influence activity levels in these children in contrast to the good responders in which $\mathrm{GH}$ therapy causes an increase in growth and physical activity. Our finding in poor responders might explain the results on activity found by Gregory et al. (2). This study found an increase in TDEE, which reflected the increase in BMR. Perhaps the heterogeneity of the patient group in their study in terms of the severity of GH deficiency could explain why the average effect of $\mathrm{GH}$ treatment on activity was not significantly different.

The effect of $\mathrm{GH}$ therapy on activity was observed over a relatively short period of time because metabolic effects of $\mathrm{GH}$ therapy become apparent soon after its start $(10,12)$, as was confirmed in the present study. The good responders adapted similar activity levels as their control counterparts after two weeks of GH supplementation. However, it would have been of interest to measure physical activity after one year of therapy to see if the increase in physical activity in the good responders was maintained. Unfortunately this was not possible because of practical limitations and should be subject of future studies.

In the present study, intensity of physical activity was measured using a tri-axial accelerometer, which is a non-invasive method to measure activity under free-living conditions. It confirmed the increase in activity reported by some parents after the introduction of $\mathrm{GH}$ therapy. Good responders were less active than controls before the introduction of GH therapy, which was normalized two weeks after the start of therapy. In 
the poor responders group, $\mathrm{GH}$ therapy had no effect on activity. The increase in physical activity in responders was mainly attributable to an increase in high-intensity activities.

\section{ACKNOWLEDGEMENTS}

We would like to thank J.M.J. Sijstermans and P.M.V.M. Theunissen of the Atrium hospital Heerlen for their contributions to this study. 


\section{REFERENCES}

1. Grumbach KM, Bin-Abbas HS, Kaplan SL. The growth hormone cascade: progress and long term results of growth hormone treatment in growth hormone deficiency. Horm Res 1998;49:41-57.

2. Gregory JW, Greene SA, Jung RT, Scrimgeour CM, Rennie M. Changes in body composition and energy expenditure after six weeks' growth hormone treatment. Arch Dis Child 1991;66:598-602.

3. Bouten CV, Verboeket-van de Venne WP, Westerterp KR, Verduin M, Janssen JD. Daily physical activity assessment: comparison between movement registration and doubly labeled water. I Appl Physiol 1996;81:1019-1026.

4. Meijer EP, Goris AHC, Wouters L, Westerterp KR. Physical activity as a determinant of the physical activity level in the elderly. Int J Obes 2001;25:935-939.

5. Gerver WJM, de Bruin R. Paediatric Morphometrics, A reference manual. (second extended edition) ed. Maastricht: Universitaire pers Maastricht, 2001.

6. Ranke $M B$, Guilbaud $O$. Growth response in prepubertal children with idiopathic growth hormone deficiency during the first two years of treatment with human growth hormone. Analysis of the Kabi Pharmacia International Growth Study. Acta Paediatr Scand Suppl 1991;379:109-115.

7. Cowan FJ, Evans WD, Gregory JW. Metabolic effects of discontinuing growth hormone treatment. Arch Dis Child 1999;80:517-523.

8. Christ ER, Cummings MH, Westwood NB, Sawyer BM, Pearson TC, Sonksen PH, Russell-Jones $\mathrm{DL}$. The importance of growth hormone in the regulation of erythropoiesis, red cell mass, and plasma volume in adults with growth hormone deficiency. I Clin Endocrinol Metab 1997;82:2985-2990.

9. Vihervuori $E$, Virtanen $M$, Koistinen $H$, Koistinen $R$, Seppala $M$, Siimes $M A$. Hemoglobin level is linked to growth hormone-dependent proteins in short children. Blood 1996;87:2075-2081.

10. Moller J, Frandsen E, Fisker S, Jorgensen JO, Christiansen JS. Decreased plasma and extracellular volume in growth hormone deficient adults and the acute and prolonged effects of GH administration: a controlled experimental study. Clin Endocrinol (Oxf) 1996;44:533-539.

11. Sawka MN, Convertino VA, Eichner ER, Schnieder SM, Young AJ. Blood volume: importance and adaptations to exercise training, environmental stresses, and trauma/sickness. Med Sci Sports Exerc 2000:32:332-348.

12. Copeland KC, Nair KS. Acute growth hormone effects on amino acid and lipid metabolism. I Clin Endocrinol Metab 1994;78:1040-1047. 
Chapter 6

\section{ENDURANCE TIME AND GRIP STRENGTH IN CHILDREN RECEIVING GROWTH HORMONE}

\section{THERAPY}

Marije B. Hoos ${ }^{1}$, Carlo Theunissen², Lambert W.T Schuwirth ${ }^{3}$, Klaas R. Westerterp ${ }^{4}$, Raymond A.M.G. Donckerwolcke ${ }^{1}$ and Willem-Jan M. Gerver ${ }^{1}$

From the department of Pediatrics', University of Maastricht, department of Physical Therapy ${ }^{2}$, University hospital Maastricht, department of Educational Development ${ }^{3}$ and Research, University of Maastricht, the Netherlands, department of Human Biology ${ }^{4}$. University of Maastricht, the Netherlands

Submitted for publication 


\section{ABSTRACT}

\section{Aim}

To see if there is an increase in endurance time and grip strength in children receiving growth hormone $(\mathrm{GH})$ therapy.

\section{Methods}

Subjects were 27 children starting $\mathrm{GH}$ treatment for medical treatment (age $8.8 \pm 2.8$ years) and 22 matched controls (age $8.5 \pm 3.2$ ). Endurance time on a treadmill and grip strength were measured before and during one year of $\mathrm{GH}$ therapy. In addition, height, weight and total body water (TBW) were measured. After one year of therapy GH-treated subjects were categorized as poor responders (change in height $<0.7$ SDS) or good responders (change in height $>0.7$ SDS).

\section{Results}

Only in the good responders there was a significant increase in endurance time. Height and TBW were both strongly correlated to the endurance time in the controls. Although significant, this relation was weaker in the patient groups. Grip strength increased in all three groups and was significantly correlated to weight and TBW with comparable Rsquares.

\section{Conclusions}

After one year of $\mathrm{GH}$ therapy, endurance time had increased in children with a good response on $\mathrm{GH}$ therapy. $\mathrm{GH}$ caused an additional effect on endurance time besides height and TBW. Grip strength had also increased, but no more than in an age matched group of healthy children. 


\section{INTRODUCTION}

Growth hormone $(\mathrm{GH})$ has been used for 40 years to promote linear growth in $\mathrm{GH}$ deficient children. Treatment is usually being stopped when final height is reached. However, $\mathrm{GH}$ also has a metabolic effect, reflected in an increase in fat-free mass and energy expenditure $(1,2)$. In $\mathrm{GH}$-deficient adults, these metabolic effects are the only reason to supply $\mathrm{GH}$.

Additionally, effects on cardiac function have also become clear in this patient group (3). $\mathrm{GH}$-deficient adults were found to have impaired cardiac function $(4,5)$, which improves after the introduction of $\mathrm{GH}$ therapy $(4,6-8)$. In addition to improved cardiac function, increased exercise tolerance $(9,10)$ and muscle strength have been reported, which might improve physical fitness and the ability to perform everyday task. Because of these potential benefits for physical performance capacity, the International Olympic Committee (IOC) has put $\mathrm{GH}$ on the doping list.

The present study examined the effect of $\mathrm{GH}$ therapy on physical fitness and grip strength in children by means of an exercise test and a handgrip test. It was expected that the endurance time (Tend) and grip strength (Grip) increased in comparison with healthy controls, especially in children who showed a good response on GH therapy. Height, weight and body composition were measured to explain possible changes in Tend and Grip. 


\section{METHODS}

\section{Subjects}

The children were considered eligible for $\mathrm{GH}$ therapy if they showed at least one of the following signs of $\mathrm{GH}$ deficiency:

- height SDS at start of treatment $<-2.5$ SDS;

- deviation from target height >1.3 SDS;

- growth in the year before treatment $>-0.25$ SDS, and

- low GH concentrations in an arginine and clonidine provocative test. The endocrine tests were not decisive for therapy.

The study included 27 children with an average age of $8.8( \pm 2.8)$ years who were starting $\mathrm{GH}$ treatment, while 22 healthy children aged $8.5( \pm 3.2)$ years were included as controls. The controls were friends or relatives of the patients, living in the same neighborhood. They were measured simultaneously with the patients, but did not receive GH therapy. Parents and children were informed about the study before informed consent was obtained. The study was approved by the Ethical Committee of the University hospital Maastricht.

\section{Study design}

Endurance time and grip strength were measured immediately prior to the treatment, at 2 and 6 weeks and at 3, 6, 9 and 12 months after start of therapy (Tend ${ }_{t 1} \ldots$ Tend $_{t 7}$ and Grip $_{\mathrm{t} 1} \ldots$ Grip $_{\mathrm{t}}$ ). All measurements were performed by the same investigator $(\mathrm{MH})$. $\mathrm{GH}$ supplementation was $0.7 \mathrm{mg}$ Humatrope ${ }^{\otimes} / \mathrm{m}^{2} /$ day. Two girls with Turner syndrome received $1.3 \mathrm{mg}$ Humatrope $\% / \mathrm{m}^{2} /$ day, in accordance with Dutch treatment criteria. After one year, growth was evaluated and expressed as standard deviation scores (SDS) (11). The difference in SDS $\left(\mathrm{SDS}_{t 7}-\mathrm{SDS}_{\mathrm{t1}}\right.$ ) was used to divide the patient group into good and poor responders. A change in SDS $>0.7$ was regarded as a good response, based on the mean response to $\mathrm{GH}$ therapy found in the study by Ranke et al. (12).

\section{Treadmill test}

Treadmill exercise testing was performed using the Bruce treadmill walking protocol to voluntary exhaustion on a Jaeger LE2000 treadmill (Erich Jaeger, Höchberg, Germany). The Bruce walking protocol consists of seven 3-minute stages.

- Stage $1: 2.74 \mathrm{~km} / \mathrm{h}$ at a slope of $10 \%$;

- Stage 2: $4.02 \mathrm{~km} / \mathrm{h}$ at a slope of $12 \%$;

- Stage 3: $5.47 \mathrm{~km} / \mathrm{h}$ at a slope of $14 \%$; 
- Stage $4: 6.76 \mathrm{~km} / \mathrm{h}$ at a slope of $16 \%$;

- Stage 5: $8.05 \mathrm{~km} / \mathrm{h}$ at a slope of $18 \%$;

- Stage $6: 8.85 \mathrm{~km} / \mathrm{h}$ at a slope of $20 \%$;

- Stage 7: $9.66 \mathrm{~km} / \mathrm{h}$ at a slope of $22 \%$ (13).

The children were not allowed to use the guardrails, except for the children younger than 6 years, and during a change stage, in order to maintain balance. They were encouraged to push themselves to maximum performance. The test was terminated when the children indicated they really wanted to stop, despite encouragement. Maximum endurance time was recorded (Tend).

\section{Grip strength}

Grip strength (Grip $\mathrm{t}_{\mathrm{t}}$ to Grip $\mathrm{t}_{\mathrm{t}}$ ), the isometric muscle force of the hand and forearm, was measured in the dominant hand with a hand-held dynamometer (JAMAR) adjusted for grip size. Measurements were performed three times, after which mean values were calculated. To elicit maximum effort, verbal encouragement was given during the performance of each test.

\section{Body composition}

Total body water (TBW) was measured with the stable isotope of hydrogen. The water is labeled on the hydrogen atom. Before the administration of the dose a background sample was taken to determine the natural abundance of the urine. The children drank the water in the evening before they went to bed. The other morning a urine sample was taken after the first voiding. In this urine sample the concentration label was determined. The calculation of the total body water is as follows:

$$
\mathrm{C}_{1} \cdot \mathrm{V} 1=\mathrm{C}_{2} \cdot \mathrm{V} 2
$$

$\mathrm{C} 1$ = the concentration of the tracer in the ingested fluid

$\mathrm{V} 1$ = the volume of the dose

$\mathrm{C} 2$ = the concentration of the tracer in the sample

V2 = distribution volume in the body

Due to the exchange of the label with non-aqueous substances in the body, V2 has to be divided by 1.04 to determine TBW.

The two first measurements were performed at the hospital to teach the parents the procedure. The children visited the hospital before their habitual bedtime. First the baseline urine was taken, whereafter the deuterium was ingested. The bottle which contained the deuterium was rinsed thoroughly, to be sure all water was ingested. The following morning the children returned to the hospital and a second urine sample was collected. 
Because the hydration of the fat free mass, which in adults is assumed to be $73 \%$ is in children age-dependent (14) the variable TBW was used for analyzing the effect of TBW on Tend and Grip.

\section{STATISTICS}

Children for whom baseline or one-year data were missing were excluded from the analysis. Other missing values were supplemented using the mean value of the preceding and subsequent measurements. If there were more than two missing values, the patient's data were excluded. Baseline and one-year values were compared between the different groups using an unpaired t-test. A one-factor ANOVA of repeated measures was performed for each group on Tend ${ }_{t 1} \ldots$ Tend $_{t 7}$ and Grip ${ }_{t 1} \ldots$ Grip ${ }_{t 7}$ to see if there was a significant change during the treatment year. On significant outcomes, a Scheffe post hoc analysis was used to determine the significant differences.

Regression analyses were performed per group on data of all time points to evaluate the effect of height and TBW on Tend and TBW and weight on Grip.

\section{RESULTS}

Of the children who started treatment, three were excluded because of missing baseline or final values. One child (and the corresponding control) stopped because of recurrence of a pituitary tumor. A further three poor responders and three controls had to be excluded from the handgrip analysis because of missing data. Anthropometric baseline data are given for all children in whom Tend was measured (table 6a). Mean height (expressed as SDS or cm), weight and age of the children for whom Tend $(n=49)$ was obtained did not differ from those of the group of children for whom grip strength was obtained $(n=43)$.

On the basis of the response to $\mathrm{GH}$ therapy, three groups could be distinguished:

- control group ( $n=22$ ) (mean age $8.5 \pm 3.1$ );

- patient group with a response to $\mathrm{GH}$ therapy $<0.7$ SDS/year $(n=16)$ (mean age $10.4 \pm$ 2.4);

- patient group with a response to $\mathrm{GH}$ therapy $>0.7$ SDS/year $(n=11)$ (mean age 6.4 \pm 1.2 ).

The division of the controls into two groups on the basis of the response to GH therapy of their age matched control (to exclude the differences in age) did not show a change in results, therefore the results of the control group were taken together.

Poor responders were significantly older than good responders and controls. Height expressed as SDS was significantly lower in both patient groups, before as well as after therapy, compared to controls (table 6a). 
There was no difference in height (expressed in centimeters) between controls and poor responders before and after therapy. Good responders were significantly shorter (height expressed as centimeter) than the other groups both before and after therapy. $\mathrm{GH}$ concentrations found in the arginine and clonidine test did not differ significantly between the two patient groups.

\section{Maximum endurance time (Tend):}

Figure $6 \mathrm{a}$ presents the changes in Tend over the year. Endurance time was significantly lower in the good responders than in both of the other groups, but after one year the good responders were comparable to controls. Poor responders showed longer endurance time, before and after the start of therapy, than good responders (table $6 \mathrm{a}$ ). Compared to controls, poor responders started at the same level, but after one year they showed longer endurance time.

The repeated measures ANOVA for Tend was only significant in the good responder group. Post-hoc analysis showed that this significance was accounted for by the increase after 6 months $(p<0.0001)$

Height as well as TBW were significantly correlated to Tend. However the relation was strongest for the controls (table $6 \mathrm{~b}$ ).

\section{Figure 6a}

Mean endurance time (Tend) and standarddeviation in controls (triangles), poor responders (circles) and good responders (filled circles), immediately prior to the treatment, at 2 and 6 weeks and at 3, 6, 9 and 12 months after start of therapy (Tend ${ }_{t 1}$ ... Tend $\left.{ }_{t}\right)$.

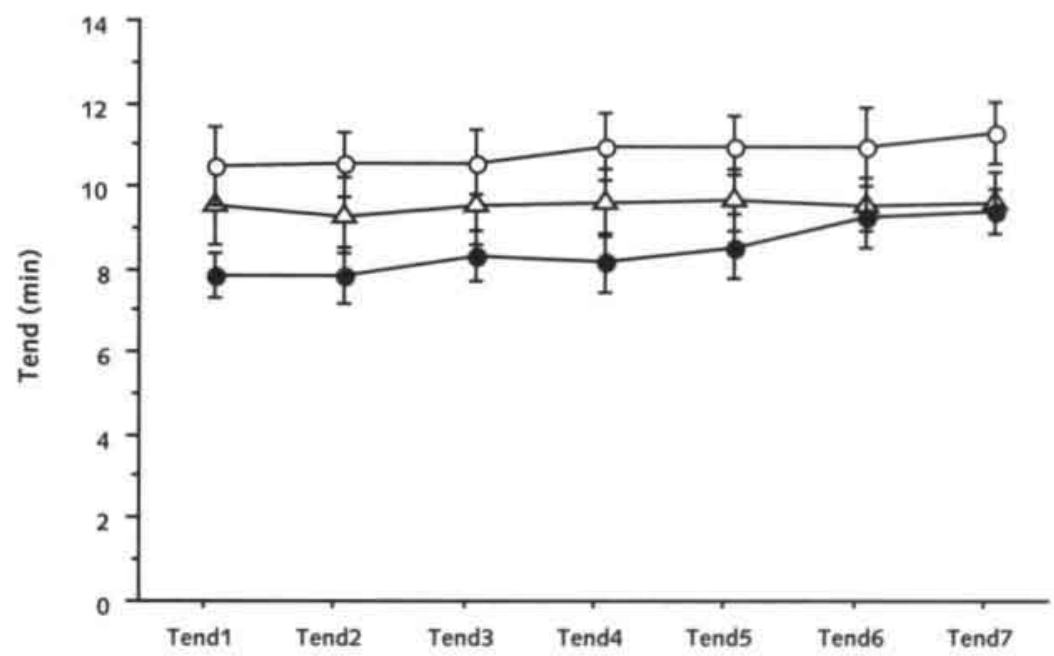


Table 6a Patient characteristics.

\begin{tabular}{|c|c|c|c|}
\hline & Controls & $\begin{array}{l}\text { Poor } \\
\text { Responders }\end{array}$ & $\begin{array}{l}\text { Good } \\
\text { Responders }\end{array}$ \\
\hline Age (years) & $8.5(0.7)^{A}$ & $10.4(2.4)^{B, E}$ & $6.4(1.2)^{B, F}$ \\
\hline Height SDS $_{t 1}$ & $-1.0(1.1)^{E}$ & $-2.8(1.0) F, A$ & $-3.7(0.7)^{F, B}$ \\
\hline Height $\operatorname{SDS}_{t}$ & $-0.9(1.1)^{C . E}$ & $-2.4(1.0)^{D}$ & $-2.6(0.7)^{F}$ \\
\hline [GH] mU/l arginine test & & 20.8 & 21.6 \\
\hline [GH] mU/I clonidine test & & 39.6 & 32.3 \\
\hline Tend $_{t 1}$ (min) & $9.6(2.2)^{A}$ & $10.6(1.8)^{E}$ & $7.9(1.0)^{B, F}$ \\
\hline Tend $_{17}$ (min) & $9.7(1.7)^{C}$ & $11.3(1.4)^{D, E}$ & $9.5(0.8)^{F}$ \\
\hline $\operatorname{Grip}_{\mathrm{t} 1}(\mathrm{~kg})$ & $13.7(5.9)^{C}$ & $14.2(5.8)^{c}$ & $7.4(2.1)^{\mathrm{D}}$ \\
\hline $\mathrm{Grip}_{\mathrm{t}}(\mathrm{kg})$ & $15.2(6.4)^{c}$ & $16.8(6.5)^{c}$ & $9.1(1.5)^{D}$ \\
\hline
\end{tabular}

${ }^{A B} p<0.05 ;{ }^{C D} p<0.01 ;{ }^{E F} p<0.0001$

$\mathrm{GH}=$ growth hormone

\section{Grip strength}

A significant increase in grip strength occurred in all three groups (figure $6 \mathrm{~b}$ ). Grip $\mathrm{t}_{11}$ and Grip $_{t 7}$ were significantly lower in the good responder group than in controls and poor responders. Grip was in all three groups correlated to weight. The weight of these correlations was for all three groups comparable (table $6 \mathrm{~b}$ ).

Table $6 \mathrm{~b}$ R-squares between Tend and height and TBW, and Grip and weight and TBW for controls, poor responders and good responders.

\begin{tabular}{lccc}
\hline & Controls & Poor responders & Good responders \\
\hline Tend- height & 0.55 & 0.08 & 0.31 \\
Tend -TBW & 0.49 & 0.04 & 0.29 \\
Grip -Weight & 0.71 & 0.76 & 0.52 \\
Grip -TBW & 0.67 & 0.74 & 0.63 \\
\hline
\end{tabular}




\section{DISCUSSION}

The present study evaluated the effect of GH therapy on endurance time and grip strength in children receiving $\mathrm{GH}$ therapy for medical treatment. The treated patients were divided into two groups according to their response to $\mathrm{GH}$ therapy. Prior to the treatment, the good responders (change in height $>0.7$ SDS) had a shorter endurance time, which increased significantly and matched the control values after one year of therapy. Grip strength increased in all three groups.

Because height was significantly correlated with endurance time, it may serve as a partial explanation of the increase in endurance time. An increase in height and leg length caused by $\mathrm{GH}$ therapy makes a walking test easier to perform. Cuneo et al. corrected exercise capacity for changes in muscle mass and found no alterations from baseline (15). This suggests that the increase in exercise performance is mainly caused by $\mathrm{GH}$-associated changes in muscle mass.

However the correlation between height and TBW and Tend was weaker for the good responders and even more weaker for the poor responders, which indicates that other factors must have influenced Tend.

\section{Figure $6 \mathrm{~b}$}

Mean Grip strength (Grip) and standarddeviation in controls (triangles), poor responders (circles) and good responders (filled circles), immediately prior to the treatment, at 2 and 6 weeks and at 3, 6, 9 and 12 months after start of therapy (Grip $\ldots$... Grip $t)$.

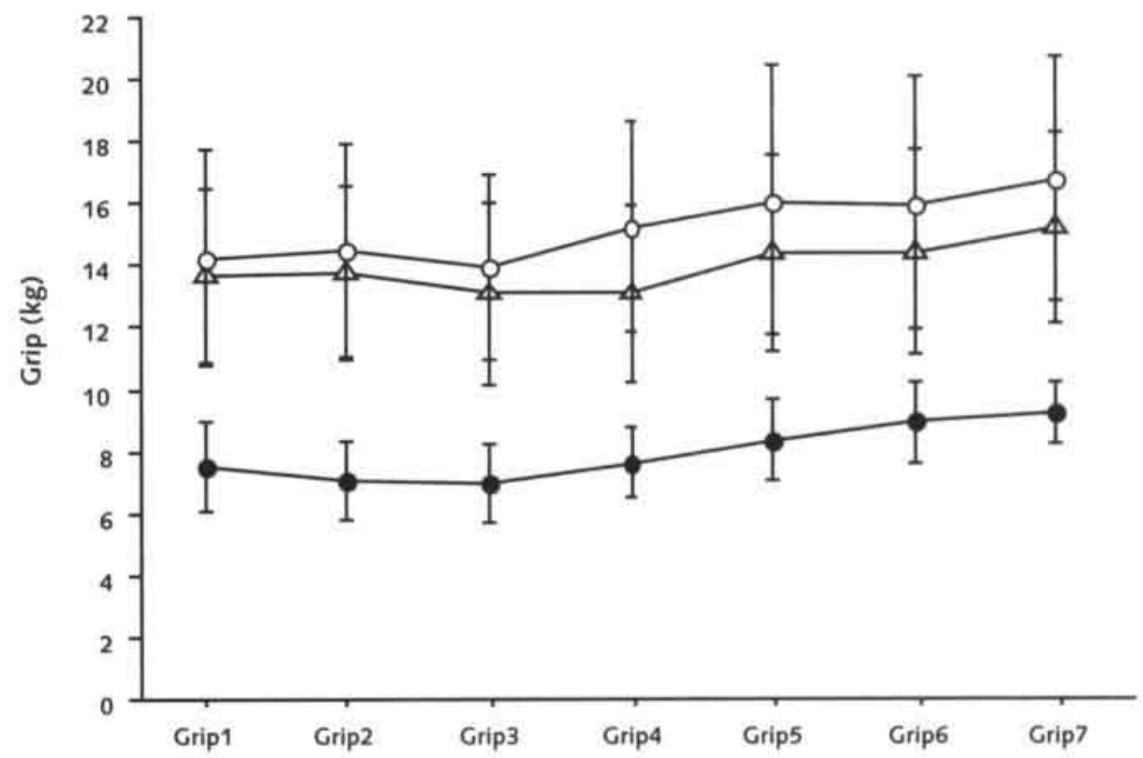


There is another reason to assume that height can only partly explain the increase in endurance time. Although the good responders had the same endurance time as the controls after one year of therapy, their height was still significantly lower.

The additional effect of $\mathrm{GH}$ can be accounted for by the metabolic effects of the hormone. Effects of $\mathrm{GH}$ on cardiac function have been described. In rats, the expression of the $\mathrm{GH}$ receptor gene was found to be stronger in the myocardium than in other tissues (16). GH also stimulates IGF-1 mRNA expression in the rat heart and skeletal muscle $(17,18)$. Furthermore, there is evidence of a stimulatory effect of IGF-1 on cultured cardiomyocyte growth (19). An additional explanation is the known increase in erythrocyte mass or oxygen transport capacity caused by a stimulatory effect of IGF-1 on erythropoiesis (20-23).

However, research in children found no association with changes in echocardiographic parameters of left ventricular size and function when these parameters were corrected for changes in body size (24-27). More research should be performed to see if changes in oxygen transport capacity lead to a better endurance time in children receiving $\mathrm{GH}$ therapy.

In the present study, grip strength was much lower in good responders than in controls and poor responders. This can probably be attributed to the difference in weight, while weight was in all groups a significant predictor for the grip strength. From the present data it cannot be concluded that there is an additional effect of $\mathrm{GH}$ on grip strength, because handgrip strength showed comparable increases in all groups. Also, there was no difference in the correlation between weight or TBW and Grip, suggesting that the most important cause of the increase in grip strength is the increase in weight and TBW caused by normal growth.

In muscle force generation, the maximum tension of a muscle is considered to be proportional to its cross-sectional area (28). However, it has been shown in acromegaly patients that an increase in muscle mass did not necessarily result in greater muscle strength (29). While $\mathrm{GH}$-induced muscle enlargement does occur in the absence of muscular work, it does not appear to increase the amount of contractile protein, thus producing no enhancement of muscular strength (30).

In a recent study ( $M$. Hoos, submitted for publication) we showed that the amount of time children with a good response to $\mathrm{GH}$ therapy spent on high intensity activities like running was increased by the therapy. This might cause a neurogenic training effect on the leg muscles, which would provide a possible explanation for the fact that an additional effect was seen on Tend of GH.

The present study measured endurance time and grip strength in young children, which implies some caveats. First, it would have been ideal to have measured oxygen consumption as a measure of physical fitness. This procedure, however, is difficult to perform in young children, and might have led to decreased compliance. Second, it is sometimes hard for children to demonstrate maximum performance. The control group was included to partly correct for this bias. All children were encouraged in the same way by the same investigator. 
In summary, the present study evaluated the effect of $\mathrm{GH}$ therapy on endurance time and grip strength in children receiving $\mathrm{GH}$ therapy for medical treatment. It was shown that endurance time had increased in children with a good response to GH therapy after one year of therapy. Although grip strength had also increased, this increase was not different from that which can be expected in age-matched children.

\section{ACKNOWLEDGEMENTS}

We would like to thank J.M.J. Sijstermans and P.M.V.M. Theunissen of the Atrium Hospital Heerlen for their contributions to this study. 


\section{REFERENCES}

1. Gregory JW, Greene SA, Jung RT, Scrimgeour CM, Rennie M. Changes in body composition and energy expenditure after six weeks' growth hormone treatment. Arch Dis Child 1991;66:598-602.

2. Vaisman N, Zadik Z, Akivias A, Voet H, Katz I, Yair S, Ashkenazi A. Changes in body composition, resting energy expenditure, and thermic effect of food in short children on growth hormone therapy. Metabolism 1994;43:1543-1548.

3. Rosen T, Bengtsson BA. Premature mortality due to cardiovascular disease in hypopituitarism. Lancet 1990;336:285-288.

4. Amato G, Carella C, Fazio S, La Montagna G, Cittadini A, Sabatini D, Marciano-Mone C, Sacca $\mathrm{L}$, Bellastella A. Body composition, bone metabolism, and heart structure and function in growth hormone (GH)-deficient adults before and after $\mathrm{GH}$ replacement therapy at low doses. I Clin Endocrinol Metab 1993;77:1671-1676.

5. Longobardi S, Cuocolo A, Merola B, Di Rella F, Colao A, Nicolai E, Cardei S, Salvatore M, Lombardi $G$. Left ventricular function in young adults with childhood and adulthood onset growth hormone deficiency. Clin Endocrinol (Oxf) 1998;48:137-143.

6. Colao A, di Somma C, Cuocolo A, Spinelli L. Tedesco N, Pivonello R, Bonaduce D, Salvatore M, Lombardi G. Improved cardiovascular risk factors and cardiac performance after 12 months of growth hormone $(\mathrm{GH})$ replacement in young adult patients with $\mathrm{GH}$ deficiency. J Clin Endocrinol Metab 2001;86:1874-1881.

7. Thuesen L, Jorgensen JO, Muller JR, Kristensen BO, Skakkebaek NE, VahI N, Christiansen JS. Short and long-term cardiovascular effects of growth hormone therapy in growth hormone deficient adults. Clin Endocrinol (Oxf) 1994;41:615-620.

8. Valcavi R, Gaddi O, Zini M, lavicoli M, Mellino U. Portioli I. Cardiac performance and mass in adults with hypopituitarism: effects of one year of growth hormone treatment. J Clin Endocrinol Metab 1995;80:659-666.

9. Jorgensen JO, VahI N, Hansen TB, Thuesen L. Hagen C, Christiansen JS. Growth hormone versus placebo treatment for one year in growth hormone deficient adults: increase in exercise capacity and normalization of body composition. Clin Endocrinol (Oxf) 1996:45:681-688.

10. Nass R, Huber RM, Klauss V, Muller OA, Schopohl J, Strasburger Cl. Effect of growth hormone $(\mathrm{hGH})$ replacement therapy on physical work capacity and cardiac and pulmonary function in patients with hGH deficiency acquired in adulthood. I Clin Endocrinol Metab 1995;80:552-557.

11. Gerver WJM, de Bruin R. Paediatric Morphometrics, A reference manual. (second extended edition) ed. Maastricht: Universitaire pers Maastricht, 2001.

12. Ranke $M B$, Guilbaud $O$. Growth response in prepubertal children with idiopathic growth hormone deficiency during the first two years of treatment with human growth hormone. Analysis of the Kabi Pharmacia International Growth Study. Acta Paediatr Scand Suppl 1991;379:109-115.

13. Bruce RA, Kusumi F, Hosmer D. Maximal oxygen intake and nomographic assessment of functional aerobic impairment in cardiovascular disease. Am Heart J 1973;85:546-562. 
14. Fomon SJ, Haschke F, Ziegler EE, Nelson SE. Body composition of reference children from birth to age 10 years. Am J Clin Nutr 1982;35:1169-1175.

15. Cuneo RC, Salomon F, Wiles CM, Hesp R, Sonksen PH. Growth hormone treatment in growth hormone-deficient adults. II. Effects on exercise performance. I Appl Physiol 1991;70:695-700.

16. Mathews LS, Enberg B, Norstedt G. Regulation of rat growth hormone receptor gene expression. J Biol Chem 1989;264:9905-9910.

17. D'Ercole A, Stiles AD, Underwood LE. Tissue concentrations of somatomedin C: further evidence for multiple sites of synthesis and paracrine or autocrine mechanisms of action. Proc Natl Acad Sci U S A 1984:81:935-939.

18. Isgaard J, Nilsson A, Vikman K, Isaksson OG. Growth hormone regulates the level of insulin-like growth factor-I mRNA in rat skeletal muscle. J Endocrinol 1989:120:107-112.

19. Ito H, Hiroe M, Hirata Y, Tsujino M, Adachi S, Shichiri M, Koike A, Nogami A, Marumo F. Insulinlike growth factor-I induces hypertrophy with enhanced expression of muscle specific genes in cultured rat cardiomyocytes. Circulation 1993;87:1715-1721.

20. Christ ER, Cummings MH, Westwood NB, Sawyer BM, Pearson TC, Sonksen PH, Russell-Jones $\mathrm{DL}$. The importance of growth hormone in the regulation of erythropoiesis, red cell mass, and plasma volume in adults with growth hormone deficiency. I Clin Endocrinol Metab $1997: 82: 2985-2990$.

21. Claustres $M$, Chatelain $P$, Sultan C. Insulin-like growth factor I stimulates human erythroid colony formation in vitro. J Clin Endocrinol Metab 1987;65:78-82.

22. Jepson JH, McGarry EE. Hemopoiesis in pituitary dwarfs treated with human growth hormone and testosterone. Blood 1972;39:229-248.

23. Merchav S, Tatarsky I, Hochberg Z. Enhancement of erythropoiesis in vitro by human growth hormone is mediated by insulin-like growth factor I. Br I Haematol 1988;70:267-271.

24. Rowland TW, Morris AH, Biggs DE, Reiter EO. Cardiac effects of growth hormone treatment for short stature in children. J Pediatr Endocrinol 1991:4:19-23.

25. Crepaz R, Pitscheider W, Radetti G, Paganini C, Gentili L, Morini G, Braito E, Mengarda G. Cardiovascular effects of high-dose growth hormone treatment in growth hormone-deficient children. Pediatr Cardiol 1995:16:223-227.

26. Barton JS, Cullen S, Hindmarsh PC, Brook CG, Preece MA. Growth hormone treatment in idiopathic short stature: a preliminary analysis of cardiovascular effects. Acta Paediatr Suppl 1992:383:35-38.

27. Daubeney PE, McCaughey ES, Chase C, Walker JM, Slavik Z, Betts PR, Webber SA. Cardiac effects of growth hormone in short normal children: results after four years of treatment. Arch Dis Child 1995;72:337-339.

28. Patel TJ, Lieber RL. Force transmission in skeletal muscle: from actomyosin to external tendons. Exerc Sport Sci Rev 1997;25:321-363.

29. Pickett JB, Layzer RB, Levin SR, Scheider V, Campbell M. Sumner A. Neuromuscular complications of acromegaly. Neurology 1975;25:638-645. 
30. Bell W, Davies JS, Evans WD, Scanlon MF. Strength and its relationship to changes in fat-free mass, total body potassium, total body water and IGF-1 in adults with growth hormone deficiency: effect of treatment with growth hormone. Ann Hum Biol 1999;26:63-78. 
Chapter 7

\section{SHORT-TERM EFFECTS OF GROWTH}

HORMONE ON BODY COMPOSITION

AS A PREDICTOR OF GROWTH

Marije B. Hoos ${ }^{1}$, Klaas R. Westerterp ${ }^{2}$ and Willem-Jan M. Gerver ${ }^{1}$

From the department of Pediatrics ${ }^{1}$, department of Human Biology ${ }^{2}$ University of Maastricht, the Netherlands

Journal of Clinical Endocrinology \& Metabolism 2003;88(6):2569-2572. 


\section{ABSTRACT}

The objective of this study was to investigate whether short-term changes in metabolism, as a result of growth hormone (GH) therapy, could be used to predict its growth effect after one year.

Twenty-eight children ( $8.7 \pm 2.8$ years) were selected, based on anthropometric criteria characterizing $\mathrm{GH}$ deficient patients. In addition, 21 healthy age- and sex-matched controls $(8.9 \pm 3.1$ years) were included. Total body water (TBW) and height were measured before and at six weeks and one year after the start of treatment. After one year of treatment, patients were divided into good and poor responders based on a change in height of at least 0.7 standard deviationscore (SDS).

Because individuals of different heights were compared, changes in TBW after six weeks were corrected for height ${ }^{2}$ in accordance with the Body Mass Index. Eighty percent of the children who showed a good response to $\mathrm{GH}$ therapy had a change in TBW divided by height ${ }^{2}$ exceeding the 2 SD reference line of the controls. In contrast, poor responders did not differ from controls. Maximum GH concentrations found during endocrine tests were not significantly different between good and poor responders.

Changes in body composition data, after six weeks, proved valuable in identifying good responders to $\mathrm{GH}$ therapy. 


\section{INTRODUCTION}

Growth hormone $(\mathrm{GH})$ therapy is prescribed to correct height deficits in children whose own $\mathrm{GH}$ secretion is insufficient. Although the diagnosis and prediction of the effect of $\mathrm{GH}$ therapy on growth cause few problems in severely $\mathrm{GH}$-deficient patients, difficulties arise with children suffering from partial growth hormone deficiency. The outcome of endocrine tests in these patients is not discriminative and does not adequately predict the effect of therapy on growth. In addition, height measurement over a period of one year is required for a reliable evaluation of the growth response. The drawbacks of daily injections and high therapy costs are further reasons to try and find other ways to improve diagnosis and prediction in the short term.

Besides its growth-promoting effect, $\mathrm{GH}$ also influences metabolism in adults (1-3) as well as in children(4-8), producing changes that have been found to be related to changes in height $(9,10)$.

In view of this, the present study investigated whether short-term changes in metabolism as a result of $\mathrm{GH}$ therapy, could be used to predict its growth effect after one year. Body composition changes were measured six weeks after the start of GH therapy in 28 children and 21 age-matched controls without therapy. The patients were included purely on anthropometrical indications, the outcome of the endocrine tests not being decisive to start therapy. Growth was evaluated through the first year of therapy, after which children were classified as good or poor responders to $\mathrm{GH}$ therapy. Our hypothesis was that changes in body composition exceeding those found in the control group would occur only in patients with a good response to $\mathrm{GH}$ therapy. 


\section{SUBJECTS AND METHODS}

\section{Subjects}

Eligibility for therapy was based solely on one or more of the anthropometric criteria characterizing $\mathrm{GH}$ deficient patients:

- height at the start of treatment less than -2.5 SDS;

- deviation from target height more than 1.3 SDS;

- deviation of growth in the year before treatment more than - 0.25 SDS.

Children were excluded if other reasons than those related to $\mathrm{GH}$ for growth retardation were present. Because it is known that girls with Turner syndrome show a growth response to $\mathrm{GH}$ therapy, they were included in the analysis. To minimize the influence of environmental factors, age and sex-matched healthy controls were selected from friends or relatives of the patients living in the same neighborhood. They were assumed to be healthy, normally growing children, based on anamnestic information from the parents. The controls were measured simultaneously with the patients, but did not receive GH therapy. Parents and children were informed about the nature of the study and written consent was obtained. The study was approved by the Ethical Committee of the University Hospital Maastricht.

Of the 30 children who started treatment, two were not included in the analysis. One child (and the corresponding control) was excluded because of recurrence of a pituitary tumor. Another child was excluded because of missing data. As a result, 28 children, with a mean age of $8.7( \pm 2.8$ ) years, suspected of being $\mathrm{GH}$-deficient, and 21 healthy age-matched controls ( $8.9 \pm 3.1$ years of age) were included in the study. Height SDS at start of the study was $-3.12( \pm 0.9)$ for the patient group and $-0.91( \pm 1.2)$ for the control group.

Of the 28 children suspected of being $\mathrm{GH}$-deficient, 21 had a height below -2.5 SDS, 25 deviated by more than 1.3 SDS from their target height and 10 children showed a deviating growth chart. All patients, including one late-presenting Turner patient aged 16 years, were prepubertal by physical examination. Two control patients were already pubertal.

\section{Study design}

All measurements were done by the same investigator (M.B. Hoos). Before treatment was started, three endocrine tests were performed in the patient group to measure maximum serum $\mathrm{GH}$ values. The patients received $0.7 \mathrm{mg}$ Humatrope $/ \mathrm{m}^{2} /$ day. Four girls with Turner syndrome received $1.3 \mathrm{mg}$ Humatrope $\% / \mathrm{m}^{2} /$ day, in accordance with Dutch treatment criteria.

Height and weight were measured at the start of therapy, at six weeks and then every three months, up to a total of one year. Height was expressed as standard deviation score (SDS). The difference in SDS over one year $\left(S_{D S} S_{\text {t1year }}-S_{\text {SDS }}\right.$ ) was used to divide the patient group into good and poor responders. A change in SDS more than 0.7 was considered to be a 
good response, based on the mean response to $\mathrm{GH}$ therapy found in the study by Ranke et al (11).

As a metabolic effect parameter, total body water (TBW) was measured with the deuterium dilution technique before and at six weeks and one year after the start of therapy. TBW was used instead of fat-free mass because the hydration level of the fat-free mass, which in adults is assumed to be $73 \%$, is age-dependent in children (12).

To interpret TBW in individuals who differed in height, the results were corrected for height (13-15) as TBW/height ${ }^{2}$.

\section{Height}

Height was measured using a stadiometer. After shoes and socks had been removed, body height was measured, exerting a gentle upward pressure on the mastoid processes, so that the child was fully extended (16). A weight of $0.5 \mathrm{~kg}$ was placed on the headboard in order to flatten the child's hair and enable the physician to keep the child in the correct upright position.

\section{Deuterium dilution method}

TBW was measured with the stable isotope of hydrogen, according to the Maastricht protocol (17). The water was labeled at the hydrogen atom. Before the dose was administered, a background sample was taken to determine the natural abundance of deuterium in the urine. The children drank the water in the evening before they went to bed. The next morning, a urine sample was taken after the first voiding. Total body water was calculated as follows:

$$
C_{1} \cdot V_{1}=C_{2} * V_{2}
$$

$C_{1}=$ concentration of the label in the ingested fluid

$V_{1}=$ volume of the dose

$C_{2}=$ concentration of the tracer in the sample

$\mathrm{V}_{2}=$ distribution volume in the body

Due to the exchange of the tracer with non-aqueous substances in the body, $V_{2}$ had to be divided by 1.04 to determine TBW (17).

\section{Endocrine tests}

\section{Arginine test}

The arginine test was performed in the morning after an overnight fast. Arginine hydrochloride $(0.5 \mathrm{~g} / \mathrm{kg})$ was infused for 30 minutes. Blood samples were taken to measure growth hormone levels at $-15,0,30,45,60,75,90$ and 120 minutes after the start of the infusion (18). 


\section{Clonidine test}

The clonidine test was performed in the morning after an overnight fast. After an oral dose of clonidine $\left(0.15 \mathrm{mg} / \mathrm{m}^{2}\right.$, max. $\left.0.15 \mathrm{mg}\right)$, blood samples were taken every 30 minutes for the next two hours to measure growth hormone levels (18)

\section{Sleeping test}

Because natural peaks of growth hormone secretion occur during the first hours of sleep, blood samples were taken every 10 minutes during the first two hours of sleep to measure growth hormone levels.

\section{Growth hormone analysis}

The AutoDELFIAhGH assay (Wallac, Inc., Turku, Finland) was used to establish growth hormone concentrations in serum $(C V=3.5 \%$, lower detection limit $=0.03 \mathrm{mU} / \mathrm{l})$.

\section{Calculations}

TBW data of the control group were plotted against height ${ }^{2}$ at the start of the study, at six weeks and at one year, to evaluate the relation between height ${ }^{2}$ and body composition. A reference line was constructed from the baseline data.

The intra-individual difference in body composition of the controls at the start of the study and at six weeks thereafter was used to estimate the limits of normality.

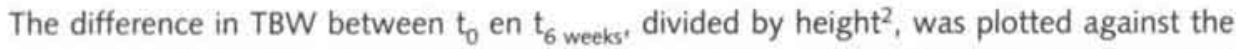
change in height SDS after one year of GH therapy (figure 7c). This graph was then used to calculate the sensitivity and specificity of the body composition measurement for the prediction of the effect of $\mathrm{GH}$ therapy on growth.

\section{RESULTS}

Patient characteristics are given in table 7a. Figure 7a shows the correlation between TBW and height ${ }^{2}$ for the control group at the start of the study $\left(\right.$ TBW $=3.5^{*}\left(\text { height }^{2}\right)^{2}-0.95^{*}$ height ${ }^{2}+6.83(\mathrm{Rsq}=0.97)$ ). The plotted data of the measurements taken at six weeks and one year were not significantly different from the data expected according to the reference line based on baseline data. A two-sample t-test found no significant difference in TBW/ height ${ }^{2}$ at the start of treatment between controls and poor responders, whereas good responders showed a significantly lower TBW/height ${ }^{2}$ at the start of treatment $(p<0.05)$.

In the control group, the mean difference in TBW between $t_{0}$ en $t_{6 \text { weeks }}$ divided by height ${ }^{2}$ was 0.39 , with a standard deviation (SD) of 0.27 . The use of two standard deviations resulted in an upper limit of $0.931 / \mathrm{m}^{2}$.

Figure $7 \mathrm{~b}$ shows the change in TBW over six weeks divided by height ${ }^{2}$. plotted against the change in height during one year (SDS) for all children. Two reference lines are shown. The 


\section{Figure 7a}

Relation between Total body water (TBW) and height ${ }^{2}$ for healthy children at start of study (o) after 6 weeks $(\bullet)$ and 1 year $(\triangle)$. Reference line is based on baseline data.

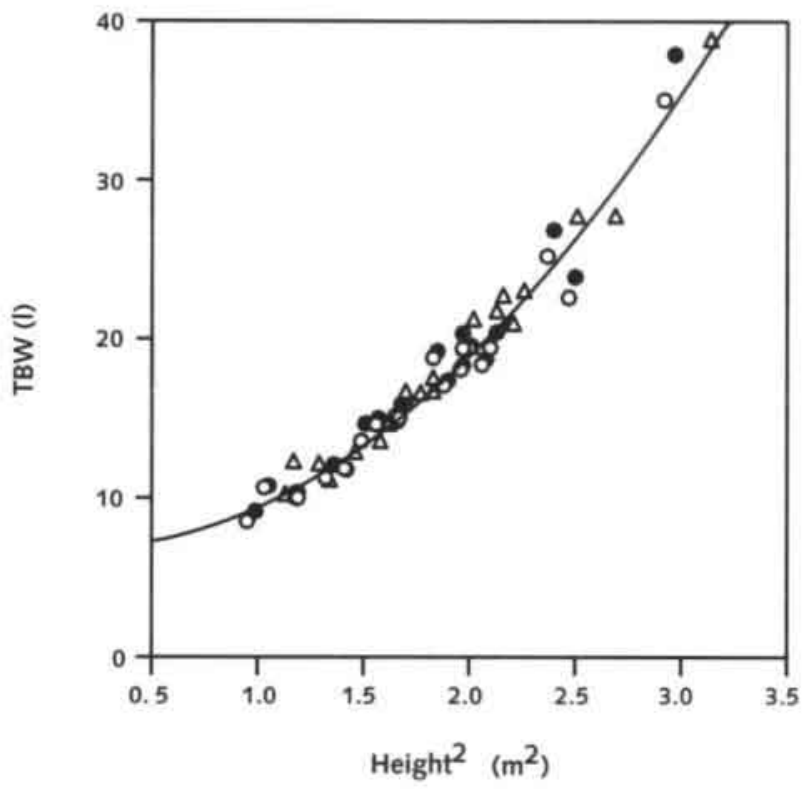

reference line on the $x$-axis represents a change in SDS $_{t+1}$ of 0.7 , which is the cut-off value chosen between good $(n=10)$ and poor responders $(n=18)$. The reference line on the $y$-axis indicates the mean change in TBW divided by height ${ }^{2}$ of the control group plus two times the standard deviation of this value $\left(0.93 \mathrm{l} / \mathrm{m}^{2}\right)$.

Eighty percent of the children who showed a good response to $\mathrm{GH}$ therapy had a change in TBW/height ${ }^{2}$ exceeding the 2 SD reference line of the control group. In contrast, the

Table 7a Subject characteristics.

\begin{tabular}{lrr}
\hline & $\begin{array}{c}\text { Controls } \\
n=21\end{array}$ & \multicolumn{1}{c}{$\begin{array}{c}\text { Patients } \\
n=28\end{array}$} \\
\hline Age (years) & $8.9( \pm 3.1)$ & $8.7( \pm 2.8)$ \\
Sex (M:F) & $(10: 11)$ & $(14: 14)$ \\
Height before therapy (SDS) & $-0.91( \pm 1.2)$ & $-3.12( \pm 0.9)$ \\
Height after 1 year of therapy (SDS) & $-0.86( \pm 1.2)$ & $-2.53( \pm 0.8)$ \\
Weight before therapy (kg) & $27.9( \pm 10.0)$ & $21.7( \pm 9.4)$ \\
Weight after 1 year of therapy (kg) & $31.3( \pm 11.2)$ & $25.0( \pm 9.9)$ \\
\hline
\end{tabular}

(values are means \pm standard deviation. M:male; F: female) 


\section{Figure $7 b$}

Change in TBW over 6 weeks divided by height ${ }^{2}$, plotted against change in SDS after 1 year for healthy controls $(\Delta)$ good responders $(\bullet)$ and poor responders (o).

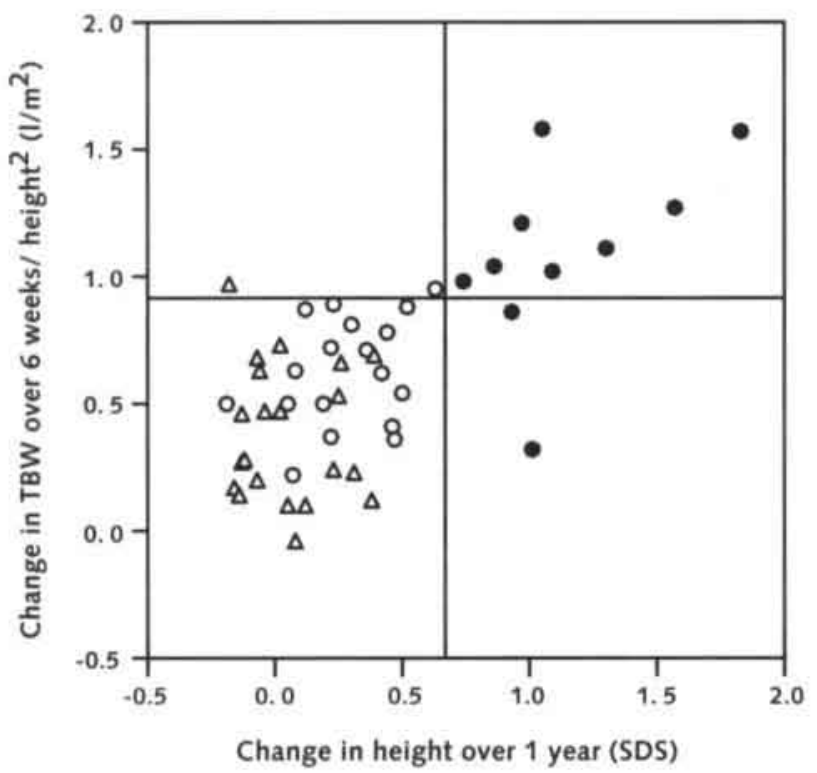

poor responders did not differ from the control group. The good responders showed a significantly higher change in TBW/height ${ }^{2}$ than the poor responders as tested by an unpaired t-test $(p<0.01)$. Based on the chosen cut-off values, the specificity of TBW change/height ${ }^{2}$ was $88 \%$ and the sensitivity $89 \%$. The Turner patients were all in the nonresponding quadrant and did not deviate from controls and poor responders.

Good responders were indistinguishable from poor responders with regard to the outcome of the endocrine tests (figure $7 \mathrm{c}$ ). Figure $7 \mathrm{c}$ shows the maximum $\mathrm{GH}$ concentrations found during the three endocrine tests before the start of therapy. The reference line on the $x$-axis indicates the difference between good and poor responders. A second reference line, on the $y$-axis, indicates a growth hormone concentration of $20 \mathrm{mU} / \mathrm{l}$. This value is usually taken as the maximum value found in GHD children.

The good responders had the following mean maximum values on the three endocrine tests: $20.8( \pm 7.4) \mathrm{mU} / \mathrm{l}$ for the arginine test, $36.3( \pm 27.9) \mathrm{mU} / \mathrm{I}$ for the clonidine test and $14.8( \pm 11.1) \mathrm{mU} / \mathrm{l}$ for the sleep test. Mean values for the poor responders were 21.7 $( \pm 10.9), 35.5( \pm 29.8)$ and $19.8( \pm 9.9) \mathrm{mU} / \mathrm{l}$ respectively. These values were not statistically different according to an unpaired t-test.

The percentage of patients whose response was correctly predicted by their height at the start of treatment was $57 \%$. This means that the patients who were smaller than -2.5 SDS 
and responded well to $\mathrm{GH}$ therapy, together with the patients who were taller than 2.5 SDS and did not respond to $\mathrm{GH}$, constituted $57 \%$ of all patients. The percentage of patients whose response was correctly predicted by their deviation from the target height was $50 \%$. The corresponding value for the change in height in the year before therapy was $79 \%$. The change in TBW over six weeks divided by height ${ }^{2}$ correctly predicted the response of $89 \%$ of the patients.

\section{DISCUSSION}

The present study evaluated the use of changes in body composition for the prediction of the effect of $\mathrm{GH}$ therapy. Most children who responded well to $\mathrm{GH}$ therapy showed an evident increase in TBW/height ${ }^{2}$, while the poor responders were indistinguishable from controls. Total body water was measured as a function of height, in accordance with the Body Mass Index (weight/height ${ }^{2}$ ), because children of different heights were compared. This correction was justified by the strong correlation between TBW and height ${ }^{2}$ found in the control group.

Two limits of normality were assumed. The upper limit for the change in TBW over six weeks divided by height ${ }^{2}$ was established by taking the mean change in the control group plus two times the standard deviation $\left(0.93 \mathrm{l} / \mathrm{m}^{2}\right)$.

\section{Figure 7c}

Growth hormone concentrations found by the clonidine test $(\bullet)$ sleep test $(0)$ and arginine test $(\triangle)$, plotted against change in SDS after one year.

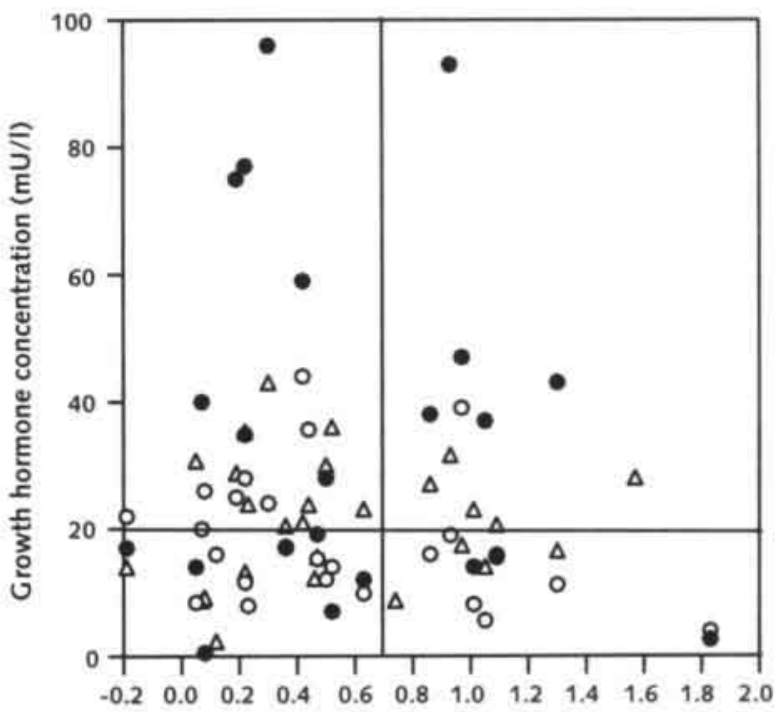

Change in height over 1 year (SDS) 
Because we applied age and sex matching, the two eldest prepubertal patients were matched with already pubertal controls. However, we assumed that puberty has no detectable effect on body composition within a period of six weeks.

Based on their response to $\mathrm{GH}$ therapy after one year, patients were divided into good and poor responders (change in height above or below 0.7 SDS). Applying these two limits of normality (0.7 SDS on the $x$-axis and $0.93 \mathrm{l} / \mathrm{m}^{2}$ on the $y$-axis) leads to four quadrants when the change in SDS over one year is plotted against the change in TBW divided by height ${ }^{2}$. As expected, all controls are situated in the lower left quadrant. The poor responders are also found in this quadrant, meaning that no distinction can be made between controls and poor responders. By contrast, 8 of the 10 good responders are in the upper right quadrant. This graph thus shows sensitivity and specificity to be high ( $88 \%$ and $89 \%$, respectively). indicating that the use of changes in body composition is a reliable tool for the diagnosis of GHD.

Patient selection in the present study was only based on anthropometric arguments and not on endocrine testing, to prevent any bias from false-positive or false-negative biochemical results. The present study could only be performed by including children with idiopathic short stature, because of the need to include the whole range of expected responses to GH therapy, poor as well as good. Parents were fully informed in advance of the possibility that the therapy could have a disappointing effect. If after one year, the therapy did not prove to be successful, the treatment was stopped. The endocrine tests that were nevertheless performed showed that most children had two endocrine test results less than $20 \mathrm{mU} / \mathrm{I}$ (Figure 7c), but a third test above $20 \mathrm{mU} / \mathrm{I}$. Plotted against the change in height after one year, the results of the endocrine tests were randomly distributed. If the start of $\mathrm{GH}$ treatment had been dependent on these endocrine tests, meaning that all measured $\mathrm{GH}$ values had to be less than $20 \mathrm{mU} / \mathrm{l}$, one good and one poor responder would have been treated.

In our group of patients, therefore, the use of endocrine tests did not lead to an accurate prediction of the response to $\mathrm{GH}$ therapy, corroborating the conclusions of other reports in the literature, which have questioned the reliability of endocrine tests. (19-24). By contrast, the change in height in the year before therapy was found to predict the response of $79 \%$ of the patients correctly, which comes close to the percentage of children whose response was predicted correctly on the basis of the change in TBW over six weeks divided by height ${ }^{2}$, i.e., $89 \%$.

In conclusion, changes in body composition data proved to be valuable for the distinction between good and poor responders to $\mathrm{GH}$ therapy. However, it should be realized that the cut-off values used for growth response as well as change in body composition are more or less arbitrary.

\section{ACKNOWLEDGEMENTS}

We would like to thank J.M.J. Sijstermans and P.M.V.M. Theunissen of the Atrium hospital Heerlen for their contributions to this study. 


\section{REFERENCES}

1. Beshyah SA, Freemantle C, Thomas E, Rutherford O, Page B, Murphy M, Johnston DC. Abnormal body composition and reduced bone mass in growth hormone deficient hypopituitary adults. Clin Endocrinol (Oxf) 1995:42:179-189.

2. Christiansen JS, Jorgensen JO, Pedersen SA, Moller J, Jorgensen J, Skakkeboek NE. Effects of growth hormone on body composition in adults. Horm Res 1990:33 Suppl 4:61-64.

3. Lucidi P, Laureti S, Santoni S, Lauteri M, Busciantella-Ricci N, Angeletti G, Santeusanio F, De Feo $P$. Administration of recombinant human growth hormone on alternate days is sufficient to increase whole body protein synthesis and lipolysis in growth hormone deficient adults. Clin Endocrinol (Oxf) 2000:52:173-179.

4. Boot AM, Engels MA, Boerma GJ, Krenning EP, De Muinck Keizer-Schrama SM. Changes in bone mineral density, body composition, and lipid metabolism during growth hormone (GH) treatment in children with $\mathrm{GH}$ deficiency. I Clin Endocrinol Metab 1997;82:2423-2428.

5. Cowan FJ, Evans WD, Gregory JW. Metabolic effects of discontinuing growth hormone treatment. Arch Dis Child 1999;80:517-523.

6. Hassan $\mathrm{HM}$, Kohno $\mathrm{H}$, Kuromaru R, Honda S, Ueda K. Body composition, atherogenic risk factors and apolipoproteins following growth hormone treatment. Acta Paediatr 1996;85:899-901.

7. Vaisman N, Zadik Z, Akivias A, Voet H, Katz I, Yair S, Ashkenazi A. Changes in body composition, resting energy expenditure, and thermic effect of food in short children on growth hormone therapy. Metabolism 1994;43:1543-1548.

8. Vaisman N, Zadik Z, Shamai Y, Franklin L, Dukhan R. Changes in body composition of patients with subnormal spontaneous secretion of growth hormone, during the first year of treatment with growth hormone. Metabolism 1992:41:483-486.

9. Gregory JW, Greene SA, Jung RT, Scrimgeour CM, Rennie MJ. Metabolic effects of growth hormone treatment: an early predictor of growth response? Arch Dis Child 1993;68:205-209.

10. Gerver WJ, De Bruin R, Delemarre v d Waal HA, Aldewereld B, Theunissen P, Westerterp KR. Effects of discontinuation of growth hormone treatment on body composition and metabolism. Horm Res 2000;53:215-220.

11. Ranke $M B$, Guilbaud $O$. Growth response in prepubertal children with idiopathic growth hormone deficiency during the first two years of treatment with human growth hormone, Analysis of the Kabi Pharmacia International Growth Study. Acta Paediatr Scand Suppl 1991;379:109-115.

12. Fomon SJ, Haschke F, Ziegler EE, Nelson SE. Body composition of reference children from birth to age 10 years. Am J Clin Nutr 1982;35:1169-1175.

13. Vanltallie TB, Yang MU, Heymsfield SB, Funk RC, Boileau RA. Height-normalized indices of the body's fat-free mass and fat mass: potentially useful indicators of nutritional status. Am I Clin Nutr 1990;52:953-959.

14. Wells JC. A critique of the expression of paediatric body composition data. Arch Dis Child 2001;85:67-72. 
15. Wells JC, Cole TJ. Adjustment of fat-free mass and fat mass for height in children aged $8 \mathrm{y}$. Int J Obes 2002:26:947-952.

16. Gerver WIM, de Bruin R. Paediatric Morphometrics, A reference manual. (second extended edition) ed. Maastricht: Universitaire pers Maastricht, 2001.

17. Westerterp KR, Wouters L, Van Marken-Lichtenbelt W. The Maastricht protocol for the measurement of body composition and energy expenditure with labeled water. Obes Res 1995;3:49-57.

18. De Muinck Keizer-Schrama SMPF, Boukes FS, Oostdijk W, Rikken B. Diagnostiek kleine lichaamslengte bij kinderen [Diagnosis of short stature in children]. Alphen aan de Rijn: van Zuiden Commmunications B.V., 1998.

19. Andersson AM, Orskov H, Ranke MB, Shalet S, Skakkebaek NE. Interpretation of growth hormone provocative tests: comparison of cut-off values in four European laboratories. Eur $J$ Endocrinol 1995; 132:340-343.

20. Ghigo E, Bellone J. Aimaretti G, Bellone S, Loche S, Cappa M, Bartolotta E, Dammacco F, Camanni F. Reliability of provocative tests to assess growth hormone secretory status. Study in 472 normally growing children. J Clin Endocrinol \& Metab 1996;81:3323-3327.

21. Lin T-H, Kirkland RT, Sherman BM, Kirkland J. Growth hormone testing in short children and their response to growth hormone therapy. I Pediatr 1989:115:57-63.

22. Preece MA. Making a rational diagnosis of growth-hormone deficiency. f Pediatr 1997;131:56164.

23. Rosenfeld RG, Albertsson-Wikland K, Cassorla F, Frasier SD, Hasegawa Y, Hintz RL, Lafranchi S, Lippe B, Loriaux L, Melmed S, Preece MA, Ranke MB, Reiter EO, Rogol AD, Underwood LE, Werther GA. Diagnostic controversy: the diagnosis of childhood growth hormone deficiency revisited. I Clin Endocrinol Metab 1995;80:1532-1540.

24. Van den Broeck J, Hering P, Van de Lely A, Hokken-Koelega A. Interpretative difficulties with growth hormone provocative retesting in childhood-onset growth hormone deficiency. Horm Res 1999:51:1-9. 
CHAPTER 8

DISCUSSION 
98 | 


\section{DISCUSSION}

Although recombinant growth hormone $(\mathrm{GH})$ has been prescribed in $\mathrm{GH}$-deficient patients since 1985, it is still problematic to define the patients who will benefit from it. As the current tests appear to be insufficient to predict the growth effect of growth hormone, a better method is needed. The basic aim of the research reported on in this thesis was to find an instrument that is able to predict the long-term effect of $\mathrm{GH}$ on growth by measuring its short-term effect on physical activity and body composition.

There are several reasons why a good diagnostic tool to distinguish between good and poor responders to $\mathrm{GH}$ therapy is needed. The most important reason is of course the proper treatment of the patient, in terms of preventing unnecessary initiation of therapy as well as interruption of the therapy as soon as it proves ineffective. However, $\mathrm{GH}$ therapy needs to be sustained for at least six, but preferably twelve months before its anthropometric effectiveness can be evaluated.

Current endocrine tests are not only poor predictors of the effect of GH therapy, especially in partially $\mathrm{GH}$-deficient patients, they are also unpleasant for children, because the drugs which are used to provoke a $\mathrm{GH}$ response can have uncomfortable side effects.

High costs are another important factor creating a need for a better diagnostic tool. The implementation of endocrine tests is expensive because it requires hospitalisation. In addition, every test involves the analysis in the laboratory of many blood samples. However, these are relatively insignificant compared to the costs of $\mathrm{GH}$ therapy itself, which are about $€ 17,700$ per patient per year, assuming a mean dosage of $1 \mathrm{mg}$ per day. Because of these high costs, the Dutch government has centralized the prescription of $\mathrm{GH}$.

Based on the above-mentioned arguments it is of paramount importance that no subjects should be treated without reliable prospects of enhanced growth. This would require high test specificity, but high specificity usually implies that some subjects may not be treated, even though they might have responded to therapy. On the other hand, including all subjects who will respond to therapy would require a high sensitivity, but this implies that some children who will not respond to GH therapy are also treated. It is therefore necessary to decide which of the two aspects should predominate: treating all children that respond to therapy or minimizing the negative aspects of treatment (the physical inconvenience of daily injections, disappointment after high expectations of increased height, and high costs).

The increasing numbers of parents and/or children presenting at the pediatrician with problems of negative self-esteem because of short stature indicates the importance of growth problems at the pediatric outpatient clinic. Height seems extremely important, as being tall seems to be associated with higher income, self-esteem and social status $(1,2)$. It is probably for this reason that parents are concerned when their child seems to have growth problems. There is, however, no consensus about the negative physiologic effects of short stature. It is believed that children with short stature, and especially children with extremely short stature, will experience a range of problems in their daily lives. Although 
studies report that about $50-75 \%$ of short children are treated as if they were younger than their actual age and are teased about their short stature $(3,4)$, most children generally present as psychologically well adapted (2). By contrast, Stabler (5) concluded that many children who are referred to paediatric endocrinologists have behavioral problems, some of which ameliorate during treatment with $\mathrm{GH}$. However, this effect may have been enhanced by the study design, in that children with concurrent behavioral problems may be more likely to be referred to the pediatric endocrinologists.

A key issue in the present study was to make a distinction between good and poor responders to $\mathrm{GH}$ therapy. A change in height SDS after one year of 0.7 was taken as the cut-off point, being the mean value found in a study by Ranke et al. (6), but also in an analysis of growth data by the Dutch Growth Foundation (personal communication). Although it is often claimed that all children tend to show a response during the first year of $\mathrm{GH}$ therapy, this could not be confirmed in the present study, as there were children who showed no change in height SDS in the first year of therapy. In addition, we assume that a change of 0.7 height SDS is sufficient to identify these children as responders to GH therapy.

Besides the influence on height, the effects of $\mathrm{GH}$ on metabolism are worth considering and an important additional aspect for the patient. Children with Prader Willi syndrome, for example, present with diminished growth, reduced lean body mass, obesity, hypotonia and behavioral abnormalities. Apart from the increase in height, $\mathrm{GH}$ therapy in these children causes an increase in lean body mass, physical strength and agility $(7,8)$ as well as behavioral changes ( 8 ). This reduces some of the physical disabilities experienced by these children, which might be just as important as, or even more important than, the height increase. Awareness of this effect, not only in Prader Willy patients but also in other groups (9-12), has led to the idea to use the metabolic consequences as predictors of the effect of $\mathrm{GH}$ therapy on growth.

Metabolism can be translated into physical activity. However, before deviating levels of physical activity in children receiving GH therapy could be established, normal values of physical activity needed to be determined in healthy children. Chapter two shows that physical activity levels (PAL) and activity related energy expenditure (AEE) increase with age. This relation was not found when AEE was expressed per kg weight, indicating that the increase in weight by age is probably a reason for the increase in PAL and AEE.

In addition to physical activity levels, accelerometry can be used to measure physical activity patterns, assessing the percentage of time spent on activities of low- (sitting), moderate(walking) and high-intensity (running) activities. Although the Tracmor 2 device has been shown to be a reliable instrument for the measurement of physical activity in adults (13), it had not been used in children before, so we first validated it against data obtained using the doubly labeled water (DLW) method. The high correlation $(r=0.79)$ found between Tracmor output and DLW data demonstrated that the Tracmor2 is a reliable tool to measure physical activity in children (chapter 3 ). 
PAL values proved to be inversely related to the time spent on low-intensity activities and directly related to the time spent on high-intensity activities in healthy, normally growing children (chapter 4). This finding contrasted with findings in adults, whose physical activity levels proved to be effectively increased by an increase in moderate-intensity activities (14) probably because high-intensity activities are usually not sustained for long periods of time.

The specific activity patterns among children, which are characterized by short, intermittent bouts of vigorous physical activity (15-18) were also reflected in the time children spent on high-intensity activities. Children were found to spend more time on-high intensity activities than adults, probably because their lower weight makes it easier for them to perform high-intensity activities. However, even though children spent more time on highintensity activities, accelerometry revealed lower PAL values. Apart from the fact that it takes children less energy to perform high-intensity activities because of their lower weight, these low PAL values can probably be attributed to shorter total physical activity times, as children sleep more than adults.

When comparing the activity patterns of $\mathrm{GH}$-treated children with those of healthy, normally growing controls (chapter 5), good responders to $\mathrm{GH}$ therapy were found to spend less time on high-intensity activities before the start of treatment. After two weeks of GH therapy, however, this difference had disappeared. Possible reasons for the decreased level of physical activity might be impaired erythropoiesis and decreased plasma and total blood volumes (19), factors that influence physical performance capacity (20). In GHdeficient adults, such impaired erythropoiesis and decreased plasma and total blood volumes have been proven to ameliorate during $\mathrm{GH}$ treatment $(19,21)$. Moller et al. proved that plasma volume increases after as little as three weeks (22).

Poor responders to $\mathrm{GH}$ therapy did not differ from controls, and two weeks of therapy did not influence their activity levels. $\mathrm{GH}$ probably had no effect on activity because the growth retardation in this patient group was not based on $\mathrm{GH}$ deficiency. Endurance time, which was measured before and during the first year of therapy, was not influenced by $\mathrm{GH}$ therapy in this patient group either.

In the good responders, however, there was a significant increase in the length of time for which the children were able to perform an endurance test on a treadmill. In addition to the effects on erythropoiesis and blood volume, this improved endurance time was probably caused by an increase in height (chapter 6 ).

Unfortunately, although changes in physical activity were measurable after a short period of time in the good responders group, they were not predictive of the effect of GH therapy on growth. The change in body composition as a result of $\mathrm{GH}$ administration proved to be a more promising metabolic predictor of the growth effect. In adults, the under water weighing (UWW) method is regarded as the "gold standard" for measuring body composition. Applying this method to young children, however, is not without problems. The UWW method is based on the measurement of body volume, and this body volume as measured by UWW has to be corrected for lung volume, ideally by simultaneously measuring the residual lung volume during submersion (23). This means that children have 
to be submersed in water with a mouthpiece in their mouth, which connects them to the lung volume meter. This is technically difficult and frightening for young children, rendering accurate measurements impossible. A problem in the measurement of body composition in children is the need for age-dependent constants for the hydration of the fat-free mass (24, 25) since hydration of the fat-free mass changes with age. The under water weighing method also depends on assumptions about a constant hydration of the fat-free mass. Another disadvantage of the use of UWW is that most centres lack the equipment for this method.

In the present study, body composition was measured using the deuterium dilution technique, which is a good instrument to measure body composition in children (26). The method is non-invasive and easily applicable, even in infants, because only small urine samples are needed, which can be easily collected by placing cotton wools in the diaper. The deuterium dilution method is based on the measurement of total body water (TBW). To calculate the percentage of fat-free mass, TBW needs to be corrected for the hydration of the fat free mass. This hydration factor is assumed to be $73 \%$ for adults, but this constant factor cannot be used in children $(25,27)$. To exclude possible confounding by the hydration of the fat-free mass, the present study used the actual total body water data.

The change in TBW/height ${ }^{2}$ was found to be a useful parameter to predict the effect of GH therapy on growth (chapter 7). This method was capable of distinguishing between good and poor responders, after as little as six weeks of treatment. Only two of the ten patients who did respond to $\mathrm{GH}$ therapy did not show an increase in TBW/height ${ }^{2}$ differing from controls. The time between the collection of the second urine sample and the ingestion of the deuterium in these two patients may have been too long in the measurement before the start of $\mathrm{GH}$ therapy. This causes an overestimation of the total body water and a smaller difference after six weeks of therapy. A disadvantage of the deuterium method is that it sometimes takes a long time before children are able to pass water so that a urine sample can be collected. If this method is really to be used as the only diagnostic criterion for GHD, the method should perhaps be performed in duplicate before as well as after therapy. Because the method is non-invasive and relatively cheap, this would be the best way to increase sensitivity and specificity.

Unlike all other models, this method can predict the $\mathrm{GH}$ response after as little as six weeks of $\mathrm{GH}$ treatment, using only one effect parameter. Although we assessed a relatively small number of patients, results for this small sample were very clear, indicating that it would be useful to confirm the results in a larger sample. If this predictive model proves to be highly specific for a large cohort as well, a trial period of six weeks can be recommended to select those children who will benefit from the use of $\mathrm{GH}$. This would mean that disappointment after one year of ineffective therapy is avoided, as well as the physical discomfort of daily injections over such a long period. In addition, the cost aspect is also important, as the cost of one year of therapy would cover a six-week trial therapy for nine children. 


\section{REFERENCES}

1. Bolt LL, Mul D. Growth hormone in short children: beyond medicine? Acta Paediatr 2001;90:69-73.

2. Kelnar Cl, Albertsson-Wikland K, Hintz RL, Ranke MB, Rosenfeld RG. Should we treat children with idiopathic short stature? Horm Res 1999:52:150-157.

3. Zimet GD, Cutler M, Litvene M, Dahms W, Owens R, Cuttler L. Psychological adjustment of children evaluated for short stature: a preliminary report. I Dev Behav Pediatr 1995:16:264-270.

4. Sandberg DE, Brook AE, Campos SP. Short stature; a psychosocial burden requiring growth hormone therapy? Pediatrics 1994:94:832-840.

5. Stabler B, Siegel PT, Clopper RR, Stoppani CE, Compton PG, Underwood LE. Behavior change after growth hormone treatment of children with short stature. J Pediatr 1998;133:366-373.

6. Ranke MB, Guilbaud $O$. Growth response in prepubertal children with idiopathic growth hormone deficiency during the first two years of treatment with human growth hormone. Analysis of the Kabi Pharmacia International Growth Study. Acta Paediatr Scand Suppl 1991;379:109-115.

7. Carrel AL, Myers SE, Whitman BY, Allen DB. Sustained benefits of growth hormone on body composition, fat utilization, physical strength and agility, and growth in Prader-Willi syndrome are dose-dependent. I Pediatr Endocrinol Metab 2001;14:1097-1105.

8. Lindgren AC, Hagenas L, Muller J, Blichfeldt S, Rosenborg M, Brismar T, Ritzen EM. Effects of growth hormone treatment on growth and body composition in Prader-Willi syndrome: a preliminary report. The Swedish National Growth Hormone Advisory Group. Acta Paediatr Suppl 1997:423:60-62.

9. Gregory JW, Greene SA, Jung RT, Scrimgeour CM, Rennie MJ. Changes in body composition and energy expenditure after six weeks' growth hormone treatment. Arch Dis Child 1991:66:598-602.

10. Vaisman N, Zadik Z, Akivias A, Voet H, Katz I, Yair S. Ashkenazi A. Changes in body composition, resting energy expenditure, and thermic effect of food in short children on growth hormone therapy. Metabolism 1994:43:1543-1548.

11. Stenlof K, Sjostrom L, Lonn L, Bosaeus I, Kvist H, Tolli J, Lindstedt G, Bengtsson BA. Effects of recombinant human growth hormone on basal metabolic rate in adults with pituitary deficiency. Metabolism 1995:44:67-74.

12. Snel YE, Doerga ME, Brummer RJ, Zelissen PM, Zonderland ML, Koppeschaar HP. Resting metabolic rate, body composition and related hormonal parameters in growth hormone-deficient adults before and after growth hormone replacement therapy. Eur J Endocrinol 1995;133:445450.

13. Bouten CV, Verboeket-van de Venne WP, Westerterp KR, Verduin M, Janssen JD. Daily physical activity assessment: comparison between movement registration and doubly labeled water. I Appl Physiol 1996;81:1019-1026.

14. Westerterp K. Pattern and intensity of physical activity. Nature 2001;410:539.

15. Rowland TW. The biological basis of physical activity. Med Sci Sports Exerc 1998;30:392-399. 
16. Bailey RC, Olson J, Pepper SL, Porszasz J, Barstow TJ, Cooper DM. The level and tempo of children's physical activities: an observational study. Med Sci Sports Exerc 1995;27:1033-1041.

17. Molnar D, Livingstone B. Physical activity in relation to overweight and obesity in children and adolescents. Eur I Pediatr 2000;159 Suppl 1:S45-55.

18. Council for physical education for children. Physical activity for children: a statement of guidelines. Reston: VA: NASPE Publications, 1998.

19. Christ ER, Cummings MH, Westwood NB, Sawyer BM, Pearson TC, Sonksen PH, Russell-Jones $\mathrm{DL}$. The importance of growth hormone in the regulation of erythropoiesis, red cell mass, and plasma volume in adults with growth hormone deficiency. I Clin Endocrinol Metab 1997;82:2985-2990.

20. Sawka MN, Convertino VA, Eichner ER, Schnieder SM, Young AJ. Blood volume: importance and adaptations to exercise training, environmental stresses, and trauma/sickness. Med Sci Sports Exerc 2000;32:332-348.

21. Vihervuori E, Virtanen M, Koistinen $H$, Koistinen R, Seppala M, Siimes MA. Hemoglobin level is linked to growth hormone-dependent proteins in short children. Blood 1996;87:2075-2081.

22. Moller J, Frandsen E, Fisker S, Jorgensen JO, Christiansen JS. Decreased plasma and extracellular volume in growth hormone deficient adults and the acute and proionged effects of GH administration: a controlled experimental study. Clin Endocrinol (Oxf) 1996;44:533-539.

23. Westerterp-Plantenga MS, Fredrix EWHM, Steffens AB. Food intake and energy expenditure. Heerlen: CRC Press, 1994.

24. Hewitt MJ, Going SB, Williams DP, Lohman TC. Hydration of the fat-free body mass in children and adults: implications for body composition assessment. Am J Physiol 1993:265:E88-95.

25. Reilly JJ. Assessment of body composition in infants and children. Nutrition 1998;14:821-825.

26. de Bruin NC, Westerterp KR, Degenhart HJ, Visser HK. Measurement of fat-free mass in infants. Pediatr Res 1995:38:411-417.

27. Fomon SJ, Haschke F, Ziegler EE, Nelson SE. Body composition of reference children from birth to age 10 years. Am J Clin Nutr 1982;35:1169-1175. 


\section{SUMMARY}

Doctors are frequently confronted with children suspected of having a growth disorder. The following criteria are used to assess whether they are really suffering from such a disorder:

- the child's height is more than 2.5 standard deviations below the average height of the reference population to which the child belongs;

- the child's height is more than 1.3 standard deviations below the expected height based on the parents' height (target height);

- a decrease in height of more than 0.25 standard deviations over one year.

If the child's growth meets one of these criteria, it is examined to detect any underlying pathology. One of the possible causes is growth hormone (GH) deficiency. The main test to establish such a deficiency is a growth hormone stimulation test, which in normal persons shows an increase in serum growth hormone concentrations exceeding $20 \mathrm{mU} / \mathrm{l}$. If two separate tests result in an increase below this value, the child is basically eligible for hormone therapy. However, the diagnostic value of these growth hormone tests has been seriously criticized.

Since growth hormone is excreted in pulses, a serum concentration in one single sample is unable to establish reduced secretion, which is why growth hormone stimulation tests are used. The outcome of such tests, however, is subject to major intra- and inter-individual variations depending on the agent used to stimulate hormone production. In addition, tests implemented at different laboratories should be harmonized to exclude differences at analytical level.

As with all medical interventions, the best proof of an effect is outcome. However, a reliable anthropometric assessment of the effect of growth hormone therapy can only be made after at least 6, but preferably 12 months, of treatment. And since growth hormone treatment involves daily injection and is a costly form of treatment, it would be valuable to be able to assess its effectiveness sooner.

In addition to its effect on growth, growth hormone also affects metabolism, an effect that starts shortly after the treatment is initiated. The present study was undertaken to evaluate whether changes in metabolism, expressed as energy expenditure and body composition, could be used to predict the effects of growth hormone on growth.

The main component of the total daily energy expenditure (TDEE) is the energy needed to maintain all vital body functions, the basal metabolic rate. The amount of energy invested in physical activity is the most variable component of the TDEE. The gold standard to measure TDEE is the doubly labeled water method. When the basal metabolic rate is measured in addition to TDEE, the amount of energy invested in physical activities, expressed as PAL (physical activity level) and AEE (activity related energy expenditure) can be established. 
An attempt was made to establish normal values for the relation between activity levels and age by analyzing the results of 17 studies using doubly labeled water. The amount of energy invested in physical activities, expressed as PAL and AEE was found to rise with age. Since no relation was found between age and the ratio of AEE to body weight, the rise in the amount of energy spent on physical activities is probably caused by the rise in body weight.

The children's activity patterns were measured with the help of the Tracmor2. The Tracmor2 is an accelerometer, which records the occurrence and intensity of movements. Activities were categorized as low-intensity (sitting), moderate-intensity (walking) or high-intensity (running). The study showed that children spent a larger percentage of their time on highintensity activities, as their lower body weight means such activities require less energy expenditure from them than from adults. PAL values were found to be related to the percentage of time spent on low- and high-intensity activities.

Activity patterns of children with normal growth were compared with those of children undergoing a growth hormone therapy. After a year of growth hormone therapy, the patients were subdivided into good responders (change in height $>0.7$ standard deviation score (SDS)) and poor responders (change in height $<0.7$ SDS). Before the start of the growth hormone therapy, good responders spent a smaller percentage of their active time on high-intensity activities than controls with a normal growth. This difference had disappeared after two weeks of growth hormone therapy. The control group and the group of poor responders showed no such change in activity pattern. In addition to physical activity, we also measured the children's endurance time on a treadmill test. Good responders showed improved endurance time after a year of growth hormone treatment, while poor responders and controls showed no such change in endurance time. These effects on activity patterns could, however, not be used to predict the children's response to growth hormone therapy.

By contrast, changes in body composition were found to have a good predictive value for the effect of growth hormone therapy on the children's growth. Body composition was measured using the deuterium dilution method, and expressed as total body water (TBW). Changes in TBW were divided by the square of the child's height, comparable to what is used in the body mass index $\left(\mathrm{BMI}=\right.$ weight $/$ height $\left.^{2}\right)$, in order to correct for height differences. Among good responders, changes in TBW/height ${ }^{2}$ during the first six weeks of growth hormone treatment were more than twice the standard deviation range of the controls. By contrast, poor responders could not be distinguished from controls. We concluded that changes in TBW/height ${ }^{2}$ after as little as six weeks predict the effect of growth hormone therapy on the child's growth.

The value of the present study is that six weeks of trial therapy are enough to reliably predict the long-term effect of growth hormone treatment, using a cheap test, which represents no great burden to the patient. The short trial period not only means a greatly reduced burden to the child, but can also have a considerable cost-saving effect. 


\section{SAMENVATTING}

In de geneeskunde worden dikwijls kinderen gepresenteerd met een vermeende groeistoornis. Om te beoordelen of daarvan ook werkelijk sprake is worden de volgende criteria gehanteerd:

- de lengte van het kind ligt meer dan 2.5 standaard deviaties onder de gemiddelde lengte van de referentiepopulatie waartoe het kind behoort;

- de lengte van het kind ligt meer dan 1.3 standaard deviaties onder de verwachte lengte op basis van de ouderlengte (target height);

- de lengteafbuiging in één jaar is groter dan 0.25 standaard deviaties.

Indien de lengtegroei van een kind aan een van deze criteria voldoet, wordt onderzoek verricht naar onderliggende pathologie. Een van de oorzaken kan groeihormoon(GH)deficiëntie zijn. De belangrijkste test om een dergelijke deficiëntie aan te tonen is een $\mathrm{GH}$ stimulatietest, waarbij een stijging van de serum $\mathrm{GH}$-concentratie boven $20 \mathrm{mU} / \mathrm{l}$ als normaal wordt beschouwd. Bij een geringere stijging, tijdens tenminste twee testen, komt het kind in principe in aanmerking voor een groeihormoon-behandeling. Echter, de diagnostische waarde van groeihormoontesten is aan veel kritiek onderhevig.

Omdat $\mathrm{GH}$ pulsatiel wordt uitgescheiden kan een enkelvoudige bepaling van de serumconcentratie niet gebruikt worden om een verminderde groeihormoonsecretie vast te stellen. Daarom wordt gebruik gemaakt van groeihormoon-stimulatietesten, waarbij het resultaat echter grote intra- en interindividuele verschillen kan vertonen op basis van het gebruikte agens als stimulator. Daarnaast is harmonisatie van laboratoria noodzakelijk om verschillen in uitslag op analytisch niveau uit te sluiten.

Zoals geldt voor iedere medische interventie is het resultaat het beste bewijs voor een effect. Anthropometrisch is het effect van groeihormoon pas betrouwbaar vast te stellen na een behandeling van tenminste 6 maar bij voorkeur 12 maanden. Omdat een groeihormoonbehandeling dagelijkse injecties met zich meebrengt en een dure behandeling is, is het wenselijk de effectiviteit al op kortere termijn vast te kunnen stellen.

Naast een effect op de groei heeft groeihormoon, al snel na de start van de behandeling, een effect op het metabolisme. De huidige studie is uitgevoerd om te onderzoeken of veranderingen in metabolisme, weerspiegeld in energiegebruik en lichaamssamenstelling, een voorspellingsmaat zijn voor het effect van groeihormoon op de groei.

De grootste component van het totale energiegebruik (TDEE= total daily energy expenditure), is de hoeveelheid energie die in rust wordt gebruikt, ook wel het basaal metabolisme genoemd. De hoeveelheid energie die aan fysieke activiteit wordt besteed is de meest variable component van het TDEE. De gouden standaard om het TDEE te meten is de tweevoudig gemerkt water methode. Wanneer naast het TDEE het basaal metabolisme wordt gemeten, kan de energie die wordt besteed aan fysieke activiteit uitgedrukt als PAL (physical activity level = fysieke activiteiten niveau) en AEE (activity related energy expenditure $=$ activiteit gerelateerde energie) worden bepaald. 
Teneinde te komen tot normaalwaarden van activiteit in relatie tot leeftijd werden de gegevens van 17 studies, waarin de tweevoudig gemerkt water methode was gebruikt, geanalyseerd. De hoeveelheid energie besteed aan fysieke activiteit, uitgedrukt als PAL en AEE, bleek te stijgen met de leeftijd. Omdat er geen relatie werd gevonden tussen leeftijd en $\mathrm{AEE} /$ gewicht wordt de stijging in de hoeveelheid energie die aan activiteit wordt besteed, waarschijnlijk veroorzaakt door een stijging in gewicht.

Activiteitenpatronen van kinderen werden gemeten met de Tracmor2. Tracmor2 is een versnellingsopnemer die het voorkomen en de intensiteit van beweging registreert. Activiteiten werden onderverdeeld in categorieën van lage (zitten), middelmatige (wandelen) en hoge (rennen) intensiteit. Deze studie toonde aan dat kinderen relatief meer tijd besteden aan activiteiten met een hoge intensiteit in vergelijking met volwassenen, waarschijnlijk omdat hun dit minder energie kost vanwege hun lagere lichaamsgewicht. Ook bleken PAL-waarden gerelateerd aan het percentage van de tijd dat werd besteed aan lage- en hoge- intensiteit activiteiten.

Het activiteitenpatroon van normaal groeiende kinderen werd vergeleken met dat van kinderen die een $\mathrm{GH}$-behandeling kregen. $\mathrm{Na}$ een jaar $\mathrm{GH}$-behandeling werden de kinderen onderverdeeld in kinderen die goed (verandering in lengte $>0.7$ standaardeviatie score (SDS)) en matig (verandering in lengte $<0.7$ SDS) hadden gereageerd op de GHbehandeling. Voor aanvang van de $\mathrm{GH}$-behandeling besteedden de kinderen die goed reageerden, relatief minder van de tijd dat ze actief waren aan hoge-intensiteit activiteiten dan normaal groeiende controles. $\mathrm{Na} 2$ weken behandeling met $\mathrm{GH}$ was dit verschil verdwenen. In de controlegroep en de groep met kinderen die matig reageerden, werd geen verandering in activiteit gevonden. Naast de fysieke activiteit werd het uithoudingsvermogen van de kinderen gemeten. De kinderen die goed reageerden, hielden een inspanningstest langer vol na een jaar behandeling. In de groep kinderen die een matige reactie lieten zien op de $\mathrm{GH}$-behandeling en de controlegroep werd geen verandering gevonden in de tijd dat ze een inspanningstest vol konden houden. Ondanks dat deze effecten op activiteit werden gevonden, konden deze effecten niet worden gebruikt om een reactie van GH op de groei te voorspelien.

Veranderingen in lichaamssamenstelling bleken een sterk voorspellende waarde te hebben voor het effect van $\mathrm{GH}$ op de groei. De lichaamssamenstelling werd gemeten met behulp van de deuterium-verdunningsmethode en uitgedrukt in totaal lichaamswater (TBW=total body water). De veranderingen in TBW werden gedeeld door lengte ${ }^{2}$, vergelijkbaar met de body mass index $\left(\mathrm{BMI}=\right.$ gewicht/lengte ${ }^{2}$ ), om te corrigeren voor verschillen in lengte. Veranderingen in TBW/lengte ${ }^{2}$ tijdens de eerste 6 weken van de $\mathrm{GH}$-behandeling, waren in de groep met kinderen die goed reageerden op de behandeling groter dan 2 keer de standaarddeviatie-grens van de controles. De kinderen die matig reageerden, konden echter niet worden onderscheiden van de controles. Daarom werd geconcludeerd dat al na 6 weken veranderingen in TBW/lengte ${ }^{2}$ een voorspellende waarde hebben op het effect van $\mathrm{GH}$ op de groei.

Het belang van deze studie is dat met behulp van een proefbehandeling van 6 weken op betrouwbare wijze, met behulp van een niet-belastende en goedkope methode, een 
uitspraak gedaan kan worden over het lange termijn effect van groeihormoon op de groei. Door de korte duur van de proefbehandeling betekent dit niet alleen een enorme lastenverlichting voor het kind, maar is dit ook economisch zeer aantrekkelijk. 


\section{DANKWOORD}

Bedankt Aniek, Ashley, Bart, Bo, Boris, Britt Cr, Britt Cl, Carlo, Carola, Chantalle, Chesny, Chiron, Christian, Cindy, Claudia, Corinne, Edmay, Floris, Guna, Hanneke, Harm, Inge, Iris, Jill, Johnny, Kelly B, Kelly K, Lars L, Lars B, Lieke, Lilian, Linda, Loes V, Loes vd W, Luc, Luuk, Marsha, Melanie, Merijn, Nadine, Nash, Natascha, Nina, Pien, Rene, Reneé, Rico, Rob L, Rob S, Roger, Roy, Sander, Sheila, Stefan, Thijs, Tim, Wesley, Wouter, Zarah. Jullie hebben erg je best gedaan tijdens de onderzoeken die in dit proefschrift staan beschreven.

Het project was geïnitieerd en stond onder de dagelijkse leiding van Willem-Jan Gerver. Willem-Jan, het was misschien niet zo slim om een "blondje" in dienst te nemen, maar gelukkig zijn we samen een heel eind gekomen. Misschien wordt het tijd om je standpunt over "domme blondjes" te herzien? Ik wil jou en Angèle (en Bor niet te vergeten) bedanken voor de leuke samenwerking, hopelijk kunnen we nog lang samen de afdeling kinderendocrinologie vormen!

De artikelen op het gebied van fysieke activiteit waren niet tot stand gekomen zonder de hulp van Prof, dr. Westerterp. Bedankt voor de goede suggesties voor het onderzoek en de snelle correcties van mijn manuscripten. Ook Prof. dr. Donckerwolcke wil ik bedanken voor het kritisch lezen van mijn proefschrift.

Zonder financiële steun van Eli Lilly Nederland was het onmogelijk geweest deze studie te realiseren. Maar naast financiële steun kon ik ook altijd op Jolanda Krijnen rekenen. Jolanda, ik wil je van harte bedanken voor je inzet voor mijn studie. Onze goede samenwerking resulteerde ook in een aantal geslaagde kindermiddagen voor mijn proefpersonen, hetgeen ik bijzonder heb gewaardeerd. Ik vind het erg fijn dat je samen met Marja mijn paranimf wilt zijn. Ik hoop alleen dat ik tijdens de promotie geen beroep op jullie hoef te doen.

Ook Ruud van Dael van Ferring wil ik bedanken voor de prettige samenwerking in de afgelopen 4 jaar.

De verpleging van B2 en de assistenten kindergeneeskunde zijn onmisbaar geweest door hun hulp bij de groeihormoon stimulatietesten. Ook wil ik graag alle collega's bedanken van de afdeling kindergeneeskunde voor hun belangstelling in de afgelopen 4 jaar voor mijn onderzoek. Hierbij wil ik het secretariaat en de poli-verpleegkundigen niet vergeten te bedanken voor hun hulp.

De praktische werkzaamheden van het onderzoek zijn naast de afdeling kindergeneeskunde uitgevoerd op de afdeling humane biologie. Hier heb ik prettig samengewerkt met alle AIO's vooral Annelies, Annemiek, Erwin, Guy, Marieke, Marleen en Mirjam. Ook kon ik altijd bij Loek en Paul terecht met vragen over de Tracmor, deuteriumanalyses of mijn Apple (die doet het soms ook niet, al is dat voor sommige Apple fans maar moeilijk te geloven). 
De afdeling fysiotherapie maakte het mogelijk de inspanningstesten uit te voeren. Hier werd ik altijd vriendelijk ontvangen en kreeg alle hulp die nodig was. Carlo, bedankt voor de hulp aan hoofdstuk 6 .

Meer mensen hebben een kritische blik geworpen op de artikelen zoals die in het proefschrift zijn opgenomen. Lambert Schuwirth, bedankt voor je verhelderende opmerkingen en opbouwende kritiek.

Prof. dr. Kuipers, bedankt dat je je wilde buigen over mijn groeihormoon-artikelen. Ik ben ook zeer vereerd dat je in mijn beoordelingscommissie plaats wilde nemen. Ook de overige leden van de beoordelingscommissie Prof. dr. Blanco, Prof. dr. Delemarre, Prof. dr. Drop en Dr. Schaper wil ik bedanken voor hun interesse en medewerking.

Drs. Klerkx wil ik bedanken voor alle suggesties op het gebied van de Engelse taal, waar ik meestal niet lang op hoefde te wachten.

De inhoud van een proefschrift mag dan belangrijk zijn, maar vormgeving is ook iets wat niet over het hoofd gezien mag worden. Hiervoor wil ik het Andi team bedanken en in het bijzonder Sandra. Hugo, het omslag is meer dan ik in gedachten had, ontzettend bedankt!! Natuurlijk was het niet zo mooi geworden zonder Sem, het "supermodel".

Familie en vrienden zijn natuurlijk in de afgelopen 4 jaar ook heel belangrijk geweest. Judith en Wendy. In 1993 zijn we samen in Maastricht begonnen. Dat betekent dus dat we dit jaar ons 10-jarig jubileum moeten vieren!!

Ook in het ziekenhuis en op de universiteit waren een aantal goede vrienden waarbij ik altijd terecht kon als het even niet liep zoals ik had gewild of om gezellig mee te lunchen. Ghislaine, Lilian, Lorraine, Marja, Mireille, Sander. Bedankt!! Het is jammer dat er maar twee paranimfen aanwezig mogen zijn tijdens de promotie.

Lieve Rien, een eervolle vermelding heb je meer dan verdiend! Bedankt dat je er voor me was en hopelijk nog heel lang zult zijn!! 


\section{CURRICULUM VITAE}

Marije Hoos werd geboren op 21 december 1973 te Moordrecht. In 1993 behaalde zij het VWO diploma aan het Gertrudis Lyceum te Roosendaal. In datzelfde jaar begon zij aan de studie Gezondheidswetenschappen aan de Universiteit Maastricht, met als afstudeerrichting Biologische Gezondheidkunde. De afstudeerstage werd uitgevoerd bij de afdeling diëtetiek en capaciteitsgroep kindergeneeskunde onder leiding van Dr. P.P. Forget en Prof. dr. K.R. Westerterp. Het onderzoek was gericht op het energiegebruik en eiwitmetabolisme van kinderen tijdens ziekte, $\mathrm{Ze}$ haalde haar doctoraalexamen in september 1998. In diezelfde maand startte zij als assistent in opleiding bij de capaciteitsgroep kindergeneeskunde onder leiding van Dr. W.J.M. Gerver, Prof. dr. R.A.M.G. Donckerwolcke en Prof. dr. K.R. Westerterp. 


\section{LIST OF PUBLICATIONS}

\section{Full Papers}

Van der Kuip M, Hoos MB, Forget PP, Westerterp KR, Gemke RJBJ, De Meer K. Energy expenditure in infants with congenital heart disease, including a meta-analysis. Acta Paediatrica (in press).

Van Waardenburg DA, Hoos MB, Deutz NEP, Jansen NJG, van Kreel BK, Vos GD, Wagenmakers AJ, Forget PP. Assessment of whole body protein metabolism in critically ill children: Can we use the $\left[{ }^{15} \mathrm{~N}\right]$ glycine single oral dose method? submitted.

Hoos MB, Gerver WJ, Kester AD, Westerterp KR. Physical activity levels in children and adolescents. Int J Obes 2003;27:605-609.

Hoos MB, Plasqui G, Gerver WJ, Westerterp KR. Physical activity level measured by doubly labeled water and accelerometry in children. Eur J Appl Physiol (in press).

Hoos MB, Kuipers H, Gerver WJM, Westerterp KR. Physical activity pattern of children assessed by tri-axial accelerometry. submitted.

Hoos MB, Westerterp KR, Kuipers H, Schuwirth L, Gerver WJM. Physical activity in children receiving growth hormone therapy as measured by tri-axial accelerometry. submitted.

Hoos MB, Theunissen C, Schuwirth L, Westerterp KR, Donckerwolcke RAMG, Gerver WJM. Endurance time and grip strength in children receiving growth hormone therapy. submitted.

Hoos MB, Westerterp KR, Gerver WJ. Short-term effects of growth hormone on body composition as a predictor of growth. J Clin Endocrinol Metab 2003;88(6):2569-2572.

\section{Abstracts}

Hoos MB, Van Waardenburg DA, Westerterp KR, Forget PP. Zijn de voorspellingsformules voor het energiegebruik in rust (REE, resting energy expenditure) van gezonde kinderen bruikbaar voor het voorspellen van de REE van zieke kinderen. Tijdschrift voor kindergeneeskunde, 1997:(suppl1);39.

Hoos MB, Gerver WJ, de Bruin R, Westerterp KR, Donckerwolcke RAMC. The value of the arginine provocation test for the diagnosis of growth hormone deficiency (GHD). Hormone Research, 2000:53(suppl2);33.

Hoos MB, Gerver WJ, Kester AD, Westerterp KR. Physical activity level and activity related energy expenditure in children and adolescents. Pediatric Research 2002:51(4pt2);211A.

Hoos MB, Van der Kuip M, Gerver WJM, Forget PP, De Meer K, Westerterp KR. Total daily energy expenditure in infants with a cardiac left to right shunt. Pediatric Research, 2002:51(4pt2);37A. 
Hoos MB, Theunissen C, Schuwirth L, Gerver WJM. The effect of growth hormone (GH) therapy in children on physical fitness. Hormone Research, 2002:58(suppl2);105.

Hoos MB, Westerterp KR, Schuwirth L, Gerver WJM. Physical activity in children receiving growth hormone therapy as measured by tri-axial accelerometry. Hormone Research, 2002:58(suppl2);156. 

